\title{
DESENVOLVIMENTO DE METODOLOGIA PARA ANÁLISE DOS COMPONENTES DE MEIOS DE CULTURA UTILIZADOS NA PRODUCূAO INDUSTRIAL DE VACINAS
}

\section{DAYSE MARIA DE MAGALHĀES FIGUEIREDO}

\author{
Orientador:Prof.Or. João Lǘcio de Azevedo
}

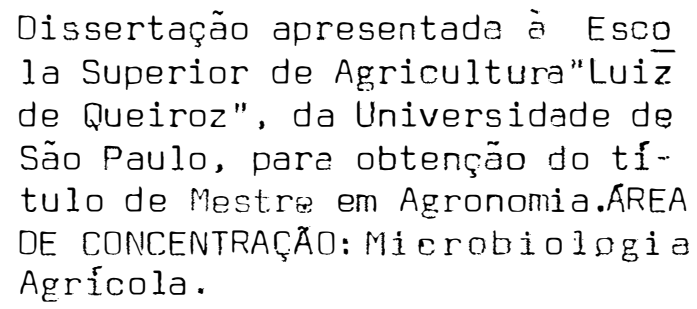

PIRACICABA

Estado de São Paulo - Brasil

Setembro -1988 
. 1 .

Para

Maria Lígia Magainães 


\section{AGRADECIMENTOS}

Expressamos nosso reconhecimento e agradecimen to a todos aqueles que contribuiram para a realização deste trabalho, especialmente:

- Prof. João Lücio de Azevedo, pela sua maneira simples, mas säbia, de aliar o conhecimento cientifico aos sentimentos de humanidade.

- Profa. Mari C.S. Armelin, pela iniciação nos conhecimentos de cultura de células de mamí feras e pela inestimável contribuição em tọ das as etapas deste trabalho.

- Prof. Marcos Luiz dos Mares Guia, Luciano Vilela, Josef Ernst Thiemann, Maria Alice de Magalhães Figueiredo.

- Prof. Hugo Armelin.

- Prof. Rogério Meneghini

- Maria Helena P.Fungaro, Itamar S. Melio, Lu zia D. Paccola, Genovefa Peisino, Vanda Lúcia N.L. Souza, Prof. Claudio L. Souza Junior. Profa. Aline Pizzirani-kleiner.

- Hélio Darci de Melo. Antónia Andrade Nascimeñ to, Edna I. P. Dutra de Morais.

- Professores e colegas dos Cursos de Pós-gra duação em Microbiologia Agricola e Genética e Melhoramento de Plantas. 
- Valiéa Nordesta S.A

- Biobrás - Bioquímica do Brasil S/A, pela upurlundada da dosurvatver agla projula no seu Departamento de Pesquisas.

- CAPES. 
LISTA DE TABELAS $\ldots \ldots \ldots \ldots \ldots \ldots \ldots \ldots \ldots \ldots$ vii

LISTA DE FIGURAS ................. ix

Lista de abreviaturas $\ldots \ldots \ldots \ldots \ldots \ldots \ldots \ldots \ldots \ldots \ldots \ldots \ldots$

RESUMO $\ldots \ldots \ldots \ldots \ldots \ldots \ldots \ldots \ldots \ldots \ldots \ldots \ldots \ldots \ldots \ldots \ldots \ldots \ldots \ldots \ldots$

SUMMARY $\ldots \ldots \ldots \ldots \ldots \ldots \ldots \ldots \ldots \ldots \ldots \ldots \ldots \ldots \ldots$

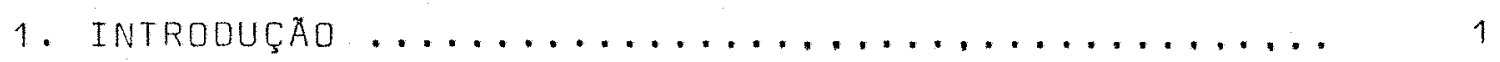

2. REVISÃ dE LITERATURA ................. 3

2.1. Cultura de células ................... 3

2.2. Cultura de células e a Virologia .......... 7

2.3. Meios de cultura e fatores peptidicos de crescimento $\ldots \ldots \ldots \ldots \ldots \ldots \ldots \ldots$

2.4. Cultura de células animais e produção de vacinas virais $\ldots \ldots \ldots \ldots \ldots \ldots \ldots$

2.5. Controle de qualidade em cultura de

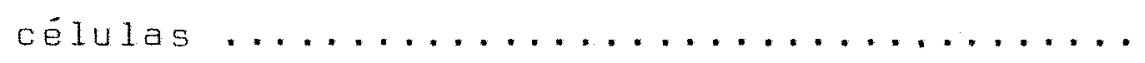

3. MAtertal E MEtodos .................... 25

3.1. Célula utilizada .................. 25

3.2. Meios de cultura e soluções ............ 25 
Página

3.2.1. Meios mínimos essenciais ......... 25

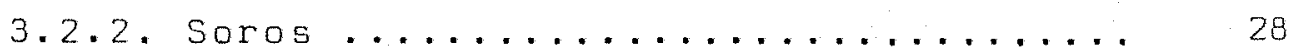

3.2.3. Caldo tripticaseina fosfato (CTF).... 28

3.2.4. Solução de hidrolisado de lactoalbumi

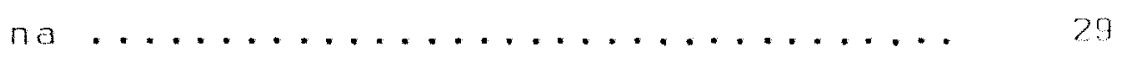

3.2.5. Solução de tripsina ............ 30

3.2.6. Solução salina fosfato pH 7,2 (PBS)... 30

3.2.7. Salução salina fosfato sem $\mathrm{Ca}^{2+}$ e $\mathrm{Mg}^{2+} \mathrm{pH} 7,2$ (PBSA) $\ldots \ldots \ldots \ldots \ldots \ldots \ldots$

3.2.8. Solução de azul de tripan ......... 31

3.2.9. Solução de vermel ho fenol a $1 \% \ldots 32$

3.2.10. Solução de cristal violeta ......... 32

3.3. Preparação de suspensão homogénea de célu-

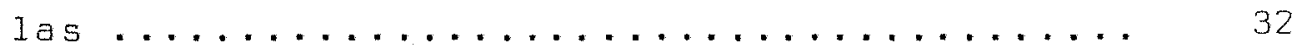

3.4. Manutenção e congelamento de estoques ..... 33

3.4.1. Preparo de estoques celulares ...... 33

3.4.2. Congelamento de células ......... 33

3.4.3. Descongelamento de células ........ 34

3.5. Crescimento celular em monocamada ....... 35

3.5.1. Determinação de $T_{D}$ e $D_{S}$ através de

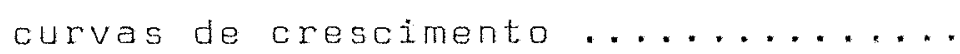


3.5.2. Coleta de cêlulas para contagem da

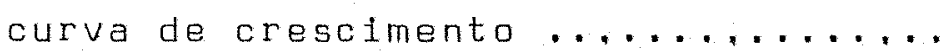

3.5.3. Determinação da eficiência de plaquea mento (E.P.) ...............

3.6. Crescimento celular em suspensão .........

3.6.1. Crescimento em frasco "spinner" ....

3.6.2. Crescimento em escala industrial ...

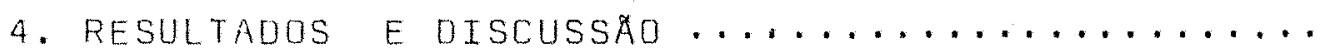

4.1. Anâlise do crescimento de células BHK-21 em monocamada $\ldots \ldots \ldots \ldots \ldots \ldots \ldots \ldots \ldots$

4.1.1. Eficiência de plaqueamento .......

4.1 .2 . Curvas de crescimento .........

4.2. Análise do crescimento de células BHK-21 em suspensão 1 fquida $\ldots \ldots \ldots \ldots \ldots \ldots \ldots$

4.2.1. Escala laboratorial ............

4.2.2. Escala industrial ............

4.3. Análise comparativa dos métodos de cultivo..

5. conclusúes $\ldots \ldots \ldots \ldots \ldots \ldots \ldots \ldots \ldots \ldots$ 
1 - Composição (mg/mI) dos meios mínimos essen-

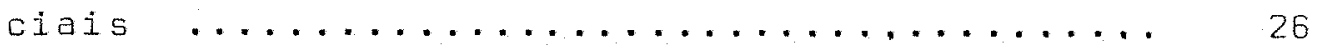

2 - Relação das amostras de caldo tripticaseina fosfato(Cff) 29

3 - Efeito do tipo de meio de cultura e soro na eficiéncia de plaqueamento de células BHK-21 cultivadas em melo mínimo + $3 \%$ soro +

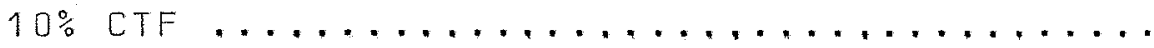

4 - Efeito de diferentes tipos de CTF na eficién cia de plaqueamento de células BHK-21 cultivadas em meio mínimo $+8 \%$ soro $+10 \%$ CTF....

5 - Resultados de eficiência de plaqueamento para células BHK-21 em diferentes ensaios, Células cultivadas em meio MEM + $8 \% \mathrm{sB}+10 \%$ CTF

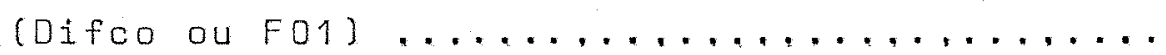

G - Valores de $T_{D}$ e $D_{S}$ para células BHK-21 crescendo em meio minimo $+8 \%$ SB $+10 \%$ CTF ......

7 - Valores de $T_{D}$ e $D_{S}$ para células BHK-21 crescendo em meio mínimo + $8 \%$ soro + 10\% CTFDifco $\ldots \ldots \ldots \ldots \ldots \ldots \ldots \ldots \ldots \ldots \ldots \ldots \ldots \ldots \ldots \ldots \ldots \ldots$ 
.0111.

8 - Valores de $T_{D}$ e $D_{S}$ para células BHK-21 crescendo em meio minimo + $8 \%$ soro $+10 \%$ CTF....

9 - Valores de $T_{D}$ e $D_{S}$ para células BHK-21 crescendo em meio mindmo $+8 \%$ SB $+10 \%$ CTF $\ldots \ldots$

10 - Valores de $T_{D}$ e $D_{S}$ para células BHK-21 crescendo em meio MGM + $8 \% \mathrm{SB}+10 \% \mathrm{CTF}$, suplemen

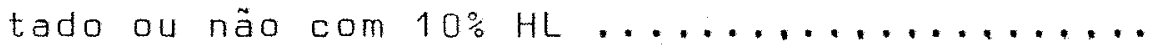


ix.

\section{LISTA DE FIGURAS}

Figura

Pëgina

1 - Atividade estimulatória de CTF sobre crescimento de células BHK-21 em meios DME e MEM suplementados com SB ............

2 - Atividade estimulatória de CTF sobre crescimento de células BHK-21 em melos MEM e MGM suplementados com SB ................. 50

3 - Efeito de soros bovino e fetal bovino sobre - crescimento de células BHK-21 mantidas em meio DME suplementado com CTF-Difco .......

4 - Efeito de soros bovino e fetal bovino sobre o crescimento de cêlulas BHK-21 mantidas em meio MEM suplementado com CTF-Difco $\ldots \ldots \ldots \ldots$

5 - Efeita de soros bovino e fetal bovino sobre o crescimento de células BHK-21 mantidas em meio MGM suplementado com CTF-Difco ..........

6 - Efeito da suplementação do meía DME com diferentes soros e CTFs na promoção de crescimento

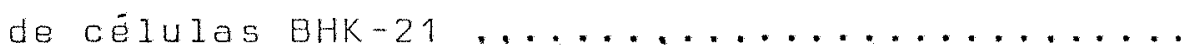


7 - Efeito da suplementação do meio MEM com diferentes soros e. CTFs na promoção de crescimen-

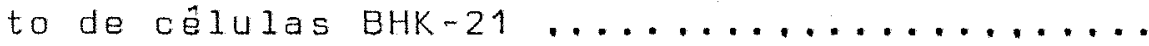

8 - Efeito da suplementação do meío MGM com diferentes soros e CTFs na promoção de crescimento de cëlulas BHK-21 ...............

9 - Efeito dos meios MEM e MGM na avaliaçaó da atividade mitogênica de diferentes amostras de CTF na promoção do crescimento de cêlulas BHK-

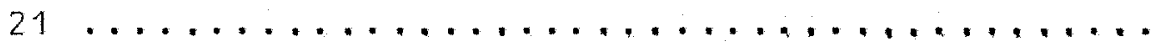

10 - Crescimento de cêlulas BHK-21 em suspensão 1 í quida (escala de laboratốrio) em meio MGM suplementado com $8 \%$ SB $+10 \%$ CTF $\ldots \ldots \ldots \ldots$

11 - Crescimento de células BHK-21 em suspensão If quida (escala industrial) em meio MGM suplementado com $8 \%$ SB $+10 \%$ CTF $\ldots \ldots \ldots \ldots \ldots$

12 - Crescimento de cêlulas BHK-21 em suspensão lí quida (escala industrial) em meio MGM suplementado com $8 \%$ SB $+10 \%$ CTF .......... 
.$\times i$.

Figura

Pègind

13 - Curvas de crescimento (monocamada) para célu las BHK-21 mantidas em meio MGM suplementado com $8 \%$ SB $+10 \%$ CTF e $10 \%$ HL $\ldots \ldots \ldots \ldots$

14 - Crescimento de células BHK-21 em suspensão Ifquida (escala de laboratório) en meio MGM $+8 \%$ SB + $10 \%$ CTF suplementado ou não com

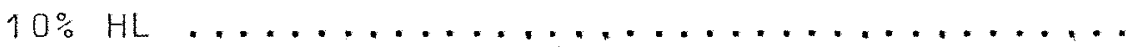

15 - Crescimento de cêlulas BHK-21 em suspensão Iíquida (escala industrial) em meio MGM $+8 \% \mathrm{SB}+10 \%$ CTF suplementado ou não com $10 \% H L, \ldots \ldots \ldots \ldots \ldots \ldots \ldots \ldots \ldots$ 


\section{LISTA DE ABREVIATURAS}

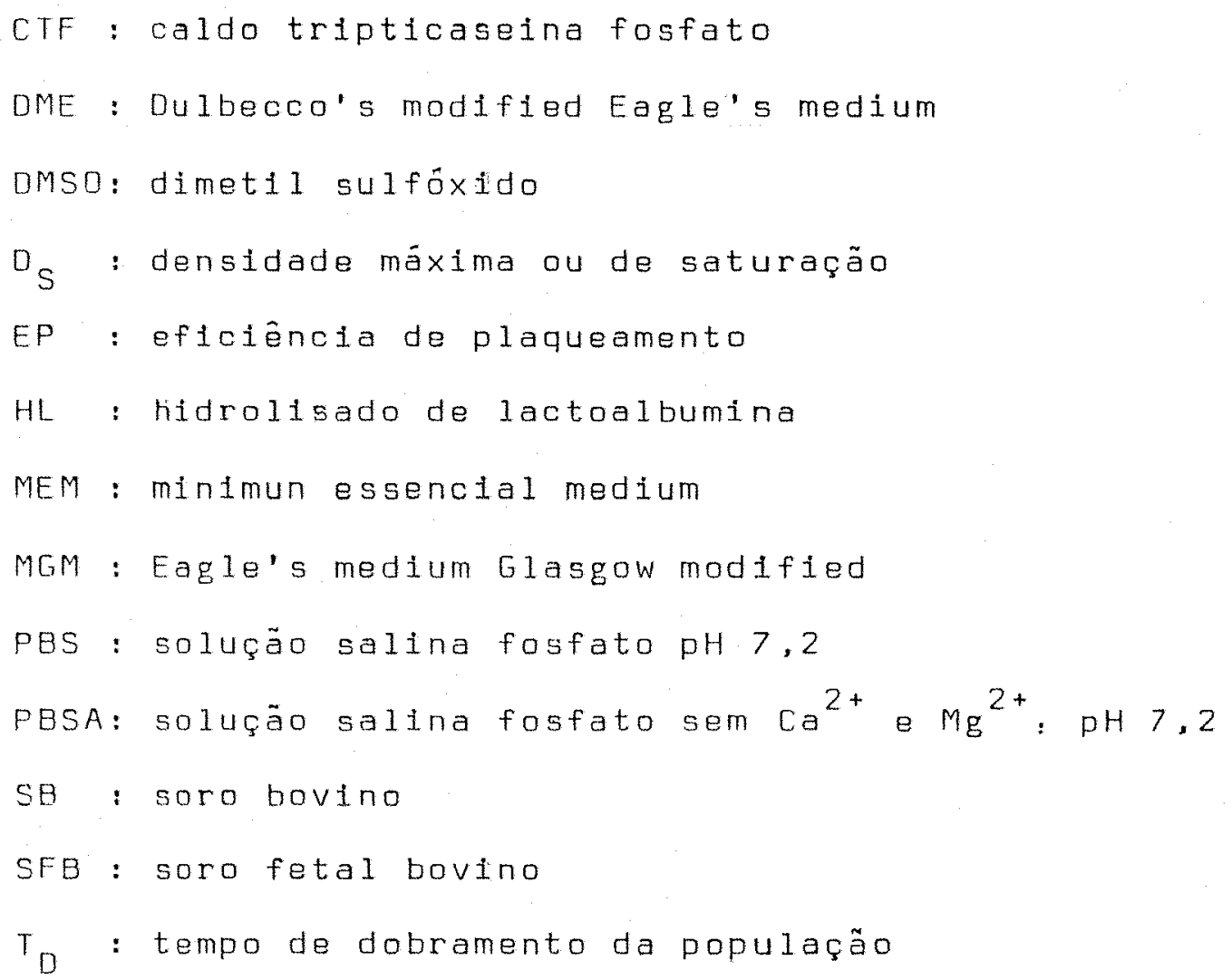




\section{DESENVOLVIMENTO DE METODOLOGTA PARA ANALISE DOS COMPONENTES DE MEIOS DE CULTURA UTILIZADOS NA PRODUÇAO \\ INUUSTRIAL DE VACINAS}

\section{Dayse Maria de Magalhães Figueiredo}

\section{Prof. Dr. Joäo Lücio de Azevedo \\ - oriantador.}

RESUMO

As vacinas virais, que representam os principais pro dutos obtidos a partir de cêlulas animais, continuam sendo produzidas com partículas virais obtidas a partir de culturas de células em grande escala.

A produção industrial da vacina contra febre aftosa envolve o crescimento, em suspensão líquida, de células BHK-21 ("baby hamster kidney cells") usadas como hospedeiras para multiplicação do vĩrus. Essas células são normal mente cultivadas em um meio nutritivo (Eagle's medium Glasgow modified - MGMI suplementado com soro animal e/ou outros suplementos quimicamente indefinidos como caldu tripticaseina fosfato (CTF) e hidrolisado de lactoalbumina. A função desses suplementos é estimular o crescimento das células para assegurar a manutenção contínua da cultura. 
o presente trabalho foi realizado com o objetivo de desenvolver uma metodologia prätica, pouco dispendio sa e em escala de laboratório, capaz de avaliar com rapidez e conflabilidade, a atividade promotora de crescimento dos meios de cultura utilizados na fabricação industrial de vacinas.

A determinação do tempo de dobramento ( $\left.T_{D}\right)$ e da densidade mäxima ou de saturação $\left(D_{S}\right)$ através de curvas de crescimento em monocamada mostrouase um mêtodo bastante eficaz para avaliar os nivels de atividade promotora de crescimento de diferentes meios de cultura, soros e CTF usados no cultivo de cêlulas BHK-21. Os resultados obtidos em monocamada se aplicam a células crescendo em suspensão líquida e reproduzem, com excelente aproximação, aqueles obtidos na indüstria.Além de permitir o estudo dos fatores promotores de crescimento, esta metodologia oferece perspectivas concretas no sentido da eliminação do soro no cultivo de células BHK-21, 
DEVELOPMENT OF A METHODOLOGYE FOR THE ANALYSIS OF CULTURE MFDTA COMPONENTS USED IN VACCINES' INDUSTRIAL PRODUCTION

\author{
Dayse Maria de Magalhães Figueiredo \\ Prof. Dr. João Lúcio de Azevedo \\ - Adviser -.
}

SUMMARY

Viral vaccines, the main product obtained from animal celis, have long been produced with viral particles obtained from large scale cell culture.

The industrial production of the foot-andmouth disease (FMOI vacoine tnvolves growth, in liquid suspension, of baby hamster kidney (BHK) cells used as the host for viral replication.Normally, these cells are cultured in nutrient medium (Eagle's medium Glasgow modified, MGM) supplemented with animal serum and/or other chemically undefined supplements Iike tryptose phosphate broth (TPB) and lactalbuin hydrolysate. These supplements stimulate cell growth and thus warrant continuous maintenance of the culture.

The objective of the present work was to develop a practical, unexpensive method to rapid and reproducibly 
$\times \vee i$

evaluate the growth promoting activity of culture media components utilized in the industrial production of vaccines,in laboratory scale.

Determination of the doubling time $\left(T_{D}\right)$ and saturation density $\left(D_{S}\right)$ through growth curves is shown to be an efficient and adequate method to evaluate the levels of growth promoting activity displayed by the different culture media, sera and TPBs utillzed In BHK-21 cells culture. The results obtained in monolayer are shown to directly apply to suspension cultures both in laboratory and in industrial scale. In addition to allowing the study of growth promoting factors, this methodology offers concrete perspectives for the complete elimination of serum as a medium supplement in BHK-21 cultures. 
1. INTRODUÇÃO

A origem da cultura de célula em grande escala empregada atualmente remanta há mais de vinte anos com a adaptação da célula BHK para crescimento em suspensão (CAPSTICK et alii, 1962 e TELLING e ELLSWORTH, 1965).Desde então, os princípios e processos desta tecnologia tém sido desenvolvidos e melhorados culminando com a produção de vaci nas virais (humanas e veterinárias) anticorpos monoclonais, in terferon, enzimas, hormonios, fatores peptídicos de crescimento e autros produtos biológicos relevantes (MIZRAHI, 1986b e RATAFIA, 1987b). As vacinas virais, que representam os prin cipais produtos obtidos a partir de células animais, continuam sendo produzidas com partículas virais obtidas a partir de culturas de células em grande escala (PHILLIPS et alii, 1985). A vacina contra febre aftosa, que afeta tanto bovinos como suinos, é considerada o mais importante produto obtido por cultura de células animais, com um consumo estimado em I,5 bilhão de doses anuals, sendo a América do Sul consumidora de 
5 miltiões de doses/and DOEL, 1985 e SPIER, 1982).

o meio de cultura utilizado para crescimento das células contém 50 ou mais componentes, sendo ainda suple mentado com soro animal e/ou peptonas.A produção dos melos de cultura e o controle de qualidade das matérias primas envolvidas neste processo representam não só notáveis desafios, mas também altos custos para os processos em grande escala.E de fundamental importância dispor de procedimentos präticos e pouco dispendiosos para testar os diversos componentes do meio.

o presente trabalho teve como objetivo desenvolver uma metodologia para avaliar com rapidez e conflabili dade, a atividade promotora de crescimento dos meios de cultura utilizados na fabricação de vacinas.o caldo tripticaseí na fosfato (CTF) que $\dot{e}$ um dos suplementos adicionados ao meio de cultura para crescimento da célula BHK-21 na produção de vacina anti-aftosa, serviu de instrumento para validar o método. o procedimento deve ser simples, de fácil execução, baixo custo e capaz de mimetizar as condiçães industriais, reproduzindo, em pequena escala, os resultados abtidos na indústria. 


\section{REVISÃO DE LITERATURA}

2.1. Cultura de cëlulas

A cultura de células iniciou-se nas primeiras décadas do século XX com a aceitação de idéia de que células pertencentes a animais superiores poderiam ser removidas do animal e colocadas para crescer e multiplicar "in vitro".Esta idéia foi comprovada com os experimentos de HARRISON (1907) que acompanhou a diferenciação de células de pedaços de tubo neural de rã, em sistema gata pendente de linfa de rã, demonstrando que a função normal continuava in vitro. Esta técnica foi aplicada a outras células de técidos animais homeotermos, usando plasma ou soro como meio paracrescimento (BURROWS, 1910; CARREL E BURROWS, 1910 e EBELING, 1913).

$$
\text { Para eliminar as limitações dos métodos até }
$$
então empregados (cultura em gota pendente) foi desenvolvida a técnica de cultura em frasco (CARREL, 1923) a qual permite 
cultivar maior quantidade de células aderidas a uma superfície adequada, o que facilita a renovação do meio. Pcsteriormente, com a intensificação das pesquisas sobre metabolismo e crescimento, houve necessidade de se criar um outro sistema, o "roller flask", que possibilita cultivar grande quantidade de células sobre uma superficie adequada ligual à do método anterior porém com grande economia de meio de cultura uma vez que as garrafas são mantidas numa plataforma giratória. onde a sunerfície celular é banhada constantemente, mas com pequeno volume de meio (GEY, 1933).

Um avanço importante foi a descoberta de méto dos para obtenção de suspensão de células viáveis. Trabalhos iniciais usavam tripsina para liberar as células víáis dos seus tecidos parentais (ROUS e JONES, 1916) para transferir células entre culturas de plasma (SIMMS e STILLMAN, 1937) e para separar epiderme (MEDAWAR, 1941). Somente com os trabaIhos de MOSCONA e MOSCONA (1952) foram definidas as técnicas de tripsinização de cultura de células, em meio sem $\mathrm{Ca}^{2+}$ e $\mathrm{Mg}^{2+}$, permitindo as suas aplicações no crescimento quantitativo das células (RINALDINI, 1954 e PUCK e MARCUS, 1955) e no preparo de monocamadas de células para a multiplicação de virus (DULBECCO, 1952 e YOUNGER, 1954).o estudo quantitativo do crescimento de células de mamíferos desenvolvido por PUCK e MARCUS (1955) e baseado no crescimento independente de cada célula de uma determinada população até formação de uma colónia macroscópica possibilitou não só estudar o cresctmen 
to, a genética, a fisiologia e a bioquímica celulares como tambëm a ação de drogas, vírus, radiações e outros agentes sobre as células.

Mais recentemente quelantes de $\mathrm{Ca}^{++}$(EDTA, por exemplo) passaram a ser usados ao lado de tripsina (ou mesmo substituindo-a). A grande vantagem consiste, naturalmente, em reduzir os efeitos deletérios da enzima que atua sobre qualquer proteína celular podendo levar a grande perda de viabilidade (GRIFFITHS, 1985a).

Os métodos desenvolvidos para o cultivo de cé lulas animais encontraram sua grande aplicação na produção de vacinas virais a partir de cëlulas que cresciam aderidas a uma superfície (TOLBERT, e FEDER, 1983). A adaptação das células BHK (baby hamster kidney) para crescimento em suspensão (CAPSTICK et alii, 1962) permitiu o escalonamento dasculturas celulares para os atuais sistemas de cultura em tanques de 8000 1, usados na produção de interferon (PHILLIPS et alii, $1985)$.

A tecnologia de cultura de células de mamíferos em grande escala tem apresentado um rápido desenvolvimen to nos ültimos anos.para as células que podem crescer em sus pensão têm sido adaptados os métodos usados nas fermentações microbianas (LYNN e ACTON, 1974 e ZWERNER et alii, 1981).As cé lulas que necessitam crescer aderidas a uma superfície também podem ser cultivadas em suspensão, usando-se partículas 
mlcrogóplcas ("microcarriers") como suportes para adesão das células (VAN WEZEL e VAN der VELDEN-de GROOT, 1978, SPIER 1980; TOLBERT e FEDER, 1983). Outros processos que têm sido desenvolvidos baseiam-se em técnicas de crescimento celular nas paredes de fibras ocas-"hollow fibers" (KNAZEK et alii, 1972 e kU et alii, 1981) e na microencapsulação de células (JARVIS E GRDINA, 1983 ).

o desenvolvimento das técnicas de hibridização de células somáticas (HARRIS e WATKINS, 1965 e OKADA e MURAYAMA, 1965) e a descoberta da possibilidade de manter con tinuamente em cultura uma célula que secreta anticorpo (KOHLER e MILSTEIN. 1975) permitiram a produção de anticorpos monoclonais em grande escala, através da cultura de células (BIRCH et ali1, 1985 a KARKARE et al11, 1985).

As implicações a consequências do uso das técnicas de DNA recombinante e hibridoma estão atualmente sob intensa investigação, principalmente a produção de muitas proteinas complexas de interesse farmacológico como antígenos virais, enzimas, hormōnios, ativador tissular de plasminogê n10, interferon (ARATHOON e BIRCH, 1986; MIZRAHI, 1986a, SPIER, 1988 e SPIER a HORAUD, 1985). A complexidade bioquimica desses materiais impede a sua sintese nos sistemas microbianos recombinantes, que são incapazes de efetuar as glicosilações especificas, as corretas ligações disulfeto e a configuração tridimensional da molécula. No entanto as células animais, além de traduzir e sintetizar corretamente as protelnas clo 
nadas, também secretam-nas para o meio de cultura, o que facilita os processos de purificação e isolamento desses produ tos (WOOd et alii, 1984 e BERMAN et alii, 1985). Assim, é esperado que na pröxima década a cultura de células animais assumirá maior importância na produção de fármacos.

2.2. Cultura de células e a Virologia

- impacto da cultura de células na virologia foi enorme, levando ao desenvolvimento não só de têcnicas analiticas como também a possibilidade de produzir vírus in vitro.o crescimento de vírus em cultura de células foi tenta do inicialmente por STEINHARDT et alii (1913) e PARKER E NYE (1925).Posteriormente, MAITLAND e MAITLAND (1928) usaram a cultura em frasco para crescimento do vírus de Vaccinia.Gran de impulso foi dado pelos trabal hos de ENDERS et alii (1949) mostrando o crescimento da Iinhagem Lansing de poliovírus em cultura de células e o emprego do efeito citopático apresentado pelas células como um indicador de crescimento do vírus. A utilização da cultura de células para a multiplicação de vírus prosseguiu com o desenvolvimento do ensaio de placa (DulbeCCo, 1952 e Dulbecco e FreEman, 1959) e do ensaio de fOCo (TEMIN e RUBIN, 1958).

A produção do poliovírus em cultura de células e o sistema de "roller flask" para crescimento de células 
permitiram o aparecimento de diversos processos para produção de vacinas à partir de culturas em monocamada como as vacinos contra adenovirus (HILLEMAN, 1958) febre aftosa (PATTYet alii, 1960 e MOWAT a CHAPMAN, 1962), caxumba (BUYNACK e HILLEMAN, 1966), sarampo (HILLEMAN et ali1, 1968) e rubëola(BUYNACK et al1i, 1968).

2.3. Meios de cultura e fatores peptídicos de crescimento

No perído inicial dos trabalhos com cultura de tecidos quando plasma era usado como meio de crescimento LEWIS e LEWIS (1912) mantinham os tecidos em soluções galinas. Estes autores verificaram então que a sobrevivência das cólulas aumentava pela suplementação da solução salina com glicose e aminoácidos. Essas observações sugeriam a importância de se trabalhar com meios de composiçäo conhecida.Entretanto a descoberta de que a adição de extrato de embrião aumentava o crescimento dos tecidos em plasma (CARREL, 1913) retardou os estudos para desenvolvimento de meios de composi ção definida.

o primeiro meio de cultura definido foi desen volvido por WHITE (1946) sendo composto de glicose, sais inor gànicos, aminoácidos, vitaminas e hormónios, como insulina e tiroxina, levando em consideração também fatores físico-qué micos como osmolaridade, pH e composicão gasosa.este meio permitia uma sobrevivencia prolongada, mas não a proliferação 
dos tecidos.logo depois, foi descrito o meio 199 (MORGAN et alii, 1950) mais complexo que o anterior, porém permitindo apenas a manutenção da célula.

Com o estabelecimento de células em cultura es pecificamente das linhagens L (SANFORD et alii, 1948) e HeLa (SCHERER et al11, 1953) tornou-se possivel trabalhar com uma população celular uniforme e reprodutível, o que permitiu um rápldo avanco na formulaçáo dos maios definidos. A década de 50 foi marcada pelo grande nümero de estudos visando estabelecer os requisitos nutricionais minimos para crescimento de várias linhagens de células de mamíferosifol demonstrado que, além da presença de saro, as células Hela e L necessita vam de 13 aminoácidos larginina, cistina, fenilalanina, glutamina, histidina, isoleucina, leucina, lisina, metionina,ti rosina, treonina, triptofano e valina) 8 vitaminas (ácido fó 1ico, äcido pantoténico, biotina, inositol, nicotinamida, p1 ridoxal, tiamina e riboflavina) 6 fons inorgánicos ( $\mathrm{Na}^{+}, \mathrm{K}^{+}$, $\mathrm{Mg}^{++}, \mathrm{Ca}^{++}, \mathrm{Cl}^{-}$e $\mathrm{H}_{2} \mathrm{PO}_{4}^{-}$) e glicose (EAGLE, 1955a; EAGLE, 1955b; EAGLE, 1959 e EAGLE et al1i, 1957). Esses dados formaram a base do clásstoo meto mínimo essenctal (MEM) de Eagle, usado até hoje.

Em seguida surgiram inümeros meios de cultura formulados com vários componentes e visando melhorar o crescimento de várias cëlulas, mas sem a preocupação de identifi car os seus requerimentos especificos (RIZZINo et alii,1979).

o uso de meios definidos possibilitou a iden- 
tificação de outros requerimentos nutricionais como ácidos graxos (ácido linoleico) poliaminas (putrescina) e elementos traço (HAM, 1963; HAM, 1965; HAM e MCKEEHAN, 1979 e HIGUCHI, $1973)$.

Entretanto, o soro permanacia como um componen te essencial para o crescimento da maioria das células.0 soro é uma mistura complexa, com alguns dos seus companentes pouco ou nada caracterizados e outros cujas concentraçõas va riam drasticamente entre diferentes partidas.Värios problemas associados ao uso a à natureza complexa e indefinida do soro têm sido reconhecidos.o seu custo ä multa a lavado, além de apresentar uma escassez periódica sazonal a um suprimento limitado para produção em grande escala.Uma das grandes obje Ções ao uso do soro no preparo de produtos colulares para uso humaro é o seu potencial como fonte de contaminação por agentes infecciosos como vírus, bactërias a micoplasmas. Outro problema é sua possivel interfaréncia na purificação de determinados produtos, como $\dot{\theta}$ o caso das imunoglobulinas nos produtos imunológicos (GRIFFITHS, 1986a e LAMBERT e BIRCH, $1985)$.

Diversas tentativas foram feitas para eliminar a necessidade de soro no melo de cultura através da adap tação de Iinhagens celulares ao meio sem soro (KATSUTA e TAKAOKA, 1973) ou da purificação dos seus componentes ativos (FISHER et ali1, 1958 e HIGUCHI, 1973). Entretanto a complexi dade do soro, as baixas concentrações das substáncias ativas 
e as alterações apresentadas pelas células selecionadas não favoreceram a aplicação prática desses experimentos.

o desenvolvimento de um método para otimizar os meios definidos e eliminar as quantidades de soro, através de um cuidadoso ajuste da composição e balanço dos nutrientes (MCKEEHAN et alii, 1977; HAM e MCKEEHAN, 1979 e HAM, $1982)$ mostrou-se de grande utilidade e importáncia para os estudos de crescimento de células em meio sem soro.

0 desenvolvimento de linhagens celulares hormōnio-dependentes (ARMELIN, 1975) levou à hipótese de que uma das principais funções do soro seria fornecer hormónios e fatores de crescimento necessärios ao crescimento dascéluIas (ARMELIN, 1973; ARMELIN, 1975; SATO, 1975 a MATHER a SATO, 1979). Esta hipótese fol Intclalmente comprovada pelo crescimento da célula $\mathrm{GH}_{3}$, de pituitäria, em meio sem soro suplementado cam hormónios, fatores de crescimanto o trancferrina (HAYASHI E SATO, 1976 ).

Alèm dos hormónios, o. soro também fornece: a) proteinas de transporte, como transferrina, que facilitam a entrada nas células de nutrientes e minerais exigidos por estas; b) outras proteínas, tais como albumina e fetuina,que podem detoxificar o meio ao se Iigarem a metais tóxicos, estabilizar substancias lábeis e atuar como substáncia tamponante (GUTLBERT e ISCOVE, 1976; ISCOVE e MELCHERS, 1978 e RUOLAND et a 111,1977 ); c) fatores proteicos como fibronect 1 
na, necessários à adesão e espraiamento das células na superfície de crescimento (HOLMES, 1967 ; HöOK et alii, 1977 e YAMADA e OLDEN, 1978); d) nutrientes de baixo peso molecular tais como aminoäcidos, vitaminas, minerais, ausentes no meio basal ou presentes em concentrações sub-ótimas (HOLLEY, 1974 e HoLleY e KIERNAN, 1974); e) inibidores de protease que inativam a trip sina utilizada para remover as células da superfíle ou para dissociar os tecidos (HAM e MoKEEHAN, 1979), fl fatores proteicos chamados fatores de crescimento como PDGF. IGFs, etc (ver mais adiante).

o conhecimento das funçães do soro na cultura de células e o desenvolvimento de uma metodologia adequada para se estudar sua substituição permitiram a formulação de meios que mantêm o crescimento de inúmeras linhagens celulares na auséncia ou em baixa concentração de soro, suplementados com hormónios, fatores de crescimento e proteínas de transpor te (BARNES e SATO, 1980; BOTTENSTEIN et alii, 1979 e BOTTENSTEIN, 1983).o primeiro meio sem soro foi descrito para a célula $\mathrm{GH}_{3}$, de pituitäria de rato, sendo composto de sels hormônios, trans ferrina, selénio e cadmio (HAYASHI ot alit, 1978 e HAYASHI e SATO, 1976). Em seguida surgiram inúmeros meios definidos sem soro, otimizados para a proliferação especifica de determinadas células, originadas de diferentes tecidos, como: Hela (HUTCHINGS e SATO, 1978 e WU E SATO, 1978); MZR (MATHER E SATO, 1979); B104 (BOTTENSTEIN E SATO, 1979 \& BOTTENSTEIN 8 SATO, 1980); BHK (MACIAG et alii, 1980), SV40-BaIb/3T3 (ROCKWELL 
et alii, 1980); FLOW 2000 (WALTHALL \& HAM, 1981), WI 38(BETTGER et alii, 1981); 3T3 (SHIPLEY e HAM, 1983). A principal conclusão destes trabalhos fol que cada tipo de célula requer uma combinação especifica dos fatores do soro permitindo descrever os papétis desses fatores na estimulação do crescimento dessas células.

0 cultivo de células em meios hormonalmente de finidos tem demongtrado que mültiplos fatores de crescimento controlam a proliferação celular (ARMELIN, 1973; ARMELIN, 1975; PLEQGER et al11, 1977 a BARNES e SATO, 1980J.Esses fatores de crescimento estimulam a sintese de ONA de células em repou so $\left(G_{0}\right)$ e impedem que cẻlulas em ativo crescimento entrem em repouso, mas são insuficientes para estimular a proliferação de culturas mantidas na auséncia do fatores nutricionalo adequa dos (CHERINGTON, 1984). Além disso, um ünico fator não é suficiente para induzir mäxima síntese de DNA em células bloqueadas em $G_{u}$ por remoção de soro do meio de cultura.A necessidade de uma combinação de fatores foi relatada pela primeira vez por ARMELIN (1973) ao observar que a combinação de suplementos nutricionais, hidrocortisona, insulina e um extrato de pituitária que provavelmente seria FGF-"fibroblast growth factor") estimulava a sintese de DNA e a proliferação das células 3 T 3 mais do que qualquer um dos fatores isoladamente. Este trabalho, ao introduzir um ensaio de atividade biológica relativamente simples e eficiente, que consiste em medir a es timulação de entrada em fase $S$ de células $3 T 3$ em repouso les 
tado $G_{0}$, permitiu isolar e purificar FGF e outros fatores de crescimento.

FGF foi encontrado em hipófises bovinas (ARMELIN, 1973) e cérebro bovino (GOSPODAROWICZ, 1974). POGF ("plate lat" derived growth factor") um polipeptideo liberado por plaquetas humanas durante a coagulação, tem mostrado ação mitogênica para fibroblastos (ROSS et alii, 1974; KOHLER e LIPTON, 1974), assim como o fator de crescimento epitelial, EGF - "epidermal growth factor" (COHEN, 1962). Outros polipeptideos com atividade de fator de crescimento para células em cultura foram isolados: NGF-"nerve growth factor" (LEVI-MONTALCINIE ANGELETTI, 1968). MSA-"multiplication stimulating activity" (DULfK e TEMIN, 1973), OGF-"ovarian growth factor" (GOSPODAROWICZ et alii, 1974), somatomedinas ou fatores de sulfatação e de timidina (VAN WYCK et aIII, 1971 e HALL e UTHNE, 1971), NSILA -"non supressible insulin like activity" ou IGF-I e IGF-II - "insulinlike growth factors I e II" (RINDERKNECHT \& HUMBEL, 1976 e FROESCH et alii, 1979). TGFs $\alpha$ e $\beta$ - "transforming growth factor" (SPORN E TODARO, 1980 ).

- estudo dos fatores de crescimento proporcionou grandes avanços na anälise do ciclo celular.A ação de fatores como fGF e PDGF leva células balb-3T3 que estão em repouso $\left(G_{0}\right)$ a se comprometer com um programa de transcrição que culmina com a divisão celular. De acordo com alguns autores (PLEDGER et alii, 1977 e STILES et alii, 1979) uma sequência ordenada 
de eventos ocorre dependendo da presença de dois tipos de controladores representados por PDGF (presente apenas no soro) e IGFs (presentes no soro e no plasma).PDGF tornaria as células "competentes" para a divisão celular, que só ocorrerá com o suprimento dos chamados fatores de progressão EGF e IGFs. POGF e FGF são,portanto; considerados fatores de competéncia e EGF e IGF fatores de progressão, para células 3 T3 (Leof et a Iii, 19821 .

2.4. Cultura de células animais e produção de vacinas virais

Há dois grandes grupos de produtos originados de células animais : vacinas virais e proteínas biologicamente ativas.o número de proteínas purificadas produzidas comercialmente é limitado. Entre estas encontram-se $\propto$ e $\beta$ interferon e anticorpos monoclonais, seguidos pela recente produção do ativador tissular de plasminogénio (CARTWRIGHT,1987).

A necessidade de vacinas virais conduziu a cul tura de células para os processos de grande escala iniciados com a produção da vacina Salk contra a poliomielite, em 1954. As principais vacinas humanas produzidas a partir de células animais são Salk e Sabin (poliomielite), sarampo, cachumba,rü béola, raiva, febre amarela e influenza (GRIFfiths, 1985b). 
o nümero de vacinas veterinärias é muito maior, destacando-se a vacina anti-aftosa, que representa o maior pro duto obtido por cultura de células antmals : 1.5 bilhão de doces por ano, que corresponde a mais de 2 milhães de litros de meio de cultura (CARTWRIGHT, 1987).

Inicialmente as vacinas para febre aftosa eram produzidas a partir de vírus cultivado em fragmento de epité lio lingual de bovino, mantido temporariamente "in vitro" (FRENKEL, 1947 e CARTWRIGHT et alii, 1957) 4Esse mátodo foi suplantado pelo uso de células de rim bovino cultivadas "In vitro" (SELLERS, 1955; PATTY et alii, 1960 e PLEDGER, 1961) e posteriormente pelo estabelecimento de linhagens celulares altamente sensiveis eo vírus da febre aftosa : cêlula BHK (MOWATT e CHAPMAN, 1962) e célula IB-RS-2 (CASTRO, 1964).

A célula BHK-21 ("baby hamster k1dney") fol isolada de culturas de rim de hamster de um dia de idade cultivadas em monocamada no meio basal de Eagle modificado (contendo o dobro da concentração normal de aminoácidos e vitaminas) adicionado de $10 \%$ de soro bovino e $10 \%$ de caldo tripticaseina fosfato (MACPHERSON e STOKER, 1962) no qual apresentam rápido crescimento associado à formação de uma densa camada de células. A partir dessas células foram cultivados $\theta$ clones; sendo que um deles, designado de BHK-21/13 (ou C13)foi bastante estudado tornando-se o estoque padrão distribuido pe lo laboratório da Universidade de Glasgow (STOKER e MACPHERSON, 
1964). As células BHK-21 são alongadas e crescem com uma orien tação paralela, como fibroblastos. Durante o. crescimento logarítmico, no melo descrito acima, apresentam um tempo de dobra mento médio de doze horas.o crescimento continua mesmo depois de atingir a confluência, o que resulta numa densidade de saturação muito elevada, aproximadamente $10^{6}$ células por $\mathrm{cm}^{2}$ de SUPerffCie (MACPHERSON, 1963 e STOKER E MACPHERSON, 1964).

Os sistemas de cultura desenvolvidos para as células de rim bovino e BHK eram baseados no crescimento de células aderidas à superfície de frascos de vidro (monocamadas estacionários ou rotativos.uma mudança marcante foi introduzida pela adaptação dascélulas BHK-21 para crescimento em suspensão (CAPSTICK et ali1, 1982).0s experimentos para verifí car as mudanças ocorridas durante esse processo de adaptação mostraram uma alteração permanente nas caracteristicas de cres cimento em monocamada, o desenvolvimento de células gigantes multinucleadas e um aumento na velocidade de desenvolvimento de tumor (CAPSTICK et alii, 1966).

A utilização da célula BHK-21 na produção comercial de vacina anti-aftosa incentivou a pesquisa para aumentar os rendimentos celulares nas culturas em suspensão (TELLING e ELSWORTH, 1965 e TELLING, 1969). A complementação do meio com hidrolisado de lactoalbumina associada ao aumento da concentração de outros componentes permitiu dobrar os rendimentos até então conseguidos (RADLETT et ali1, 1971). 
TELLING e RADLETT (1971) demonstraram a dependência do crescimento de células animais em relação a diferen tes parámetros químicos e ffsicos a ao controle do pH da cultura por injeção de $\mathrm{CO}_{2}$ e ar.Posteriormente determinaram um valor ótimo para $\mathrm{pO}_{2} \mathrm{em} 80 \mathrm{~mm} \mathrm{Hg}$ para as células BHK e observaram uma redução na densidade celular mäxima na velocidade de crescimento em outros valores de $\mathrm{pO}_{2}$ (RADLETT et alii, 1972).

Apesar da produção do vírus da febre aftosa em monocamada de células BHK não ser um procedimento comum nas operações industriais, existem trés processos que usam este sistema de produção. Um deles usa "roller bottles" para crescimento das células, sendo necessário um nümero muito grande de garrafas para a produção industrial (SPIER, 1983) Ds outros sistemas são processos unitários, onde o aumento da produtivi dade decorre do aumento do tamanho do equipamento e não do nümero de unidades.o primeiro deles foi descrito por SPIER e WHITESIDE (1976a e 1976b) sendo baseado no crescimento das células BHK na superfície de esferas de vidro de $3 \mathrm{~mm}$ mostrando o crescimento de quatro inhagens do vírus da febre aftosa nessas células.Posteriormente ésse processo foi escalonado para 100 litros de meio (WHITESIDE e SPIER, 1981). D segundo sistema baseia-se no crescimento das células na superfície de partículas microscópicas ("microcarriers") com escalonamento para 150-170 litros (MEIGNIER, 1979 e MEIGNIER et alii, 1981).

Os trabalhos de MIZRAHI e AVIHOO (1976) mostra ram que hidrolisado de lactoalbumina e caldo triptose 
fosfato são as principais fontes de aminoácidos para o crescimento das células BHK. Na tentativa de diminuir o custo do meio de cultura procurou-se substituir o soro por peptonas com bons resultados da crescimento das células eHK e de virus, seja vírus da estomatite vesicular (KEAY, 1975) ou vírus da encefalomiocardite (MIZRAHI, 1977). TOMEI e ISSEL (1975) mostraram a produção do vírus da febre aftosa em células BHK cultí vadas em meio sem soro com rendimentos comparáveis aos obtidos cam. células que crescem em meio suplementado com soro.

2.5 Controle de qualidade em cultura de células

As células representam a base do processo de producäo de vaciras e autros produtos de interesse. A reprodutibilidade dos parametros de crescimento e produtividade celulares destaca-se como sendo o ponto mais critico dentro deste processo, o que requer grandes cuidados na manutenção e mani pulação. das células.De, grande importáncia também é a disponjhilidade de um suprimento constante de células bem caracterizadas e com qualidade padronizada empregando-se a método de estocarsm en tanques de nitrogénio líquido (SCHEIRER, 1997).

E de fundamental importāncia levar em consideração os seguintes fatores : a) água; b) matérias-primas; c) meio de cultura; d) soro e e) esterilidade. 
A ăgua utilizada em cultura de células deve sor altamente purificada emprepando-se destilador de vidrolágua bi ou tri-destiladal ou outros sistemas equivalentes, como osmose-reversa. A água usada na formulaça de meios de cultura deve ser analisada periodicamente para verificar a au sência de pirogênio (PUMPER, 1973 e MCLIMANS, 1979).

As substânoias químicas usadas devem ser da me Ihor qualidade e devem conter um certificado de análise para cada Iote.0s procedimentos usados no controle de qualidade das matérias-primas devem ser altamente padronizados, além de mimetizar as condições usadas na produção (MORTON e MORGAN, 1973 e SPIER, 1982).

As funcõos de um meio para crescimento de célu las podem ser definidas como : manutenção das condiçães físico-químicas desejadas e fornecimento dos nutrientes para a sintese de biomassa celulare de produbos.lontro deste conceito, os parámetros básicos de controle de qualidade para meios de cultura são fatores físico-quimicos (pH e osmolaridade) es terilidade do meio, capacidade promotora de crescimento celu Iar e formação de produtos (LAMBERT e BIRCH, 1985).

Diferentes tipos celulares exigem distintos va lores de pH dentro da faixa 3,9 - 7,8 para atingirem um nível ótimo de crescimento. No inicio da cultura o pH deve estar próximo de 7,4; não devendo cair abaixo de 7,0 durante o cultivo. Normalmente um pH abaixo de 6,8 è inibitório para o crescimen 
to da célula (EALGE, 1973). Tradicionalmente o meio de cultura de células é tamponado pelo sistema $C 0_{2}$-bicarbonato, anádogo ao do sangue. É possivel melhorar a capacidade tamponante do meio e estabilizar o pH usando um tampão orgãnico, como Hepes (10-20 mM), juntamente com o bicarbonato ou substituindoro (EAGLE, 1971). Além disso, a medida final do pH deve ser efetuada a $37^{\circ} \mathrm{C}$, após esterilização, dentro das condiçóas usadas na prática, incluindo o equilíbrio com a correta mistura de gäs (LAMBERT \& BIRCH, 1985).

Osmolaridade é a medida da atividade osmótica total, que é fornecida pelos fons e moléculas não ionizadas do meio, sendo expressa como miliosmoles por volume de solvente. Uma condição essencial para ótima nutrição e metabolismo das células em cultura é um adequado balanceamento ionnico, já que - transporte de íns e as mudanças nas concentraçöes iánicas dentro e fora das células afetam o transporte de outros nutri entes, como aminoäcidos e açücares, que direta ou indiretamen te irão afetar os sistemas básicos de síntese celular. Desde que a maior parte da atividade osmótica no melo de cultura pis ra células é fornecida pelos íns, seu controle é importante para regular o metabolismo celular, além de manter a tonicida de. As medidas de osmolaridade são úteis para conferir erros no preparo de meios, já que uma determinada formulação deve ser reproduzida lote a lote. A osmolaridade pode ser calculada através de tabelas de coeficientes osmóticos, mas para os fins do controle de qualidade é preferível medi-la diretamente atra 
vés de um osmòmetro (WAYMOUTH, 1973).

Entre as entidades biológicas que podem contaminar as culturas de células estäo bactérias com particular micoplasmas], fungos e vírus. Tudo que entra em contato com as células, tanto quanto os próprios estoques de células, po dem servir de fontes de contaminação.Para controlar a contaminação é importante estar seguro da ausência de organismos indesejáveis nos estoques e dispor de procedimentos capazes de determinar a presenga de micoplasma e virus, que são difíceis de controlar porque não podem ser removidos através das técnicas de filtração (RATAFIA, 1987a). A contaminação por micoplasma pode ser detectada por cultura direta, em caldo e ágar apropriados, ou por imunofluorescéncia (HAYFLICK, 1973 e MeGARRITY, 1979) enquanto que a presença de vírus é difícil de ser determinada, exigindo condiçóes muito elaboradas e es pecificas (LAMBERT a BIRCH, 1985 e SCHEIRER, 1987). En geraI as contaminações por fungos e bactérias são facilmente re conhecidas por uma inspeção grosseira, mas alguns contaminan tes somente produzem pequenas mudariças no meio e são compat veis com o crescimento das células na cultura.os procedimentos usados na verificação dessas contaminações devem ser ade quados para detectar todos os contaminantes conhecidos,poden do ser aplicados às culturas de células e as meios de cultu ra, soro, tripsina ou outros aditivas. Normalmente uma amostra de $10 \mathrm{ml}$ do meio a testar é suficiente para inocular, em duplicata, os diferentes meios : caldo tioglicolata, caldo soja 
tripticaseina, caldo Sabouraud dextrosado, ágar sangue e ágar desoxicolato, que devem ser incubados a $30^{\circ} \mathrm{C}$ e $37^{\circ} \mathrm{C}$ por 14 dias (CORIELL., 1973 ).

Ao se estudar crescimento, no sentido de proli feração celular, deve-se levar em conta a complexidade das in terações entre as células e seus ambientes físico, nutricional e hormonal. Em cultura, as células crescem segundo o clássico modelo de fases lag, crescimento exponencial, estacionária e decinio. A morte das células pode ser causada pela exaus tão de nutrientes e /ou fatores de crescimento, acúmulo de componentes tóxicos ou em resposta a sinais externos.para verificar as condições da cultura é fundamental acompanhar o estado da célula através do exame microscópico direto com co rantes apropriados, o que fornece informações a respeito da densidade da população celular, viabilidade, Indice mitótico. morfologia geral da célula e quantidade de detritos celulares presentes (ARATHOON E BIRCH, 1986 e PATTERSON, 1979).

A capacidade promotora de crescimento do meio de cultura ou algum dos seus componentes pode ser quantitativamente estimada através de diversos parámetros de crescimento que medem o nümero total de células (tempo de dobramento, densidade de saturação e eficiência de plaqueamentol ou a massa celular total (peso seco, determinação de proteínas)de forma direta ou indireta (GRIFFITHS, 1986b). 
Devido g grande variabilidade na sua qualidade - soro deve ser testado quanto á sua capacidade promotora de crescimento celular a de formagão de produto, sua pureza e. sua não-interferéncia nos processos de purificação, sempre em paralelo com um lote padrấo conhecido. Ao analisar a capacidade do soro em promover o crescimento das células, alguns pontos devem ser considerados : duração adequada do teste, incluin do mültiplas passagens; medida quantitativa do crescimento (velocidade de crescimento e rendimento celular) e uso de con dições (células, meio e substrato de crescimento) idênticas àquelas usadas na prática (LAMBERT e BIRCH, 1985; CARTWRIGHT, 1987 E RATAFIA, 1987 a). 
3. MATERIAL E MÉTDDOS

3.1. Célula utilizada

Neste trabalho utilizou-se a célula BHK-21(C13) originária de hamster (MACPHERSON e STOKER, 1982). Amostras desta Iinhagem celular. originalmente obtidas da Vallée Nordeste. são mantidas congeladas em reservatório de nitrogênio lfquido.

3.2. Meios de cultura e soluções

3.2.1. Meios minimos essenciais

Os seguintes meios foram utilizados: DME

(Dulbecco's modified Eagle's medium) e MEM (minimum essencial medium) adquiridos to laboratório Flow e o MGM (Eagle's medium Glasgow . modified) formulado e preparado no laboratörio. A composição des ses meios é apresentada na Tabela 1 . Todos os meios foram dis solvidos em água tratada por osmose reversa ou bi-destilada e 
esterilizados por filtração no sistema Mililpore, com membrana GS (diàmetro dos poros de $0.22 \mu$ ) distribuidos em porções de $200 \mathrm{ml}$ por frasco estéril e estocados em geladeira ( $4^{\circ} \mathrm{C}$ )por um período máximo de 60 dias.

Tabela 1 - Composição (mg/l) dos meios mínimos essenciais

\begin{tabular}{|c|c|c|c|}
\hline Componente & DME & MEM & MGM \\
\hline $\mathrm{CaCl}_{2}(\operatorname{anidro})$ & 200.00 & 200,00 & \\
\hline $\mathrm{CaCl}{ }_{2} \cdot 2 \mathrm{H}_{2} \mathrm{O}$ & & & 265,00 \\
\hline $\mathrm{Fe}\left(\mathrm{NO}_{3}\right)_{3} \cdot 9 \mathrm{H}_{2} \mathrm{O}$ & 0,10 & & 0.10 \\
\hline $\mathrm{KCI}$ & 400,00 & 400,00 & 400,00 \\
\hline $\operatorname{MgSO}_{4}(\operatorname{anidro})$ & 97.72 & 97,72 & \\
\hline $\mathrm{MgSO}_{4} \cdot 7 \mathrm{H}_{2} \mathrm{O}$ & & & 200,00 \\
\hline $\mathrm{NaCl}$ & 6400,00 & 6800,00 & 6400,00 \\
\hline $\mathrm{NaHCO}_{3}$ & 1200,00 & 1200,00 & 2750,00 \\
\hline $\mathrm{NaH}_{2} \mathrm{PO}_{4} \cdot \mathrm{H}_{2} \mathrm{O}$ & 124,00 & 140,00 & 124,00 \\
\hline Glicose & 4500,00 & 4500,00 & 4500,00 \\
\hline Piruvato de sōdio & 110,00 & & \\
\hline Vermelho de fenol & 15,00 & 10,00 & 15,00 \\
\hline Ampicilina & 25,00 & 25.00 & 25,00 \\
\hline Estreptomicina & 100,00 & 100,00 & 100,00 \\
\hline Fungison & 2,50 & 2,50 & 2.50 \\
\hline L-Arginina.HCI & 84.00 & 126,00 & 42.00 \\
\hline L-Cistina & & & 24,00 \\
\hline L-Cistina. $2 H C I$ & 62.57 & 31.29 & \\
\hline
\end{tabular}




\begin{tabular}{|c|c|c|c|}
\hline L-Fenilalanina & 66,00 & 32,00 & 33,00 \\
\hline Glicina & 30,00 & & \\
\hline L-Glutamina & 584,00 & 292,00 & 292,00 \\
\hline $\mathrm{L}$ - Histidina. $\mathrm{HCl} \cdot \mathrm{H}_{2} \mathrm{O}$ & 42,00 & 42,00 & 21.00 \\
\hline L-Isoleucina & 105,00 & 52,50 & 52,40 \\
\hline L-Leucina & 105,00 & 52.40 & 52.40 \\
\hline$L-L i \sin a \cdot H C I$ & 146.00 & 72.50 & 73.10 \\
\hline L-Metionina & 30,00 & 15,00 & 15,00 \\
\hline L-Serina & 42,00 & & \\
\hline L-Tirosina & & & 36.20 \\
\hline L-Tirosina(Sal dissōdico) & 104,20 & 52.10 & \\
\hline L-Treanina & 95,00 & 48.00 & 47,60 \\
\hline L-Triptofano & 16,00 & 10,00 & 8,00 \\
\hline L-Valina & 94,00 & 46,00 & 46.80 \\
\hline Acido fólico & 4,00 & 1,00 & 2,00 \\
\hline Cloreto de colina & 4,00 & 1.00 & 2,00 \\
\hline Inositol & 7,20 & 2,00 & 3,60 \\
\hline Nicotinamida & 4,00 & 1.00 & 2,00 \\
\hline Pantotenato de cálcio & 4,00 & 1,00 & 2.00 \\
\hline Piridoxal. HCI & 4,00 & 1,00 & 2,00 \\
\hline Riboflavina & 0.40 & 0.10 & 0.20 \\
\hline Tiamina.HCI & 4,00 & 1,00 & 2,00 \\
\hline
\end{tabular}

Fonte : Manual Gibco (1974) 


\begin{abstract}
Dois tipos de soros foram usados : soro fetal bovino (SFB) e soro bovino (SB). Estoques destes soros eram mantidos congelados $\left(-20^{\circ} \mathrm{C}\right)$ em alfquotas de $20 \mathrm{ml}$.
\end{abstract}

3.2.3. Caldo tripticaseina fosfata (CTF)

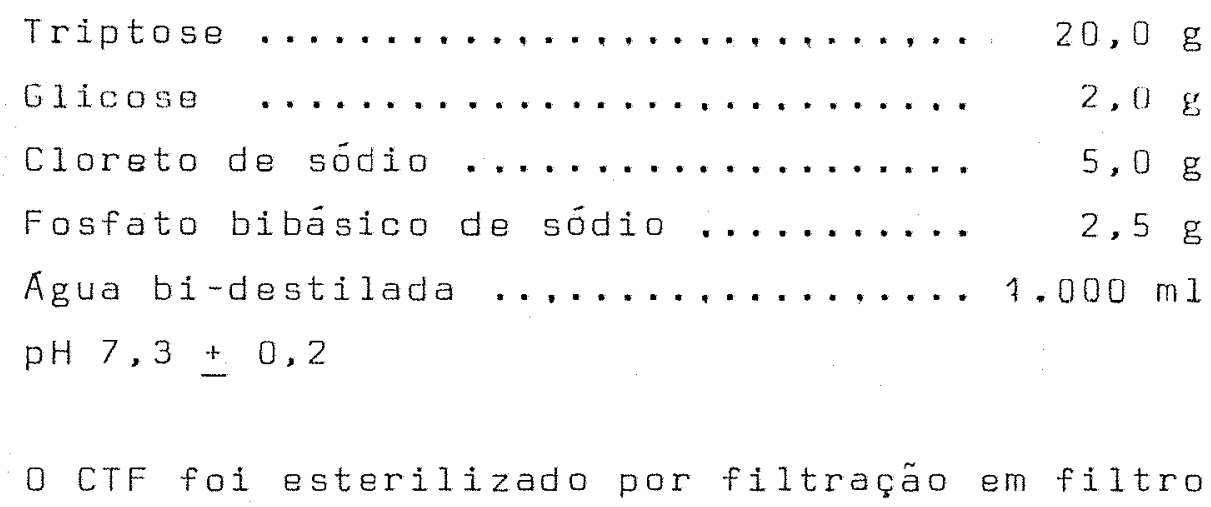

Milipore, com membrana GS $(0,22 \mu)$ distribuido em porções de $200 \mathrm{ml}$ por frasco estéril e mantido em geladeira $\left(4^{\circ} \mathrm{C}\right)$.

As amostras de CTF que foram utilizadas encontram-se relacionadas na Tabela 2.05 diferentes lotes de CTFBiobrás foram propositalmente formulados com matérias-primas de qualidade variável e testados na indústria. 
Tahela 2 - Relacão das amostras de caldo de tripticaseina fosfato(CTF)

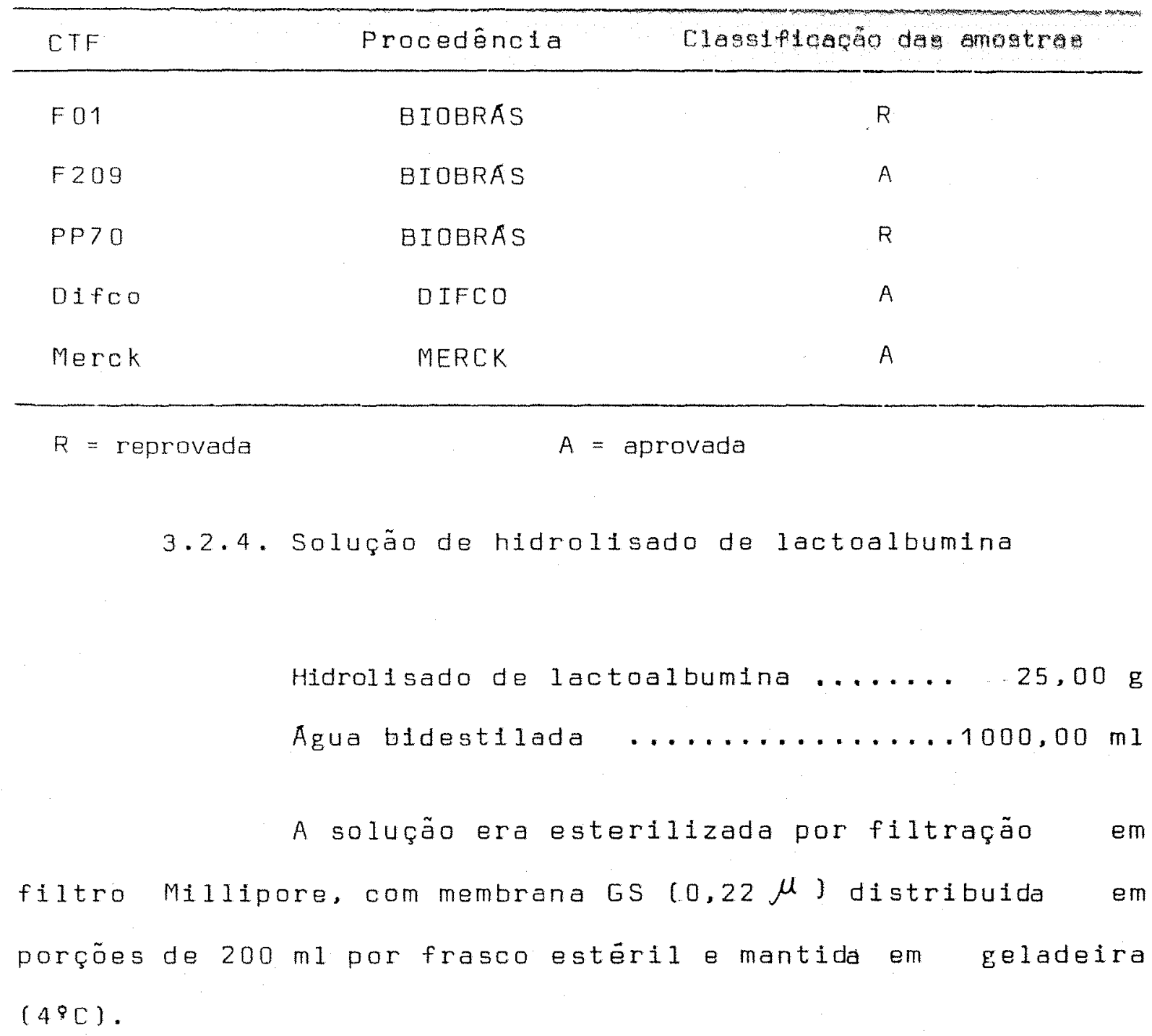


3.2.5. Solução de tripsina

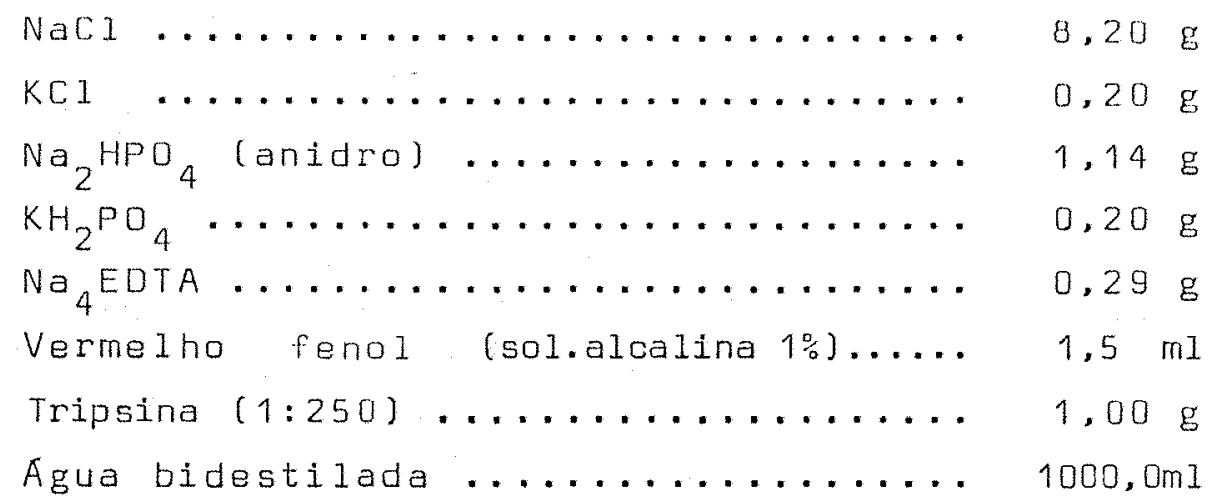

Após a dissolução dos ga1s, a solução permanecia em agitação, em baixa rotação, por 1 hora, sendo esterili zada por filtração em sistema Millipore (membrana GS $0,22 \mu$ ) e estocada congelada $\left(-20^{\circ} \mathrm{C}\right)$ em alíquotas de $20 \mathrm{ml}$.

3.2.6. Solução salina fosfato $\mathrm{pH} 7,2$ (PBS)

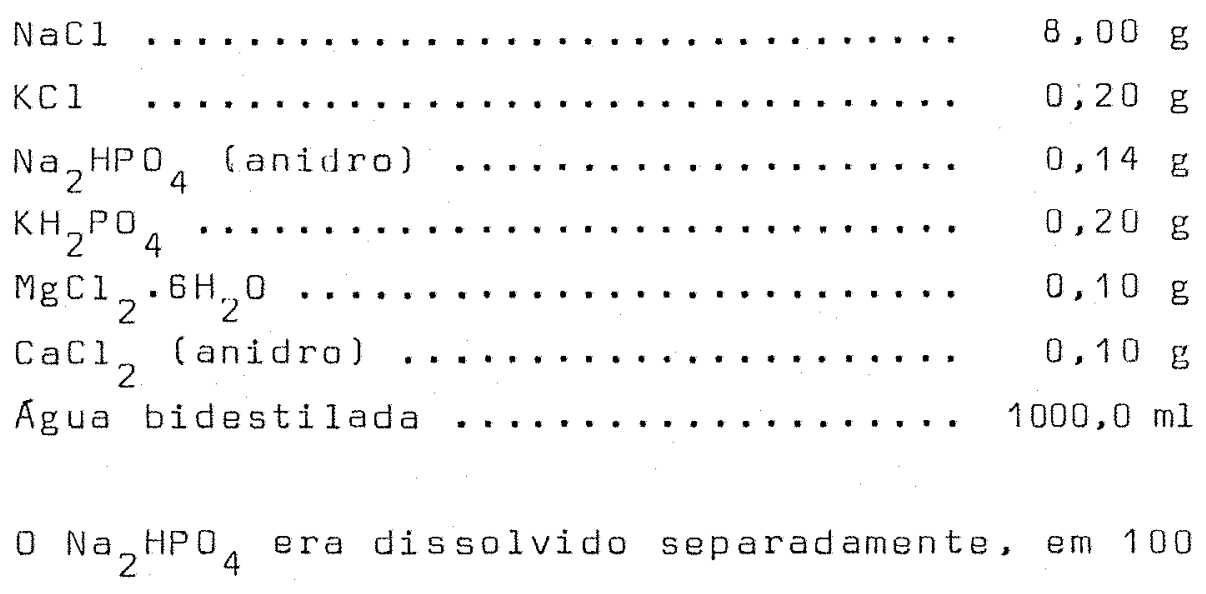

-200 ml de água bidestilada e os outros sais dissolvidos em conjunto no volume restante de água sendo acrescentados à solução de $\mathrm{Na}_{2} \mathrm{HPO}_{4}$. Após agitação, a solução era esterilizada por 
filtração em sistema Millipore (membrana GS $0.22 \mu$ ) e distribuida em porções de $200 \mathrm{ml}$ por frasco estëril e estocada em geladeira $\left(4^{\circ} \mathrm{C}\right)$.

3.2.7. Solução salina fosfato sem Ca $\mathrm{Cg}^{2+}$ ph 7.2 lPasar

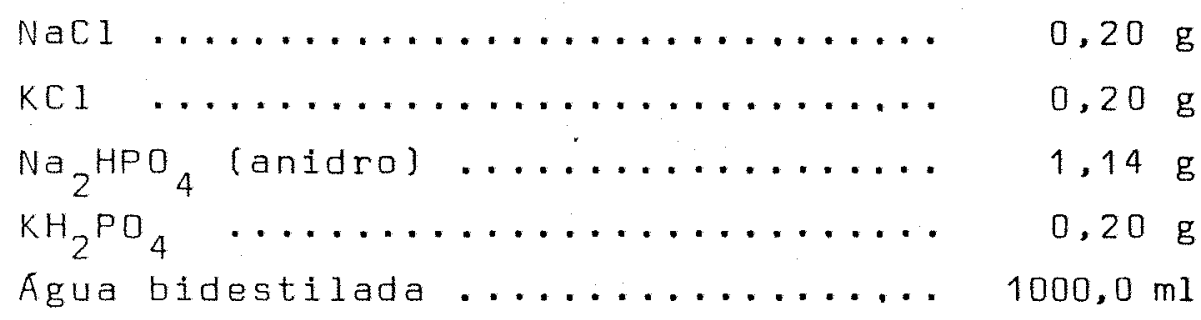

A solução era preparada segundo o fitem 3.2.6, sendo que todos os sais eram dissolvidos ao mesmo tempo.

3.2.8. Solução de azul de tripan

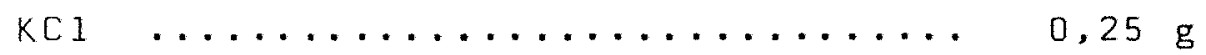

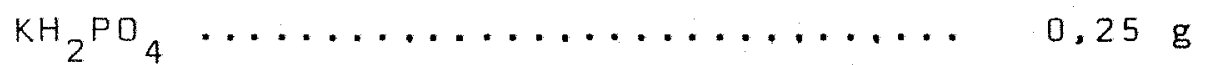

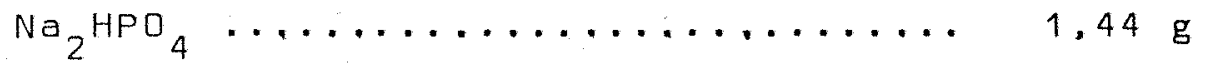

Azul de tripan .............. 5,00 g

Agua bidestilada ............... 1000,0 ml

A solução era esterilizada por filtração no sis tema Milipore (membrana GS $0.22 \mu$ )e estorada en geladeira a $4 \stackrel{\circ}{\mathrm{C} .}$ 
3.2.9. Solução de vermel ho fenol a $1 \%$

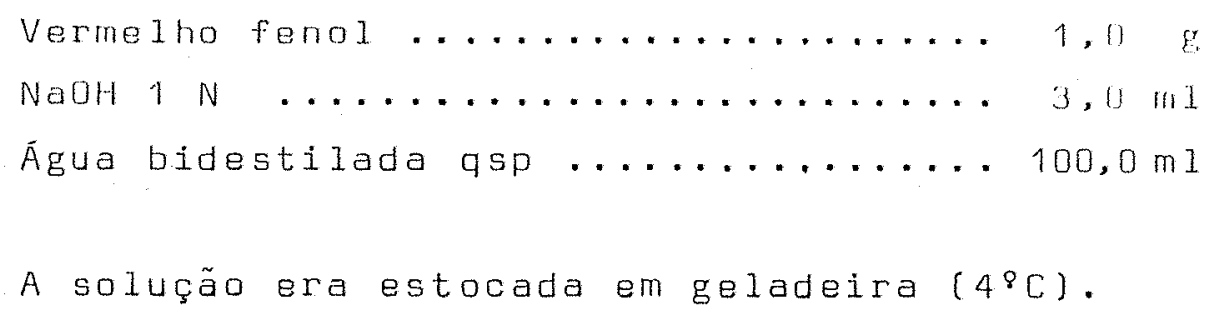

3.2.10. Solução de cristal violeta

Cristal violeta ............. 5,0 g

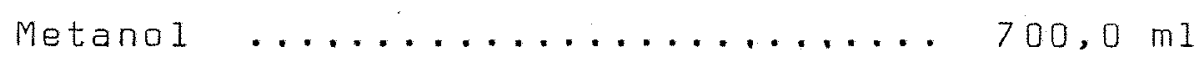
Agua bidestilada ............. 300,0 ml A solução era preparada dissolvendo-se o cristal violeta no metanol, acrescentando-se a água bidestilada e deixando em agitação durante 1-2 horas, sendo estocada em temperatura ambiente.

3.3. Preparação de suspensão homogênea de células

Culturas de células BHK-21 crescendo em substrato sólido (monocamadas) eram tripsinizadas para remover as oẹ lulas da superficie.para tanto, o meio de cultura era aspirado com pipeta Pasteur (Iigada a bomba de vácuo) e a camada de células lavada com PBSA, tomando-se o cuidado de não despre- 
gar as células mitaticas.para garrafas de $25 \mathrm{~cm}^{2}$ a tripsinização era feita com $0,5 \mathrm{ml}$ de solução de tripsina.Quando as células começavam a despregar, era adicionado $1.0 \mathrm{ml}$ de PBSA. As células eram separadas pipetando-se com pipeta Pasteur de ponta fina, para cima e para baixo e, rapidamente, adicionava - se $0.5 \mathrm{ml}$ de melo contendo soro (DME + 10\% SFB) pipetando-se para cima e para baixo para formar uma suspensão homogênea de células \{sem grumos\}. Quando necessärio, a suspansão ara dllu1 da, acrescentando-se mais PBSA.

3.4. Manutenção e congelamento de estoques 3.4.1. Preparo de estaques celulares

Novas culturas eram preparadas adicionando-se uma amostra da suspensão de células a uma garrafa de $25 \mathrm{~cm}^{2}$ contendo $4 \mathrm{mI}$ de meio fresco (OME + 10\% SFB) pipetando-se para cima e para baixo, para homogeneizar a suspensão. Após injeção da mistura de $5 \% \mathrm{CO}_{2}+95 \%$ ar comprimido, as garrafas eram ve dadas e incubadas a $37^{\circ} \mathrm{C}$ durante $9-12$ dias, 0 meio era trocado a cada 3 dias.

3.4.2. Congelamento de células 
centrifugada a $2000 \mathrm{~g}$ por aproximadamente 3 minutos

para eliminar tripsina.Após remoção do sobrenadante, as células eram ressuspensas em meio OME contendo 10\% DMSO (dimetil sulfóxido) previamente esterilizado em filtro seitz e $10 \%$ SFB para uma concentração de 1 a $210^{6}$ células/ml. Após distribuição de $1 \mathrm{ml}$ desta supensão por ampola, as amostras eram incubadas por 30 minutos a $4^{\circ} \mathrm{C}$ e depois transferidas para tanque de nitrogènio Iŕquido.

\subsubsection{Descongelamento de células}

Uma ampola era retirada do nitragênio líquido e colocada em banho maria a $37^{\circ} \mathrm{C}$. Logo após o descongelamento, o canteüdo da ampola era transferido para garrafas de $25 \mathrm{~cm}^{2}$ contendo $4 \mathrm{ml}$ de DME $+10 \% \mathrm{SFB}$ (previamente injetadas com a mistura de $5 \% \mathrm{CO}_{2}$ e $95 \%$ ar comprimido e incubadas a $37^{\circ} \mathrm{C}$ ) e incubadas a $37^{\circ} \mathrm{C}$ durante $3-5$ horas até as céIulas aderirem à garrafa.o meio era então trocado para eliminar o. DMSO e as garrafas novamente incubadas a $37{ }^{\circ} \mathrm{C}$, após injeção da mistura de $\mathrm{CO}_{2}$ + ar comprimida. 
3.5. Crescimento celular em monocamada

3.5.1. Determinação de $T_{D} e D_{S}$ através de curvas de crescimento

A partir de uma suspensão homogênea de células feita em meio MEM + 5\% SB, conforme descrito no item $3.3,5 \times 10^{4}$ células eram distribuidas por placa de petri de plástico. des cartävel. de $3.5 \mathrm{~cm}$ de diâmetro, num volume de $2 \mathrm{ml}$ por placa. As placas eram incubadas a $37^{\circ} \mathrm{C}$, em camara úmida lcalxas de plàstico contendo, no fundo, uma camada de ospuma ambebida em água, devidamente seladas com vaselina) após injeção da mistú ra de $5 \% \mathrm{CO}_{2}$ e $95 \%$ ar comprimido. Após 24 horas de incubação 2 placas eram coletadas pora contagem de células, conforme descrito no item 3.5.2.0 restante das placas tinha o meio removi do, a camada de células lavada com PBS e os diferentes meios a serem testados eram adicionados, sendo $82 \%$ meio mínimo essen cial (DME, MEM ou MGM) + $8 \%$ soro (SB ou SFB) + 10\% CTF. Estas placas eram reincubadas e, durante um periodo de 8 dias, a ca da 24 horas, 1-2 placas eram coletadas para observação ao microscópio e contagem das cëlulas.o meio era trocado a cada 3 dís. Após determinação do nümero de cẽlulas/placa para cada ponto, traçava-se o gráfico do nümero de cẻlulas/placa em fun ção do tempo (horas) para determinar $T_{D}$ ftempo de dobramento da população, unidade ém horas) e $D_{S}$ (densidade máxima ou de saturação que a célula atinge, representada por nümero de células $/ \mathrm{cm}^{2}$ ). os desvios entre as duplicatas estão indicados 
nos grä́licos a não ultrapassaram $10 \%$.

$$
\begin{aligned}
& \text { 3.5.2. Loleta de cëlulas para contagem da curva de } \\
& \text { crescimento }
\end{aligned}
$$

- meio das placas era removido e a camada de cểlulas lavada rapidamente com 2,0 ml de PBSA e tripsinizada

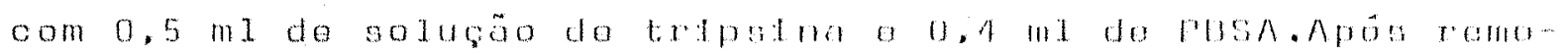
ção das células da superfície e dissociação das mesmas com au xílio da pipeta Pasteur, a suspensão homogênea de células $(0,9 \mathrm{ml})$ era transferida para um tubo de ensaio, fixada com $0,1 \mathrm{ml}$ de formaldeido $40 \%$ e contada em cámara de Neubauer.

3.5.3. Determinação da eficiência deplaqueamento (E.P.)

Uma diluição seriada era feita a partir de uma suspensão homogênea de cếlulas em meio MeM + $5 \% \mathrm{SB}$, como descrito no item 3.3. Conforme descrito no item $3.5 .1,1 \times 10^{3}$ cé Iulas eram distribuidas por placa de Petri.Após 24 horas de incubação o meio de todas as placas era removido e a camada de células lavada com pBS antes de adicionar os diferentes meios a serem testados $182 \%$ meio mínimo essencial + 8\% soro + $10 \%$ CTF). As placas eram novamente incubadas e o meio renovado periodicamente a cada 3 dias até o aparecimento de colónias macroscópicas 
( 7 dias). Após este periodo, o melo das placas era removido e as células fixadas com 10\% formaldeido em pas por 5-10 minu tos.Depois da remoção do formaldeido, as células eram coradas utilizando cristal violeta $0,5 \%$. Colónias com mais de 50 células eram contadas (a olho nú) e a eficiência de plaquea mento (EP) determinada segundo a förmula :

$$
E P(\%)=\frac{\text { nûmero de colônias }}{\text { nümero de células plaqueadas }} \times 100
$$

Todas as determinações foram feitas em duplicata, sendo os desvios menores do que $10 \%$ :

3.6. Crescimento celular em suspensão

$$
\text { 3.6.1. Crescimento em frasco "spinner" }
$$

Uma suspensao homogênea de células era preparada de acordo com o Item 3,3 de Material e Métodos.7,5 $\times 10^{6}$ células, em pequeno volume $(1$ a $2 . \mathrm{ml})$ de meio MGM + $8 \% \mathrm{SB}$, eram inoculadas em um frasco tipo "spinner" contendo $15 \mathrm{ml}$ do meio a ser testado (MGM + $8 \%$ SB + $10 \%$ CTF) de modo a obter, inicialmente, $5 \times 10^{5}$ células/ml.0s frascos "spinner" eram então injetados com $5 \% \mathrm{Ca}_{2}+95 \%$ ar comprimido e incubados em estufa a $37^{\circ} \mathrm{C}$, com agitação constante de aproximadamente $250 \mathrm{rpm}$ (sobre um agitador magnético rotativo), A oada 24 horas, durante 10 dias, coletavam-se amostras $(1 \mathrm{~m} 1)$ da cultura, 
.38 .

as quals eram diluidas com $1 \mathrm{ml}$ de solução de azul de tripan

e contadas em câmara de Neubauer para determinar o número de células viáveis /ml Cas células viăveis excluem o corante e permanecem trasnparentes, ao contrârlo das células mortas que tornam-se azuisl. A cultura era entao diluida para a densidade inicial $\left(5 \times 10^{5}\right.$ cêlulas/ml) atravës da retirada de volume adequado de suspensão e adição de ligual volume de meto fresco, e novamente incubada.

3.6.2. Crescimento em escala industrial

Conforme descrito em 3.6.1., mas utilizando-se frascos com capacidade para $1000 \mathrm{ml}$ e contendo $400 \mathrm{ml}$ de meio sobre uma mesa com agitação magnética rotativa de $250 \mathrm{rpm}$, dentro de uma sala-estufa a $37^{\circ} \mathrm{C}$. Nesse sistema o ajuste do $\mathrm{pH}$ era feito, se necessärio, pela injeção de $\mathrm{CO}_{2}$ (para abaixar o $\mathrm{pH}$ ou de ar comprimido. 
4.1. Anälise do crescimento de células BHK-21 em monocamada

Diversos tipos de melos de cultura têm sldo utilizados para a cultura de células "in vitro"(HAM a McKEEHAN, 1979). Independente do tipo de melo, entretanto, a suplementação com soro (geralmente bovino) é considerada essencial.Para determinadas aplicações tém sido ut1lizados outros auplementoo além do soro, como os complexos protelcos indefinidos de peptonas, hidrolisado de lactoalbumina ou caldo tripticaseina fosfato (SPIER, 1980 e TELLING e RADLET, 1971).0s ensaios de eficienncia de plaqueamento e determinação de TD e DS através de curvas de crescimento são procedimentos de pequena escala que podem ser usados para estimar quantitativamente a capacidade promotora de crescimento de meios de cultura ou algum dos seus componentes (GRIFFITHS, 1986b).Para determinar as con dições ideais para testar meios de cultura e suplementos usados 
na produção industrial de vacinas, cêlulas BHK-21 raram submę tidas a crescimento em diversos meios de cultura suplementados com diferentes tipos de soro e diferentes amostras de CTF. Inicialmente procurou-se verificar a eficácia do ensaio de eficiéncia de plaqueamento na avaliação do potencial mito gènico de alguns meios de cultura e suplementos.

4.1.1. Eficiència de plaqueamento

Para determinar as condições ideais de cultura. células BHK-21 foram submetidas a ensaios de eficiencia de plaqueamento em meios DME. MEM e MGM suplementados com caldo tripticaseina fosfato (CTF) elou soro bovino (SB) ou soro fetal bovino (SFBI. os resultados desses experimentos en contram-se nas tabelas 3 e 4 . 
Tabela 3 - Efeito do tipo de meio de cultura e soro na eficiéncia de plaquenmento (E.P) de células BHK-21 cultiva das em melo minimo + $8 \%$ soro + 10\% CTF.

\begin{tabular}{|c|c|c|c|}
\hline $\begin{array}{l}\text { Meio de } \\
\text { cultura }\end{array}$ & Soro & CTF & $\begin{array}{l}\text { E.P } \\
(\%)\end{array}$ \\
\hline \multirow{5}{*}{ DME } & & Difco & 22,6 \\
\hline & SB & - & 1,3 \\
\hline & & & 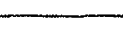 \\
\hline & & Difco & 36.6 \\
\hline & SFB & - & 3,8 \\
\hline \multirow{5}{*}{ MEM } & & Difco & 6,8 \\
\hline & SB & - & 0.4 \\
\hline & & & \\
\hline & & Difco & 32,2 \\
\hline & SFB & - & 3,0 \\
\hline \multirow{5}{*}{ MGM } & & Difco & 1.4 \\
\hline & SB & - & 0,2 \\
\hline & & & \\
\hline & & Difco & 15,3 \\
\hline & SFB & - & 1,7 \\
\hline
\end{tabular}


Os dados da Tabela 3 mostram como o meio de cultura e o soro afetam o crescimento de células BHK-21.A ati vidade promotora de crescimento do SFB é muito superior à do SB, sendo este efeito mais acentuado no meio MGM.o meio DME proporciona melhores condições para o crescimento e desenvol vimento de colónias do que o MEM, enquanto que o crescimento no meio MGM é bem inferior aos outros.quando se compara ome e MEM suplementados com SFB, nentuma diferença significativa é encontrada, mas quando a suplementação é feita com SB.exis te uma grande diferença, ou seja, a capacidade promotora de crescimento do MEM + SB é muito mais baixa.A suplementação com CTF é essencial uma vez que na ausencia de CTF observa- se drästica redução na eficiência de plaqueamento lde mais de $90 \%$, independente do meio de cultura utilizadol. Como pode ser visto, os meios MGM e MEM suplementados apenas com SB conduzem a uma eficiência de plaqueamento baixísima, menor que $1 \%$ 
Tabela 4 - Efeito de diferentes tipos de CTF na eficiéncia de plaqueamento (E.P) de células BHK-21 cultivadas em meio minimo $+8 \% 50$ ro $+10 \%$ CTF.

\begin{tabular}{|c|c|c|c|}
\hline $\begin{array}{l}\text { Meio de } \\
\text { cultura }\end{array}$ & Soro & CTF & $\begin{array}{l}\text { E.P } \\
(\%)\end{array}$ \\
\hline \multirow{6}{*}{ DME } & & F209 & 6.9 \\
\hline & SB & $01 f c 0$ & 22,6 \\
\hline & & - & 1,3 \\
\hline & & $F 209$ & 6.7 \\
\hline & SFB & Difco & 36.6 \\
\hline & & - & 3,8 \\
\hline \multirow{6}{*}{ MEM } & & F 209 & 3,6 \\
\hline & SB & Difco & 6,8 \\
\hline & & - & 0,4 \\
\hline & & $F 209$ & 3,8 \\
\hline & SFB & Difco & 32,2 \\
\hline & & - & 3,0 \\
\hline \multirow{6}{*}{ MGM } & & F 209 & 2,6 \\
\hline & $\mathrm{SB}$ & Difco & 1,4 \\
\hline & & - & 0,2 \\
\hline & & $F 209$ & 2,6 \\
\hline & SFB & Difco & 15,3 \\
\hline & & - & 1.7 \\
\hline
\end{tabular}


Ao analisar diferentes amostras de CTF (F209 e Difcoj cujos resultados estão na Tabela 4 nota-se uma diferen ca nas respostas aos diferentes CTFs.Tanto CTF-Difco quanto F209 proporcionam melhor crescimento para células BHK no uME, seguido do MEM e MGM.Entretanto, ao usar CTF-F209, os soros bovino e fetal bovino apresentam o mesmo efeito na proliferação das células, ao contrário do CTF-Difco.Em todas as condi Ções os resultados de eficiéncia de plaqueamento para CTFDifco foram bem superiores.

De um ensaio para outro foi notada uma enorme variabilidade nos resultados de eficiéncia de plaqueamen to para o mesmo CTF. A Tabela 5 apresenta os resultados abtidos em diferentes ensaios, quando cëlulas BHK-21 foram cultivadas em meio suplementado com diferentes amostras de CTF, sendo uma delas de qualidade comprovada (CTF-Difoo) e outra reprovada $(C T F-F 01)$ 
.45 .

Tabela 5 - Resultados de eficiéncia de plaqueamento (E.P)para células BHK-21 em diferentes ensaios. Células cultivadas em me10 MEM + $8 \% 5 B+10 \%$ CTF (Difco ou F01).

\begin{tabular}{|c|c|c|c|}
\hline \multirow{2}{*}{ Ensaio } & \multicolumn{3}{|c|}{$E \cdot P \cdot(\%)$} \\
\hline & CTF - DIfCo & CTF-FO1 & Difco/F01 \\
\hline$A$ & 4,9 & 0.4 & 12,3 \\
\hline 日 & 36,7 & 5,2 & 7,1 \\
\hline C & 9,8 & 3,0 & 3,3 \\
\hline$D$ & 42,8 & 0,9 & 47,6 \\
\hline$E$ & 3,7 & 1,4 & 2,6 \\
\hline F & 25,8 & 8,6 & 3,0 \\
\hline G & 11,7 & 0,2 & 58,5 \\
\hline$H$ & 7.5 & 0.0 & - \\
\hline $\bar{x}$ & 17.86 & 2,46 & \\
\hline 5 & 15,21 & 3.03 & \\
\hline
\end{tabular}

Nota-se que o CTF-Difco esteve sempre melhor que CTF-F01, sendo que este ültimo chegou a apresentar resul tados nulos ou quase nulos.Pode-se verificar parém que as va lores de eficiéncia de plaqueamento para um mesmo CTF são muito variáveis de um ensaio para outro.Além disso, a razão entre CTF-Difco e CTF-F01 também foi muito variăvel. 
A derisidade celular inicial no plaqueamento e o estado fisiológico da cultura original a partir da qual ë preparada a suspensão de plaqueamento são as principais responsäveis por essa variabilidade. E muito importante que a cultura original esteja em condições ótimas : fase exponencial, meio não exaurido e pH não muito ácido nem muito alcaIino, para garantir melhor viabilidade das células. A suspensão de células deve ser homogẽnea, com um nủmero reduzido de células para permitir que cada célula fique totalmente isolada da outra impedindo a ocorrência de "cross-feeding" (uma célula complementando as caréncias das outras e "condiciona mento do meio" Cacúmulo de substàncias secretadas pelas célu Ias propiciando o crescimento das mesmas) (ARMELIN, 1986).

Apesar da medida da eficiência de plaqueamento ser o melhor e mais rigoroso indicador de viabilidade celular, a grande variabilidade de resultados inviabilizou a sua utilização na avaliação da atividade estimulatória do crescimento celular de CTF ou outros suplementos.Daí passar- se a utilizar curvas de crescimento para avaliar a atividade mitogènica dos diversos componentes do meio na promoção do crescimento de cólulas BHK-21.

4.1.2. Curvas de crescimento

Cểlulas BHK-21 foram submetidas a ensaios de 
determinação de $T_{D}$ e $D_{S}$ através de curvas de crescimento pa ra verificar a importância do meio basal, do soro e de suple mentos na sua proliferação.

As Figuras 1 e 2 e a Tabela 6 mostram a ativi dade estimulatöria de CTF sobre o crescimento de células BHK-21 em diferentes meios : DME, MEM e MGM.

Na Figura 1 pode-se verificar que o meio MEM suplementado apenas com soro bovino não permite o crescimento de células BHK-21, sendo necessário suplementá-lo com CTF. A adição de CTF leva a uma redução do To para aproximadamen te a metade (de 65 para 36 horas) e a um aumento dramático na $D_{S}$, conforme mostram os dados da Tabela 6. Ao conträrio,o meio DME suplementado somente com SB favorece um crescimento razoável das células, sendo melhorado pela suplementação com CTF.Não ocorre muita diferença nos valores de To e OS (Tabela 6). Esses resultados indicam que : a) o meio DME é melhor do que MEM; b) o CTF é um suplemento importante para a proli feração de células BHK sendo absolutamente essencial quando as células são mantidas em MEM + SB. 


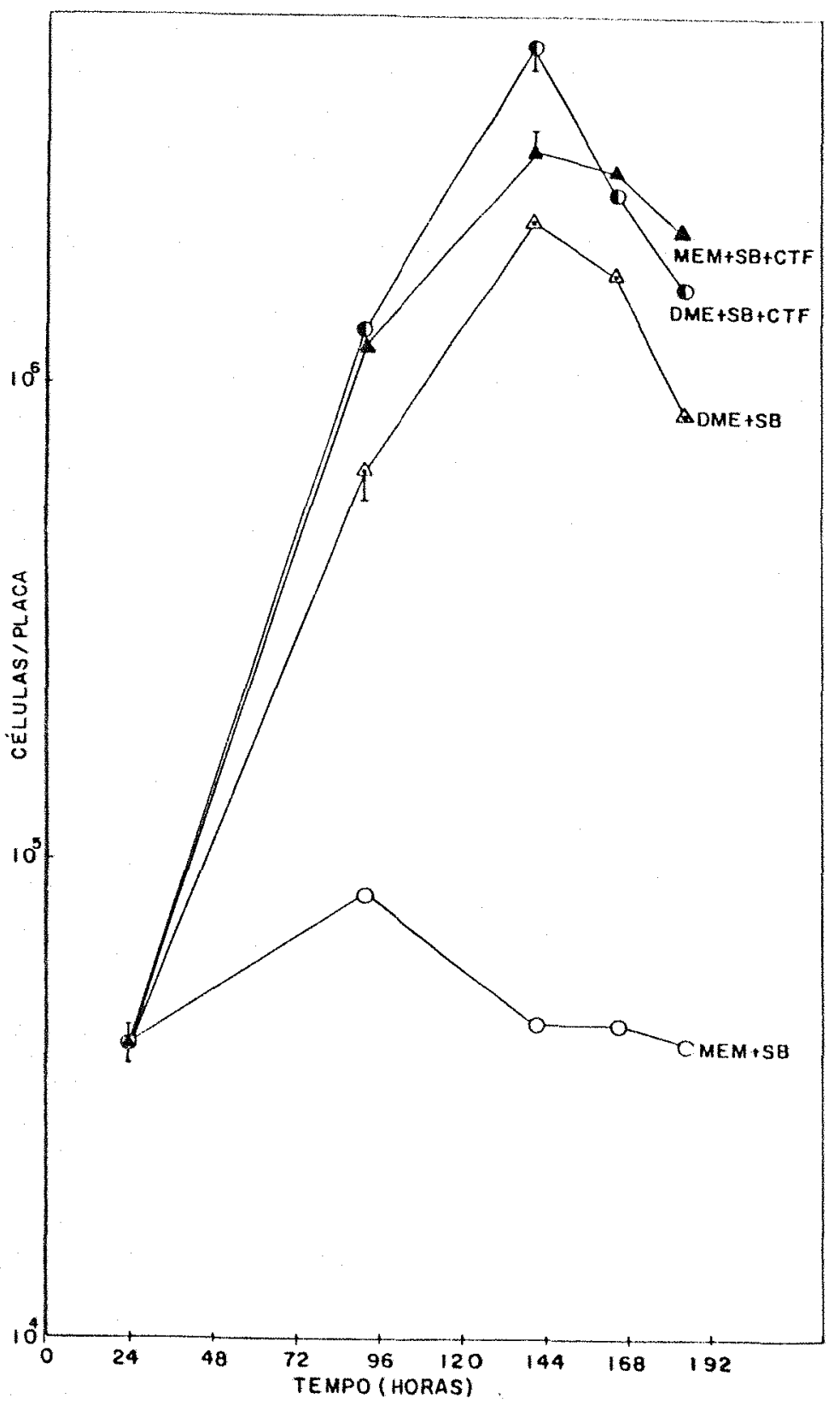

Figura 1 - Atividade estimulatöria de CTF sobre crescimento de cêlulas BHK-21 em meios DME e MEM suplementados com SB.O-OMEM + $8 \%$ SB; $\triangle M E M+8 \% 5 B+10 \%$ CTF-DifCO; $\triangle \triangle D M E+8 \% \mathrm{SB} ; \triangle D M E+8 \% \mathrm{SB}+10 \% \mathrm{CTF}-$ Difco. 
Tabela 6 - Valores de $T_{D}$ e $D_{S}$ para cếlulas BHK-21 crescendo em meio mintmo $+8 \% \mathrm{SB}+10 \%$ CTF.

\begin{tabular}{|c|c|c|c|}
\hline $\begin{array}{l}\text { Meio de } \\
\text { cultura }\end{array}$ & CTF & $\begin{array}{c}T_{D} \\
(\text { horas })\end{array}$ & $(c) e$ lus las $\left./ \mathrm{cm}^{2} \times 10^{5}\right)$ \\
\hline \multirow{3}{*}{ DME } & - & 30 & 2,2 \\
\hline & Difco & 24 & 5,2 \\
\hline & - & 66 & 0,09 \\
\hline \multirow[t]{2}{*}{ MEM } & $D i f c o$ & 36 & 3,1 \\
\hline & - & $\infty$ & 0,05 \\
\hline M GM & $01 \mathrm{fco}$ & 15 & 2.2 \\
\hline
\end{tabular}


.50 .

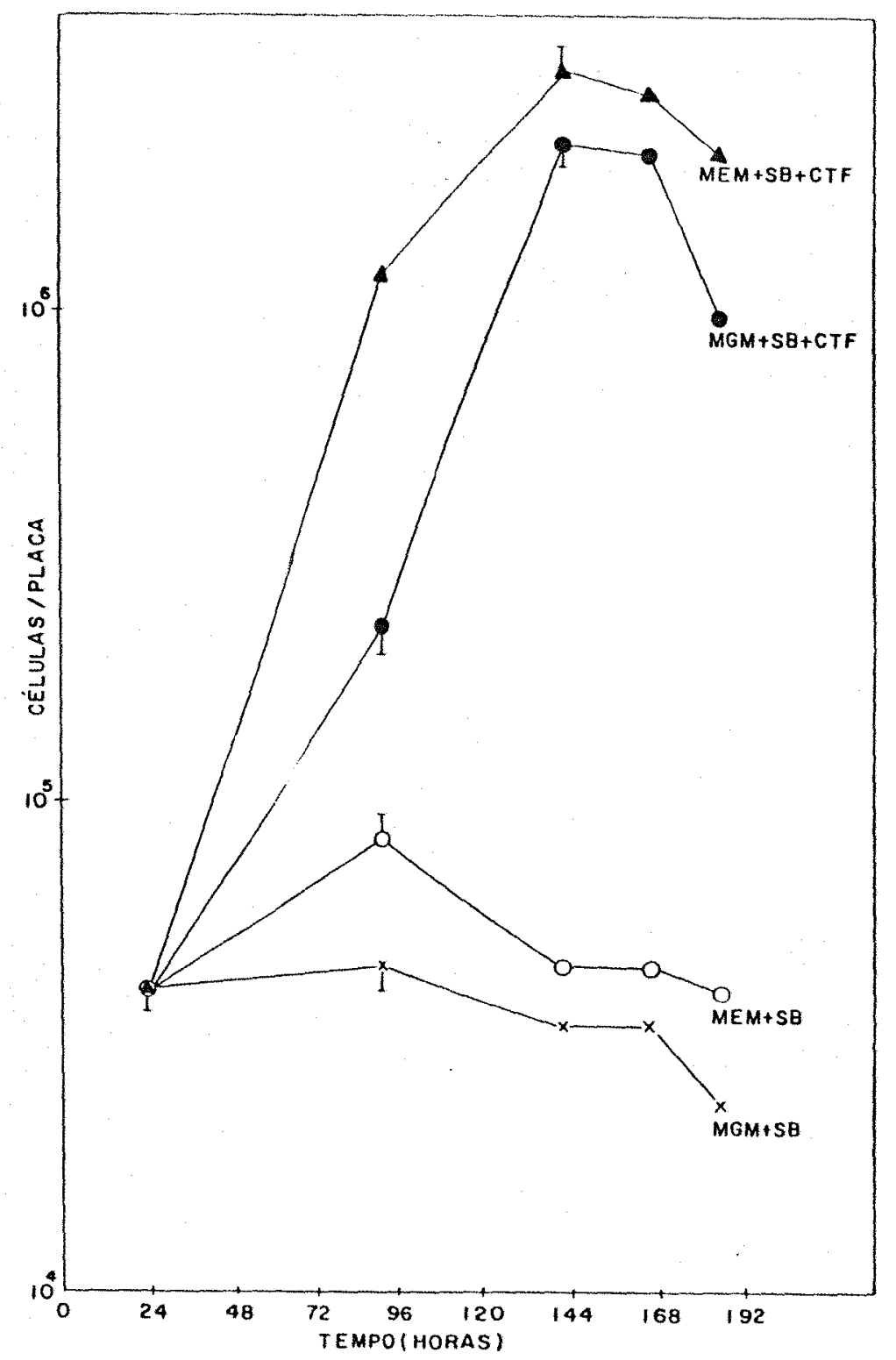

Figura 2 - Atividade estimulatória de CTF sobre o crescimento de cểlulas BHK-21 em meios MEM e MGM suplementados com SB. $\longleftarrow \times M G M+8 \% \mathrm{SB} ;-\mathrm{MGM}+8 \% \mathrm{SB}+10 \% \mathrm{CTF}-$ $-\mathrm{Difco}: \mathrm{O}-\mathrm{MEM}+8 \% \mathrm{SB} \triangle \triangle \mathrm{MEM}+8 \% \mathrm{SB}$ $+10 \%$ CTF DIfCo. 
Pelos resultados da Figura 2 e da Tabela 6 no ta-se que os meios MEM e MGM são semelhantes, só promovendo - crescimento quando suplementados com soro e CTF.Na auséncia de CTF as densidades máximas de crescimento atingidas fo ram muito baixas, Inferiores a $0.1 \times 10^{5}$ células/cm ${ }^{2}$ e os va lores de To muito elevados (Gg horas para MEM) ou até nulos lem MGM não houve dobramento da população dentro de um perío do de 190 horasl. A adição de CTF proporctona uma redução do $T_{D}(36$ e 15 horas para MEM e MGM, respectivamente) e uma elevaçäo na $D_{S}$ para $3,1 \mathrm{e} 2,2 \times 10^{5}$ células/ $\mathrm{cm}^{2}$. respectivamen te.

As Figuras 3,4 e 5 e a Tabela 7 mostram o efeito dos soros bovino e fetal bovino e suas interações com os meios de cultura na promoção do crescimento de oélulas BHK -21 . 


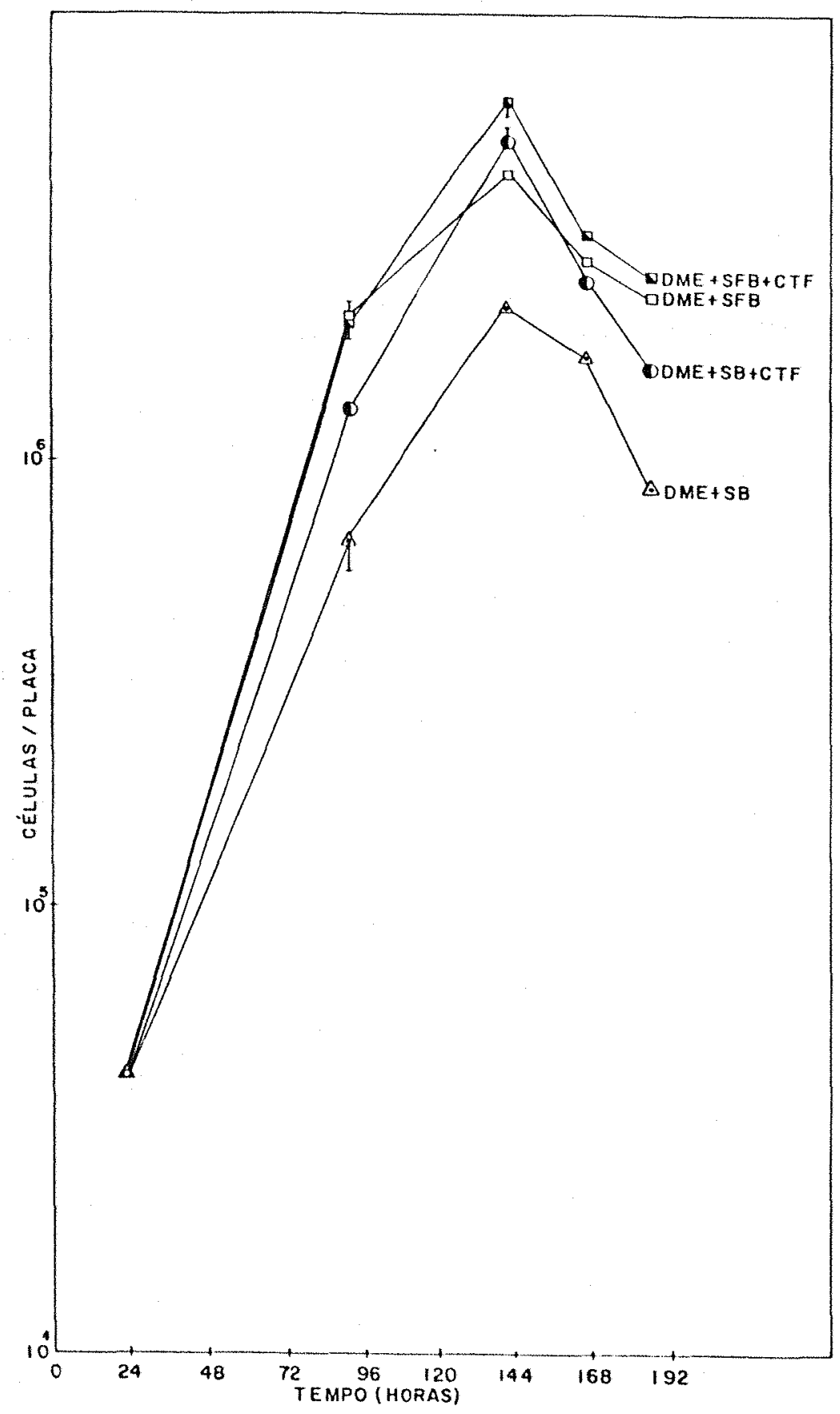

Figura 3 - Efeito de soros bovino e fetal bovino sobre o cres cimento de células BHK-21 mantidas em meio DME suplementado com CTF-Difco. $\square \square D M E+8 \%$ SFB; $\triangle D M E+8 \% \mathrm{SFB}+10 \%$ CTF-DifCo; $\triangle \mathrm{DME}+8 \%$ $\mathrm{SB}: \mathrm{DME}+8 \% \mathrm{SB}+10 \% \mathrm{CTF}-\mathrm{DifCO}$. 
.53.

Para a proliferação de células BHK-21, o SFB é superior em relação ao SB e a combinação DME + SFB praticamente dispensa a adição de CTF, de acordo com a Figura 3.A resposta à adição de CTF é mals acentuada quando se usa SB, com au mentro da $D_{S}$ de $2,2 \times 10^{5}$ no DME + SB para $5.2 \times 10^{5}$ células/ $\mathrm{cm}^{2}$ no DME + SB+CTF (Tabela 7).

Tabela 7 - Valores de $T_{D}$ e $D_{S}$ para células BHK-21 crescendo em meio mínino + $8 \%$ soro + 10\% CTF-Difco.

\begin{tabular}{|c|c|c|c|c|}
\hline $\begin{array}{l}\text { Meio de } \\
\text { cultura }\end{array}$ & Soro & CTF & $\begin{array}{c}\text { TD } \\
(\text { horas })\end{array}$ & $\frac{\mathrm{D}_{\mathrm{S}}}{\left.\text { (células } / \mathrm{cm}^{2} \times 10^{5}\right)}$ \\
\hline \multirow{4}{*}{ DME } & SB & - & 30 & 2,2 \\
\hline & & Difco & 24 & 5,2 \\
\hline & SFA & - & 46 & 4.4 \\
\hline & & Difco & 30 & 6,4 \\
\hline \multirow{4}{*}{ MEM } & SB & - & 66 & 0,09 \\
\hline & & Difco & 36 & 3,1 \\
\hline & $\mathrm{SFB}$ & - & 28 & 1,0 \\
\hline & & Difco & 26 & 5,1 \\
\hline \multirow{5}{*}{ MGM } & $\mathrm{SB}$ & - & $\infty$ & 0.05 \\
\hline & & DIfco & 15 & 2.2 \\
\hline & & & & \\
\hline & SFB & - & 36 & 1,0 \\
\hline & & Difco & 40 & 4,6 \\
\hline
\end{tabular}


Os dados da Tabela 7 mostram que ocorre uma redução no To com a adição de CTF. Entretanto, era de se espe rar que a associação DME e SFB resultasse em valores de To menores do que a combinacão DME + S日, o que não aconteceu.

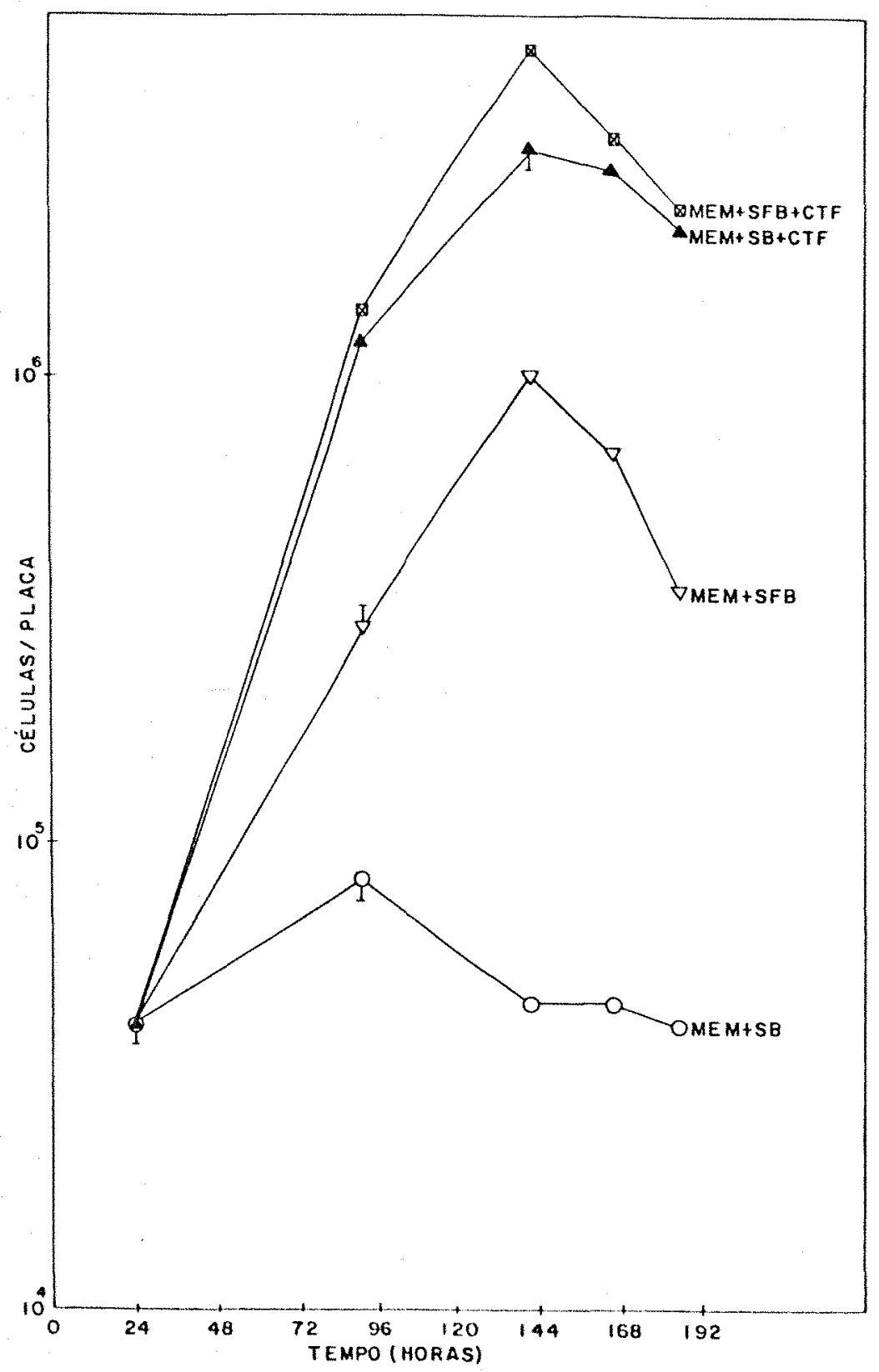

Figura 4 - Efeito de soros bovino e fetal bovino sobre o crescimento de células BHK-21 mantidas em meio MEM suplementado com CTF-Difco. $\nabla \nabla M E M+8 \%$ SFB; $\square-\triangle M E M+8 \%$ SFB + 10\% CTF-DifCo; O-O MEM $+8 \%$ SB; A MEM + $A \% S B+10 \%$ CTF-DifCo. 
.55.

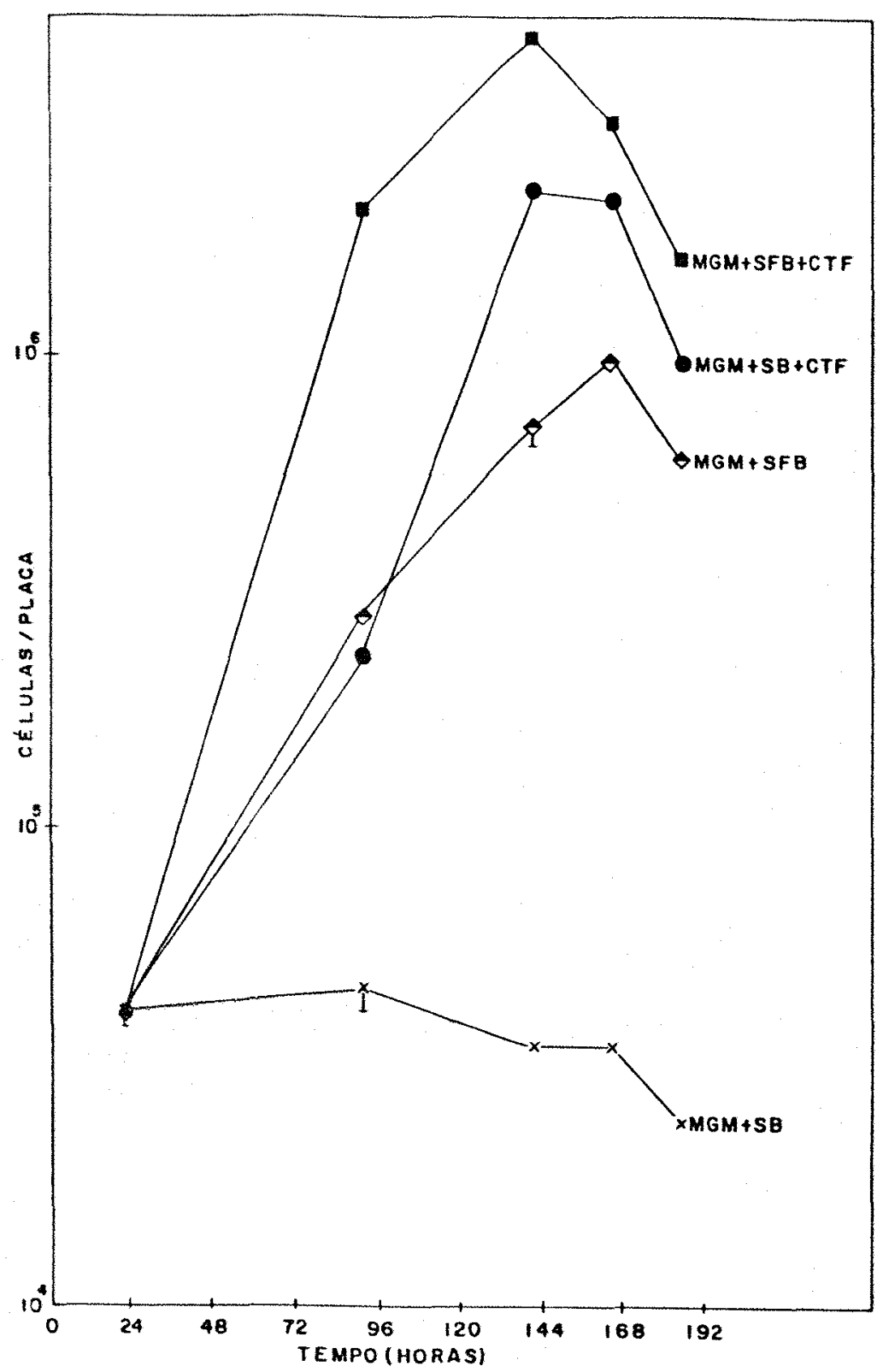

Figura 5 - Efeito de soros bovino e fetal bovino sobre o cresci mento de células BHK-21 mantidas em meio MGM suplementado com CTF-Difco. $\bigcirc M G M+8 \%$ SFB, MGM $+8 \%$ SFB + $10 \%$ CTF 01 fCo, $\longleftrightarrow$ MGM + 8\% 8B, - MGM $+8 \% 5 B+10 \%$ CTF-DifCo. 
Analisando as Figuras 4 e 5 percebe-se que os meios MEM e MGM atuam de maneira similar na proliferação de células BHK-21. Suplementação tanto de MEM como de MGM apenas com SFB permite o crescimento de células BHK, mas a suplemen tação com se apenas não é eficaz.

A adição de CTF propicia um grande efeito estimulatōrio do desenvolvimento celular, principalmente nas combinações de MEM ou MGM com SB.os valores de $T_{D}$ säo inferiores no melo MEM, principalmente quando combinado com SFB. Grande redução de $T_{D}$ e aumento de $D_{S}$ ocorrem quando CTF é adicionado aos meios suplementados com sB (ver Tabela 7). 


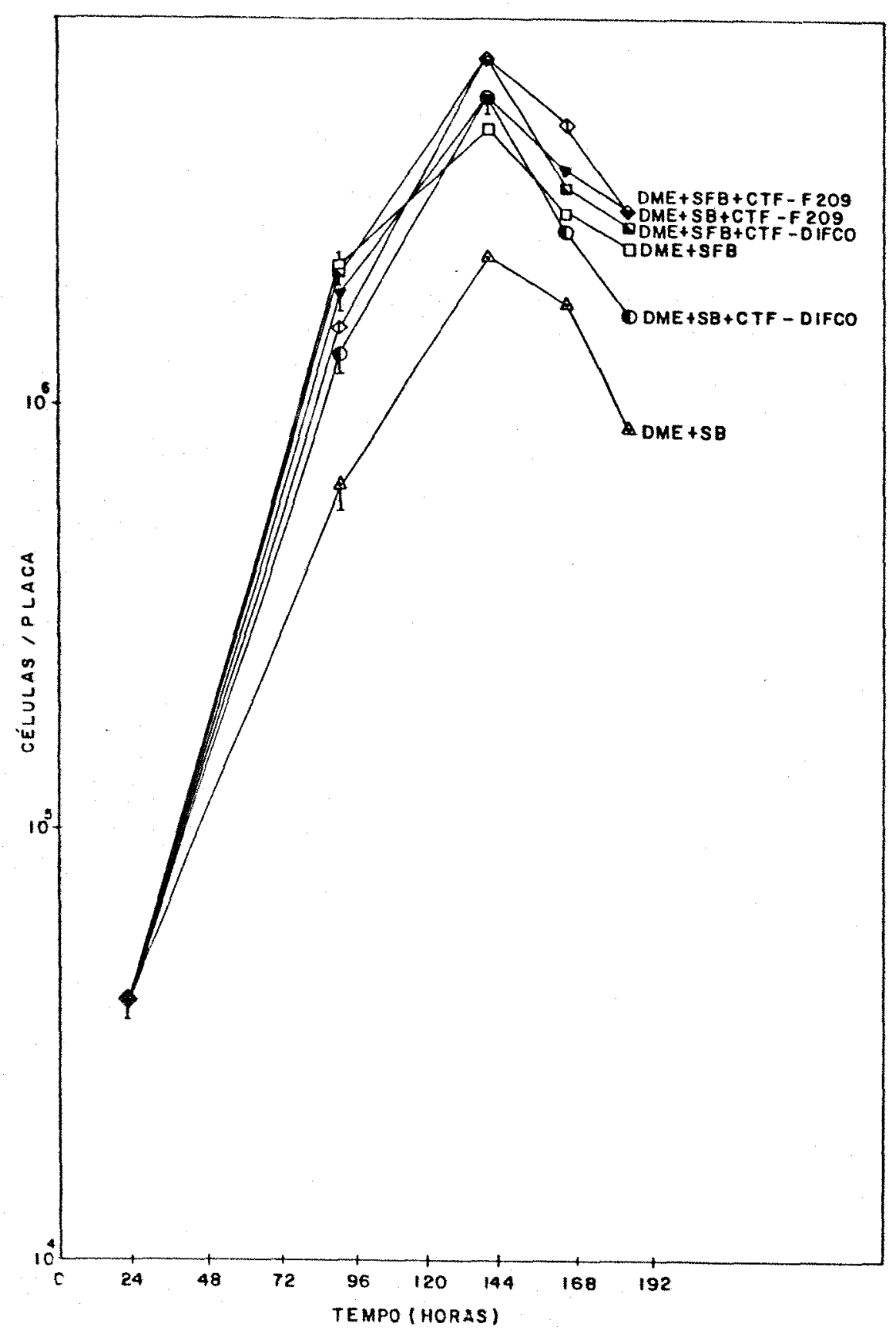

Figura 6 - Efeito da suplementação do meio DME com diferentes soros e CTFs na promoção de crescimento de células $B H K-21 . \square \square D M E+8 \% S F B ; \bowtie \square D E+8 \% S F B+10 \%$ $C T F-F 209 ; \square D M E+8 \% S F B+10 \% C T F-D i f C O: \triangle \Delta$ $\mathrm{DME}+8 \% \mathrm{SB} ; \mathrm{DME}+8 \% \mathrm{SB}+10 \% \mathrm{CTF}-\mathrm{F} 209 ; 0-\mathrm{O}$ $D M E+8 \% \mathrm{SB}+10 \%$ CTF-DifCo. 
Tabela 8 - Valores de $T_{D}$ e $D_{S}$ para cêlulas BHK-21 crescendo em meio minimo + $8 \%$ soro $+10 \%$ CTF.

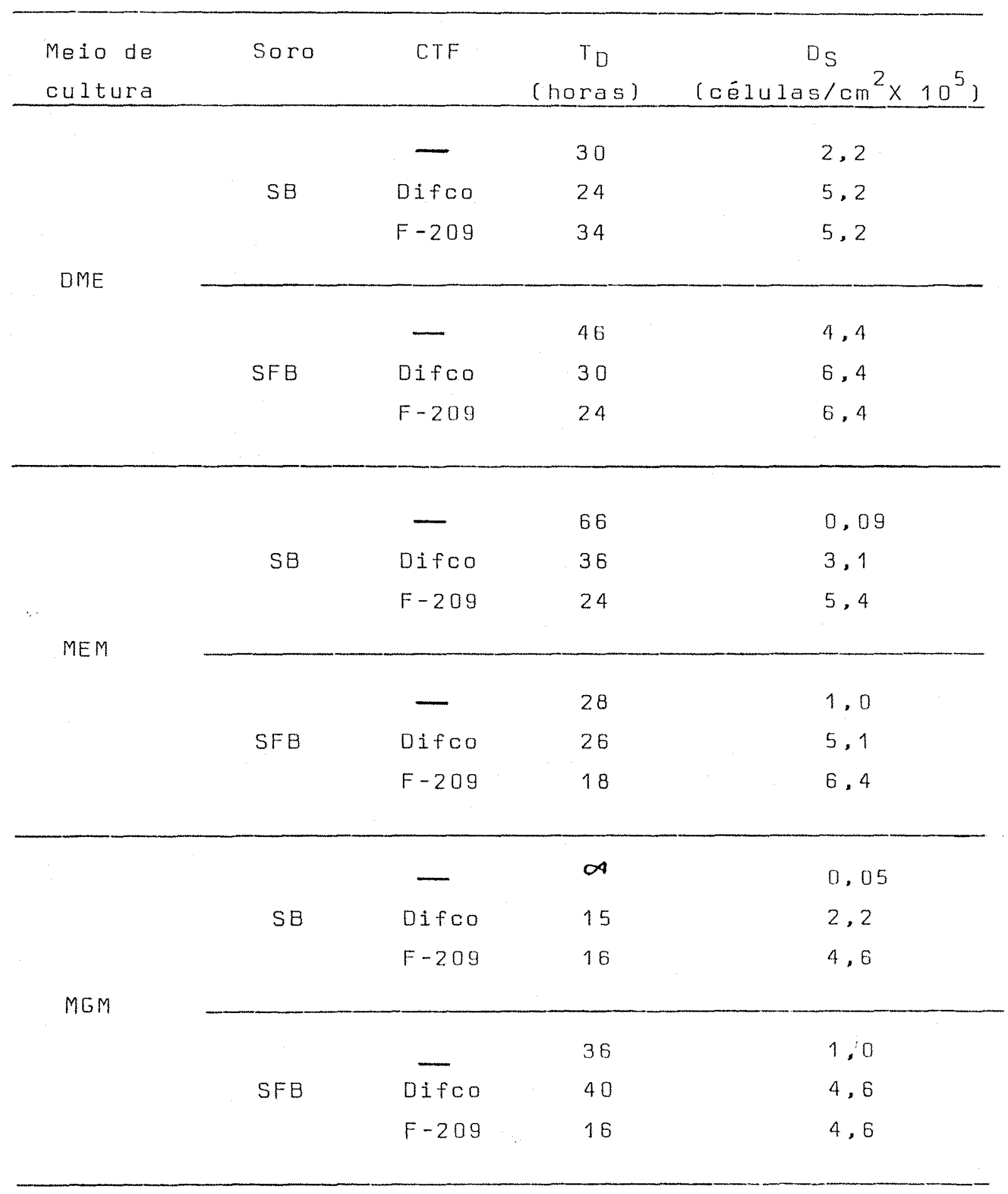


.59.

A suplementação do meio DME com SB ou SFB e diferentes amostras de CTF promove o crescimento de células BHK-21 de maneira semelhante, conforme mostra a Figura 6 . Os valores obtidos de $0_{S}$ foram semelhantes e os de $T_{D}$ menores para CTF-Difco na combinação DME + SB e para CTF-F209 na DME + SFB, segundo os dados da Tabela 8.

E importante ressaltar que a formulação utili zada na indústria de pradução de vacinas, por exemplo, $\vec{e}$ mui to semelhante ao MEM (ou MGM) sendo DME economicamente inviä vel.

Ao analisar as Figuras 7 e 8 nota-se que nos melos MEM ou MGM suplementados com CTF células BHK crescem melhor na presença de SFB do que de SB independentemente da amostra de CTF usada.Estas mesmas amostras apresentam resultados diferentes quando se trabalha com SB, notando-se que o CTF-F209 ë superior ao CTF-Difco na estimulação do crescimento das células, como pode ser verificado pelos resultados obtidos de $D_{S}$ e $T_{D}(T a b e l a \quad 8)$. 
.60.

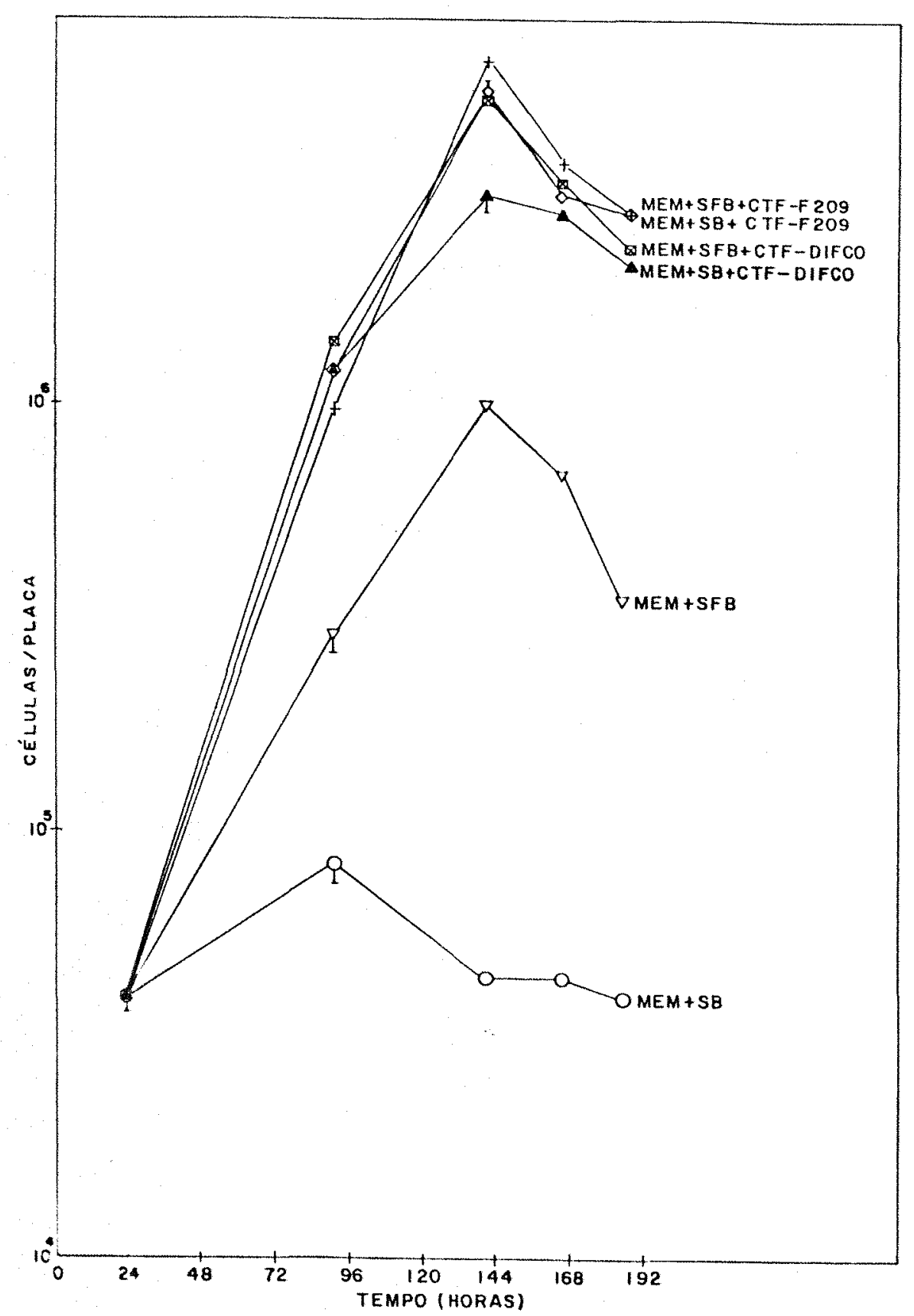

Figura 7 - Efeito da suplementação do meio MEM com diferentes soros e CTFs na promoção de crescimento de células $B H K-21 . \nabla \longrightarrow \nabla M E M+8 \% S F B ;+-+M E M+8 \% \mathrm{SFB}+$

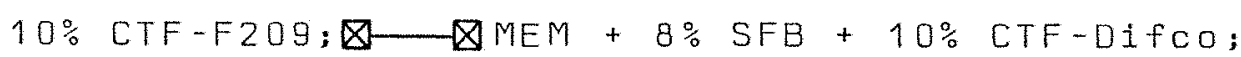
$O-O M E M+8 \% \mathrm{SB}: \bigcirc \mathrm{MEM}+8 \% \mathrm{SB}+10 \% \mathrm{CTF}-$ F209; MEM + $\triangle \mathrm{SB}+10 \% \mathrm{CTF}-\mathrm{DifCO}$. 
.61

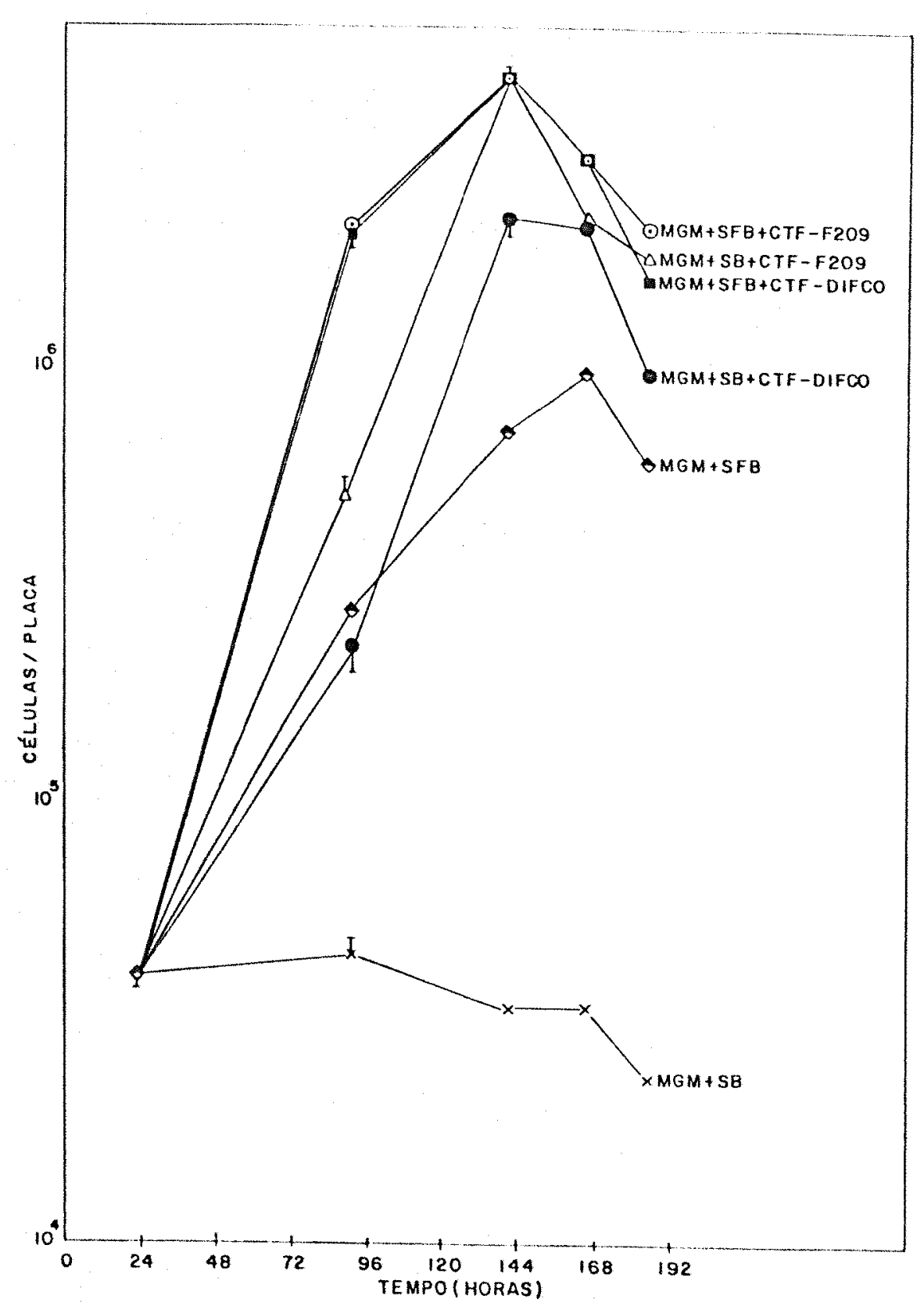

Figura 8 - Efeito da suplementação do meio MGM com diferentes soros e CTFs na promoção de crescimento de células $\mathrm{BHK}-21 . \bigcirc \mathrm{MGM}+8 \% \mathrm{SFB} ; \odot-\odot \mathrm{MGM}+8 \% \mathrm{SFB}+$ $10 \%$ CTF-F-209; MGM + 8\% SFB + 10\% CTF-DifCo; $\times \longrightarrow M G M+8 \% \mathrm{SB}: \triangle \triangle \mathrm{MGM}+8 \% \mathrm{SB}+10 \% \mathrm{CTF}-$ F-209; MGM + $8 \%$ SB $+10 \%$ CTF-DifCo. 
.62.

Os resultados apresentados até aqui mostram que o meio DME, sobretudo quando combinado com SFB, não ë adequado para avaliar a capacidade promotora de crescimento de CTF ou outros aditivos porque o crescimento basal é alto mascarando, assim, o efeito dos suplementos.o mesmo não ocor re com MEM ou MGM, pois estes dois meios permitem avaliar a ação do CTF e detectar diferenças entre as diversas amostras do produto (conforme mostra a Figura 9 ).

Entretanto, do analisar as amostras de CTF-fol e PPO70 nos meios MEM e MGM suplementados com SB, pode-se ve rificar que o meio MGM è mais eficiente na avaliação da atividade estimulatória do CTF (Figura 9). No meio MEM a estimulação da proliferação celular é semelhante para as amostras de CTF-PPZO e Difco, que apresentam valores bem präximos para $T_{D}$ e $D_{S}$, contrastando com o CTF-F01 que é bem inferior e mostra um $T_{D}$ muito elevado e uma $D_{S}$ baixissima (ver Tabela 9 ). Jä no MGM pode-se realmente perceber as variações existentes entre essas amostras : a inibição do crescimento celular pelas amostras de CTF-FO1 e PP7O $C_{D}=\infty$ e $D_{S}$ inferiares a $0.01 \times 10^{5} \mathrm{células} / \mathrm{cm}^{2}$ ) opõe-se à atividade estimulatóría do CTF-Difco ( $T_{D}=10$ horas $\left.\mathrm{e} \mathrm{D}_{\mathrm{S}}=0.8 \times 10^{5} \mathrm{células} / \mathrm{cm}^{2}\right)$ como mostram os dados da Tabela 9. 


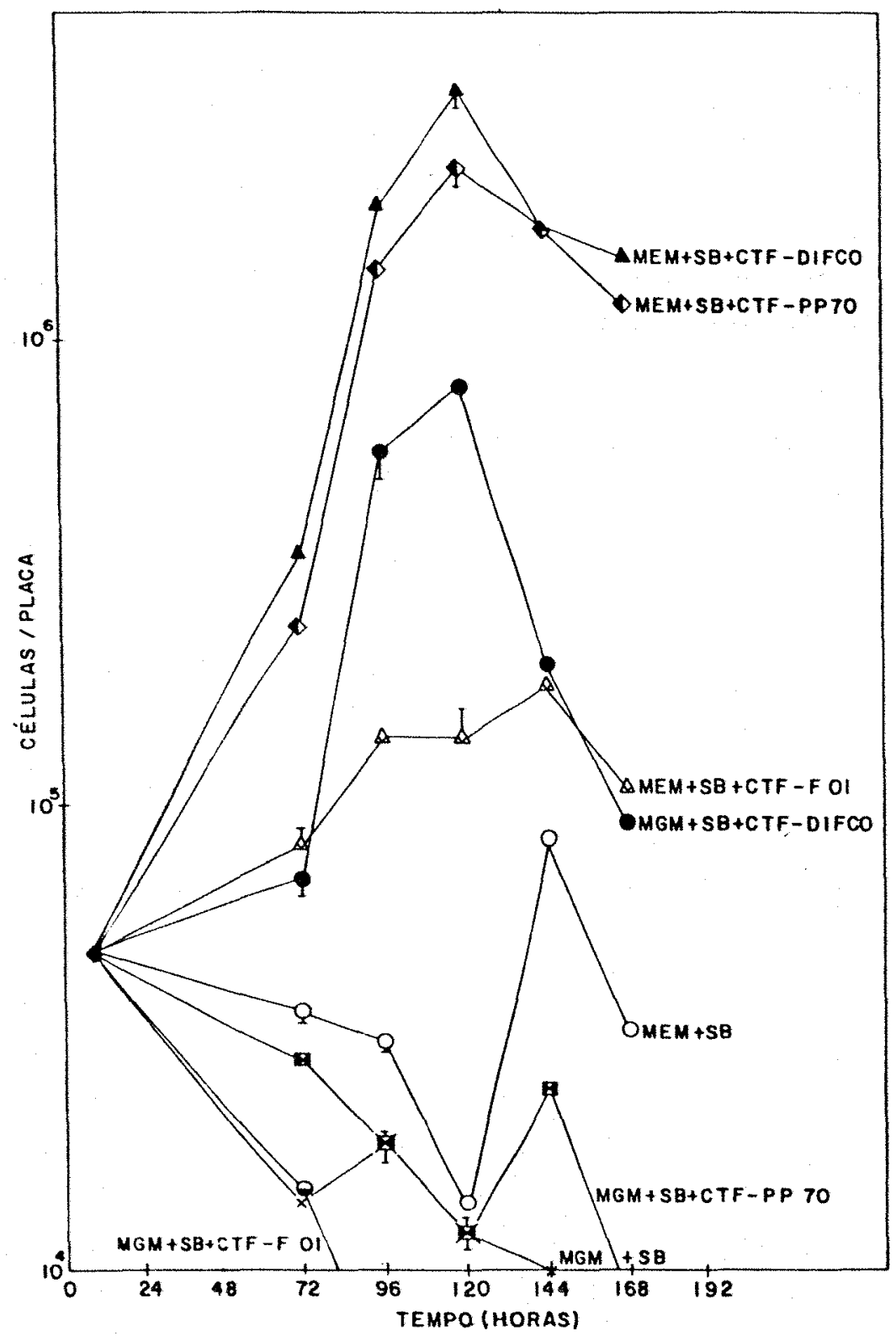

Figura 9 - Efeito dos meios MEM e MGM na avaliação da ativi dade mitogénica de diferentes amostras de CTF na promoção do crescimento de células BHK-21. $\longleftrightarrow$ X

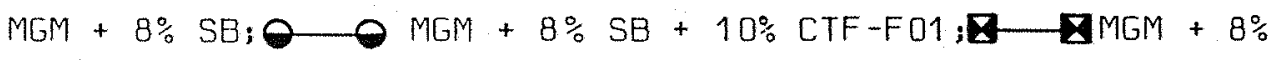
$\mathrm{SB}+10 \%$ CTF-PP70; $\mathrm{MGM}+8 \% \mathrm{SB}+10 \%$ CTF-DifCo:0-O $M E M+8 \%$ SB: $\triangle \triangle M E M+8 \% \mathrm{SB}+10 \%$ CTF-FO1; \MEM + $8 \% \mathrm{SB}+10 \%$ CTF-PP7 $; \sim \mathrm{MEM}+8 \% \mathrm{SB}+10 \% \mathrm{CTF}-\mathrm{DifCO}$. 
Tabela 9 - Valores de $T_{D}$ e $D_{S}$ para células BHK-21 crescendo em meio mínimo $+8 \% \mathrm{SB}+10 \%$ CTF.

\begin{tabular}{|c|c|c|c|}
\hline $\begin{array}{l}\text { Melo de } \\
\text { cultura }\end{array}$ & CTF & $\begin{array}{c}T_{0]} \\
(\text { horas })\end{array}$ & coélulas, cm $\left.{ }^{2} \times 10^{5}\right)$ \\
\hline \multirow{4}{*}{ MEM } & - & $\infty$ & 0,086 \\
\hline & F01 & 64 & 0.180 \\
\hline & PP7 0 & 10 & 2,300 \\
\hline & Difco & 10 & 3,400 \\
\hline \multirow{4}{*}{ MGM } & - & $\infty$ & 0.019 \\
\hline & F01 & $\infty$ & 0.015 \\
\hline & PP7 0 & $\infty$ & 0.029 \\
\hline & Difco & 12 & 0,800 \\
\hline
\end{tabular}

Portanto, a determinação de $T_{D}$ e $D_{S}$ através de curvas de crescimento em meio MGM suplementado com $8 \%$ de SB e $10 \%$ CTF mostrou-se um método bastante eficaz para ensaiar a capacidade promotora de crescimento de CTF. Tornou-se neces sário, porém, verificar se os resultados obtidos em monocamada eram aplicäveis tambẻm a células crescendo em suspensão líquida como são as culturas utilizadas na produção de vaci nas,por exemplo). 
4.2. Anälise do crescimento de cëlulas BHK-21 em suspensão liquida

4.2.1. Escala laboratorial

Células BHK-21 foram submetidas a crescimento em suspensão If́quida em frascos tipo "spinner", em condiçõestmeio, soro, inóculo de células, etcl que mimetizam aquelas utiliza das na indüstria, conforme descrito no item 3.6 .1 de Material e Métodos.os resultados obtidos com o melo MGM supiementado com SB e CTF encontram-se na Figura 10.

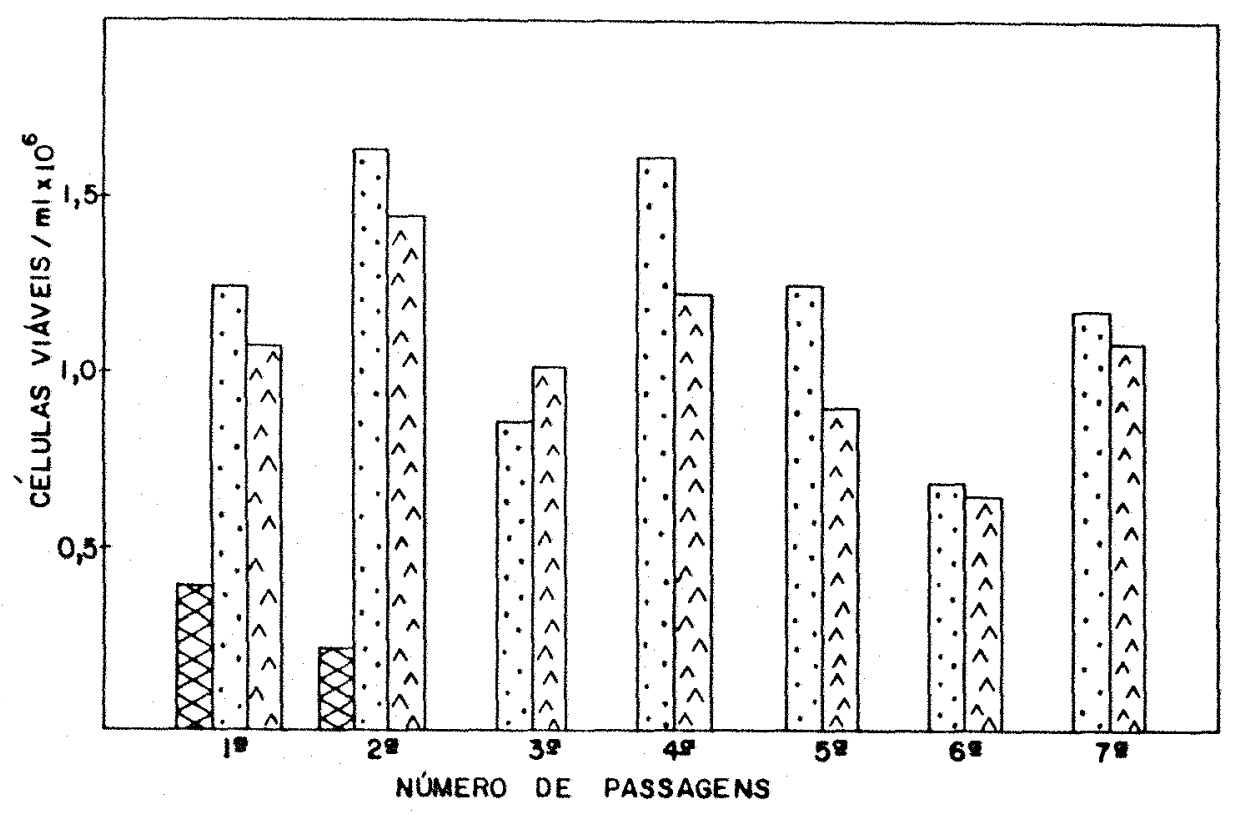

Figura 10 - Crescimento de células BHK-21 em suspensãolíquida (escala de laboratório) em meio MGM suplementado com $8 \% \mathrm{SB}+10 \% \mathrm{CTF}$. $M G M+S B+C T F-F 209 ; \hat{\Lambda} M G M+S B+C T F-D i f C o$. 
.66.

Nota-se que o meio MGM suplementado apenas com. SB não permite o crescimento das células e que o CTF F-209 é melhor que o CTF Difco.Aqui também está evidenciado que o CTF é um suplemento Importante a que as diferences entre as amostras de CTF também são detectadas nas culturas líquidas.

\subsubsection{Escala industrial}

Células BHK-21 foram submetidas a crescimento em suspensão líquida em escala industrial conforme descrito em Material e Métodos (ítem 3.6.2).0s resultados obtidos en contramrse nas figuras 11 e 12 .

A Figura 11 mostra o crescimento de células BHK em meio MGM suplementado com SB e CTF.Pode-se verificar - efeito inibidor do CTF-F01 sobre o orescimento de células BHK em oposição à atividade promotora de crescimento do CTFDífco e, numa proporção bem menor, à do CTF-PP7o. 


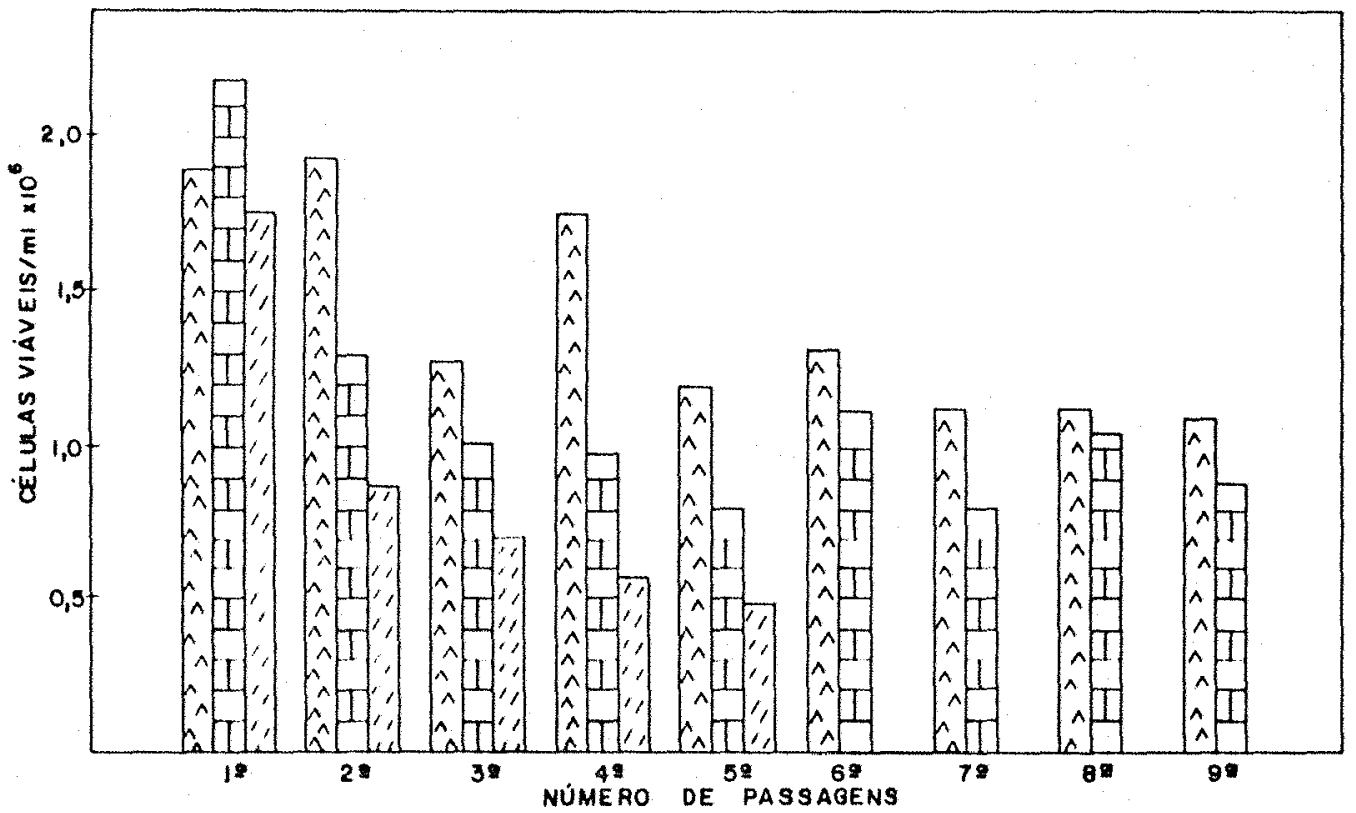

Figura 11 - Crescimento de células BHK-21 em suspensão líqui do (escala industrial) em meio MGM suplementado $\operatorname{com} 8 \% \mathrm{SB}+10 \% \mathrm{CTF}$. $\wedge \wedge^{\wedge}$ CTF-DifCo; EITFPP70; $\because \because:$ CTF-FO1.

Na Figura 12 pode-se comparar o crescimento de cëlulas BHK-21 em meio MGM suplementado com SB e diferentes CTFs.Nota-se que o CTF-F209 é mais eficiente na promoção do crescimento celular do que o CTF-Difco. 


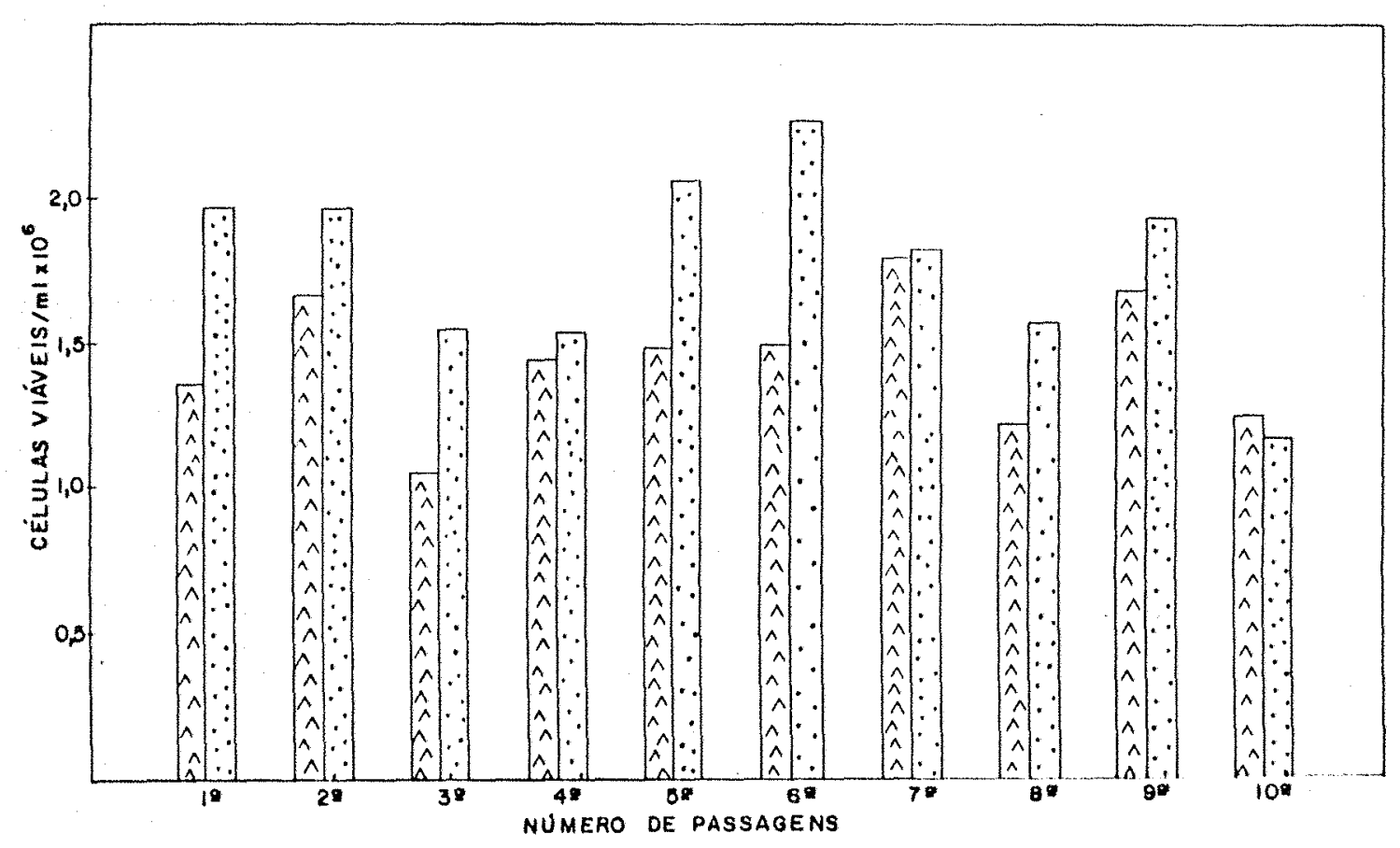

Figura 12 - Crescimento de células BHK-21 em suspensão líqui da (escala industrial) em meio MGM suplementado com $8 \% \mathrm{SB}+10 \%$ CTF. $\hat{\wedge}$ CTF-Difco: $\because \cdot$ CTF$F-209$.

$$
\text { Os resultados obtidos com células crescendo em }
$$
suspensão líquida reforçam aqueles do cultivo em monocamada: a) importância da suplementaçấo com CTF na proliferação de cé lulas BHK-21 e b) possibilidade de avaliação analítica da qua lidade do suplemento. 
4.3. Análise comparativa dos métodos de cultivo

As Figuras 13,14 e 15 apresentam os resultados de um ensalo comparativo dos métodos de cultivo em mono camada e em suspensão liquida. Neste ensaio procuroumse usar a mesma partida de meio MGM suplementado com SB para testar duas amostras de CTF e tambëm o efeito da suplementação adicional com hidrolisado de lactoalbumina (HL).

Pelo ensaio em monocamada notarse que o CTFF209 é melhor promotor da proliferação de células BHK do que - CTF-Merck (Figura 13) atingindo $D_{S}$ de 6,3 e $4.5 \times 10^{5}$ cálu las $/ \mathrm{cm}^{2}$, respectivamente.A suplementação do meio MGM + SB + CTF-F209 com hidrolisado de lactoalbumina, não melhorou o crescimento das células $C_{D}=20$ horas e $D_{S}=5,2 \times 10^{5}$ célu $1 a s / \mathrm{cm}^{2}$ ) como mostram os dados da Tabela 10. 


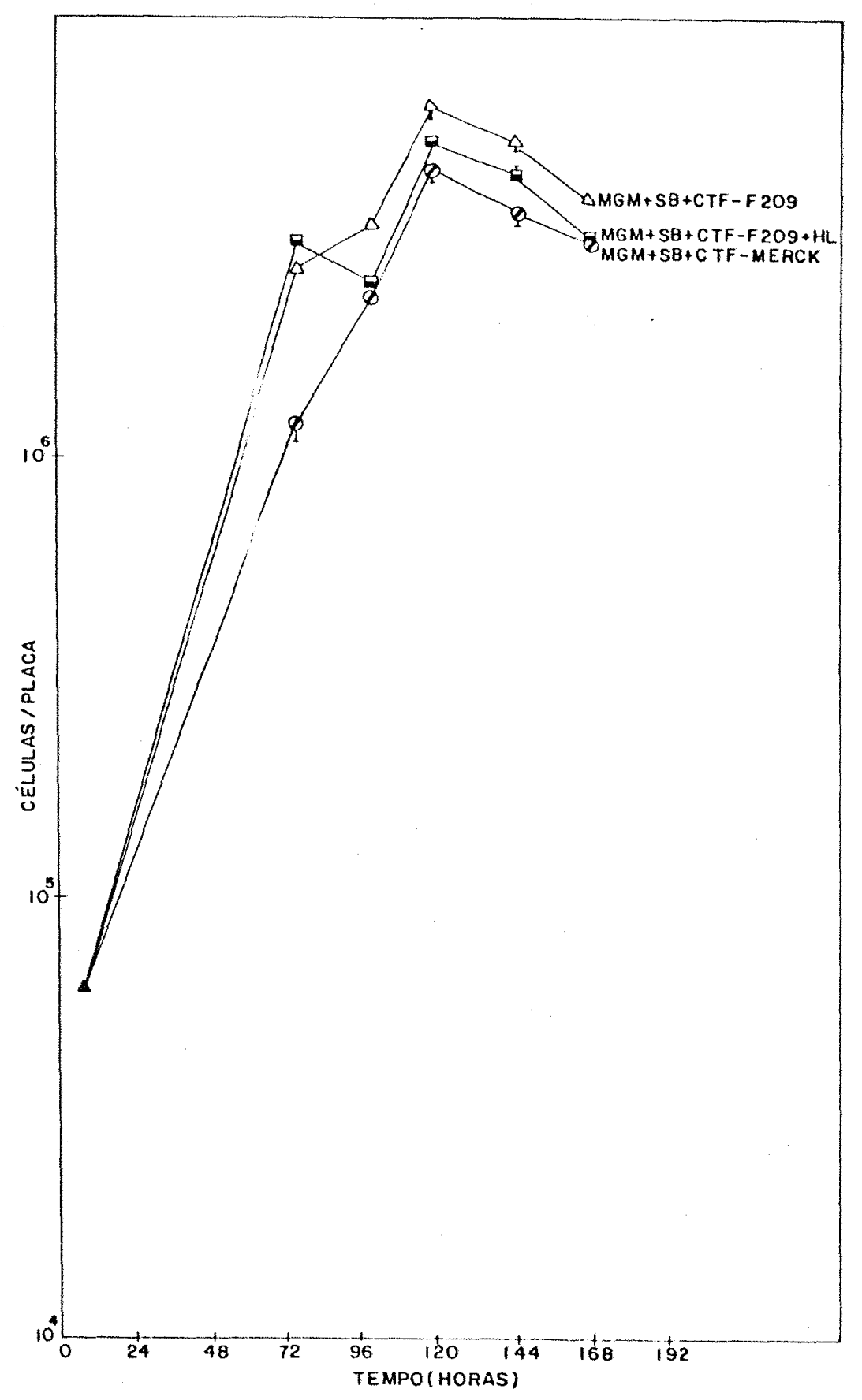

Figura 13 - Curvas de crescimento (monocamada) para células BHK-21 mantidas em meio MGM suplementado com $8 \%$ $\mathrm{SB}+10 \%$ CTF e $10 \% \mathrm{HL} \cdot \triangle \triangle \mathrm{CTF}-\mathrm{C}-209 ; \square \mathrm{CTF}-$ $\mathrm{F}-209+\mathrm{HL} ; \theta-0$ CTF-Merck. 
.71

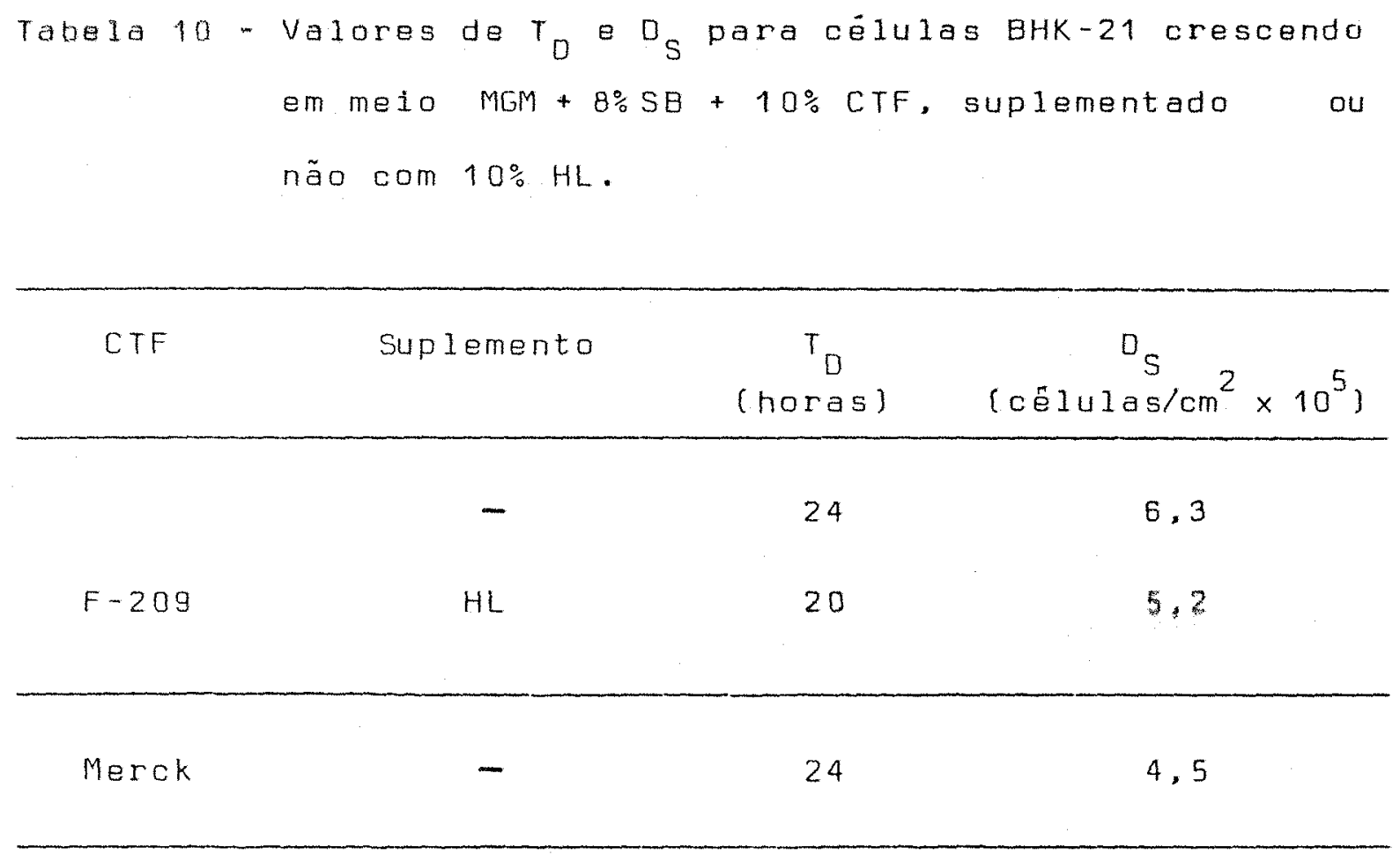




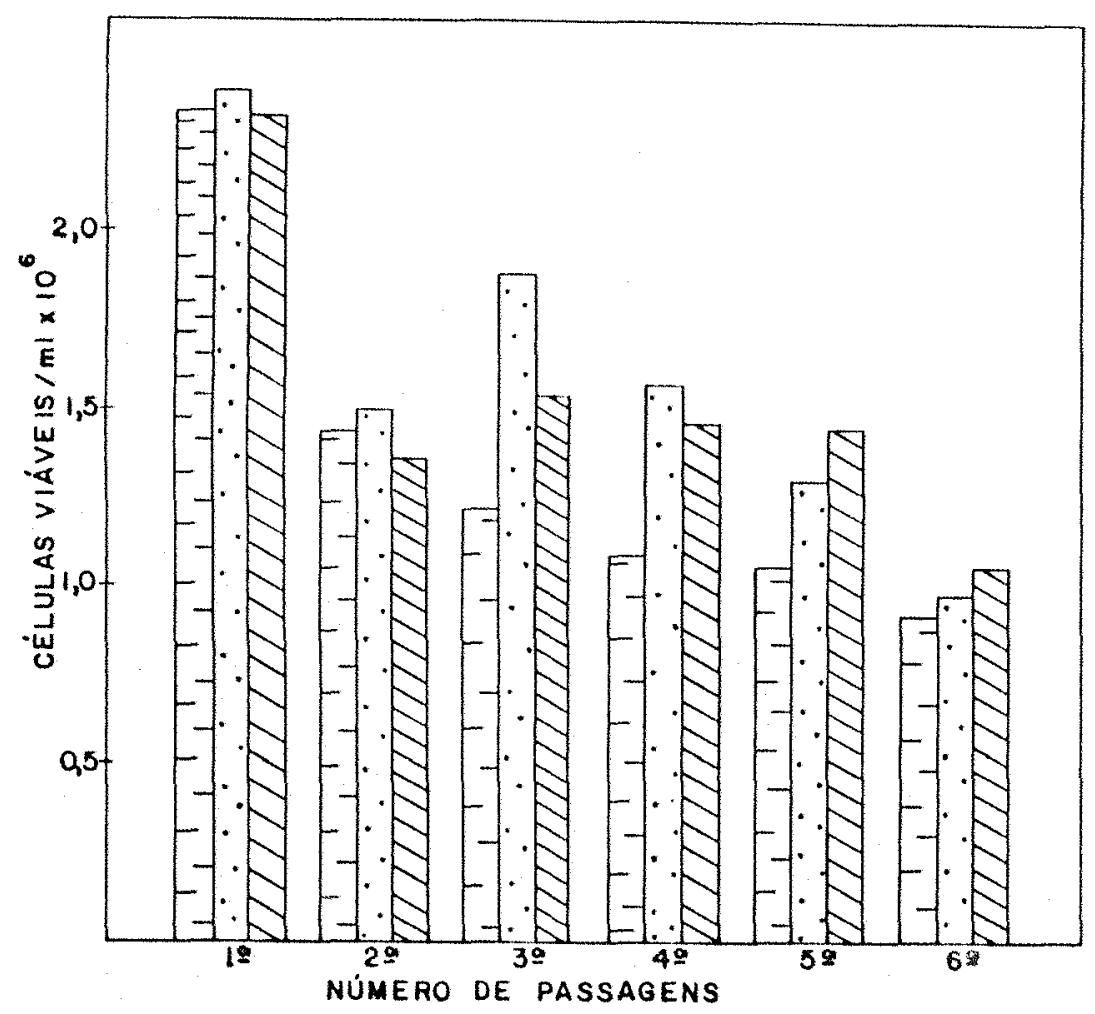

Figura 14 - Crescimento de cēlulas BHK-21 em suspensão líqui da (escala de laboratório) em mein MGM + $8 \% \mathrm{SB}+$ $10 \%$ CTF suplementado ou não com $10 \% \mathrm{HL}, \bar{E}$ CTFMerck: $\because$ CTF-F2O9; $\triangle$ CTF-F2O9+HL.

Os resultados obtidos com o cultivo em suspen são líquida em escala de laboratório (Figura 14) são semelhan tes aos de monocamada (Figura 13) ou seja : o CTF-F-2og foi superior em relaçáo ao CTF-Merck e a suplementação com hidroli- 
sado de lactoalbumina não teve efeito significativo.

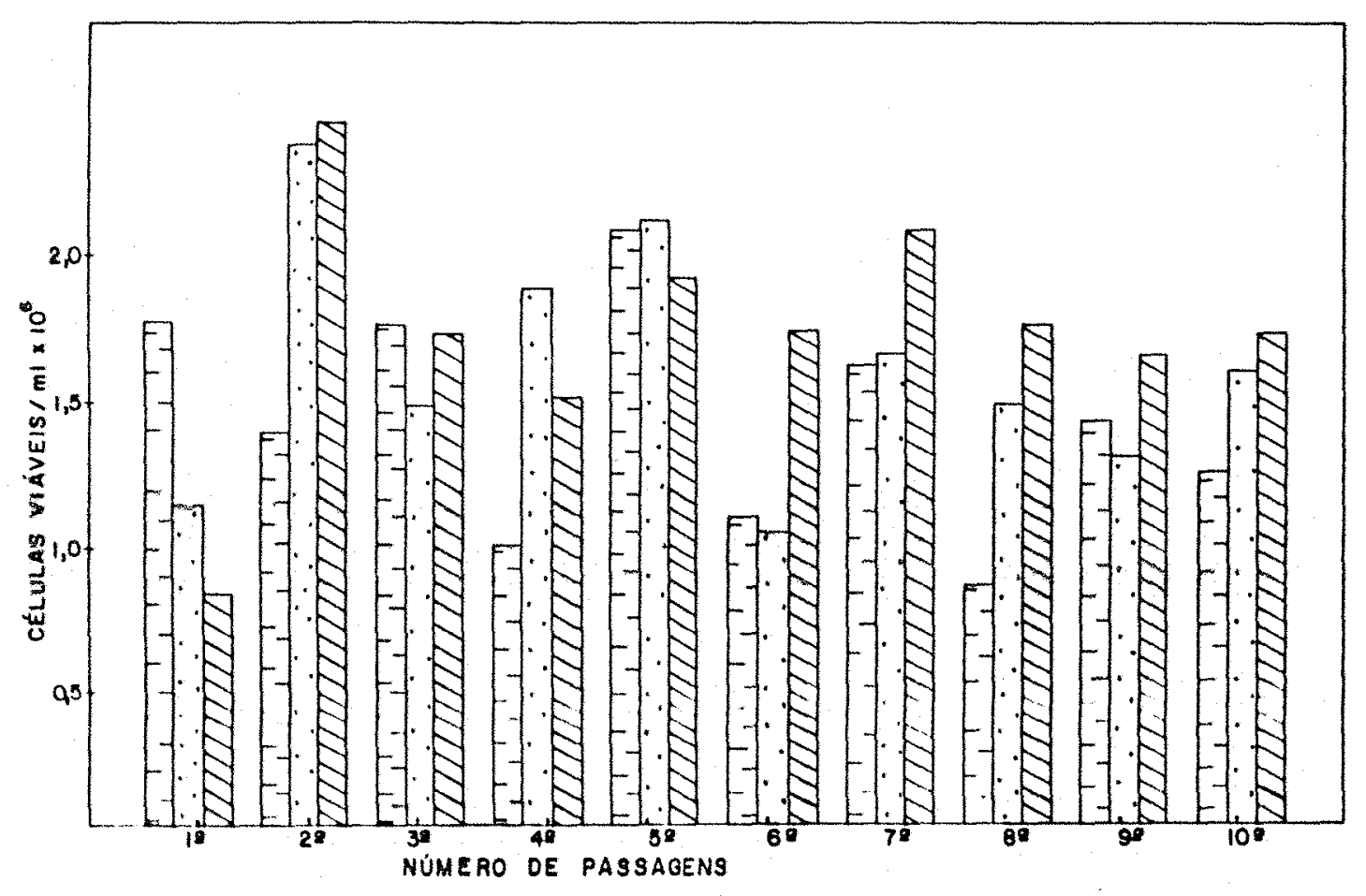

Figura 15 - Crescimento de células BHK-21 em suspensão líqui da (escala industrial) em meio MGM + $8 \% \mathrm{SB}+10 \%$ CTF suplementado ou não com 10\% HL. EJ CTFMerck; $\quad:$ CTF-F 209: $\$$ CTF -F $209+\mathrm{HL}$. 
Cëlulas BHK crescendo em suspensão líquida (escala industrial) praticamente não responderam à suplemen tação adicional com hidrolisado de lactoalbumina (Figura 15). Tanto meio suplementado apenas com SB + CTF quanto o meio com SB + CTF + HL têm o mesmo efeito na promoção do crescí mento dessas células.Além disso, o CTF-Merck não estimula a proliferação das células como o CTF-F 209 (Figura 15). Esses resultados confirmam os anteriores (Figuras 13 e 14 ) demons trando que é possivel testar os suplementas de meios de cuI tura em escala de laboratório, com tremenda economia.Na exe cução do ensaio em monocamada (curva de crescimento) são consumidos apenas $100 \mathrm{ml}$ do meio minimo, $8 \mathrm{ml}$ soro bovino e 0.3 g de CTF, enquanto que para o teste em escala industrial seriam necessários $5000 \mathrm{ml}$ do meio mínimo, $400 \mathrm{ml}$ soro bovino e $15,0 \mathrm{~g}$ de CTF. 
5. CONCLUSÕES

Dos resultados obtidos no presente trabalho podem ser tiradas as seguintes conclusões :

1. Diferentes meios de cultura e soros apresentam diferentes nlvale de atividade mitogennica, ou goja, promotora de crescimento de células BHK, sendo que DME suplementado com SFB representa a melhor condição para manutenção dessas células.Entretanto, DME e SFB não são economicamente viáveis na indústria, daf a necessidade de usar formulações semelhantes a MEM e MGM além de substituir SFB por $5 B$ e de introduzir um suplemento adicional (CTF).

2. CTF $\bar{e}$ um suplemento extremamente importante para a prol1feração de cếlulas BHK-21 principalmente quando o meio basal for menos rico (MEM, MGM) e o soro for bovino le não fetal bovinol. 
3. O ensaio de eficiência de plaqueamento, o primeiro ataque experimental adotado, não funcionou adequadamente para avaliar a atividade estimulatória do crescimento celular de CTF ou outros suplementos.

4. Meios de cultura e suplementos usados na produção industrial de vacinas podem ser testados em escala de laborató rio pela determinação de $T_{D}$ e $D_{S}$ através de curvas de crescimento em monocamada. Esse procedimento mostrou ser simples, de fácil execução, baixo custo e, acima de tudo, ca paz de mimetizar as condições industriais, reproduzindo, com excelente aproximação, os resultados obtidos na indûstria.

5. A determinação de $T_{D}$ e $D_{S}$ atravês de curvas de crescimento em meio MGM suplementado com $8 \%$ SB e $10 \%$ CTF mostrou-se um método bastante eficaz para o controle de qualidade dos suplementos de meios de cultura como CTF.Além de permitir - estudo dos fatores promotores de crescimento, esta meto .dologia oferece perspectivas concretas no sentido da eliminação do soro no cultivo das células BHK-21, tão importantes na produção de vacinas. 
.77

6. REFERENCIAS BIBLIOGRAFICAS

ARATHOON, W.R. e J.R.BIRCH, 1986.Large-scale cell culture in biotechnology. Science, 232:1390-1395.

ARMELIN, H.A., 1973,Pituitary extracts and steroids hormones in the control of 3 T3 cell growth. Proceedings of the National Academy of Sciences (USA), 70:2702-2706.

ARMELIN, H.A., 1975. Hormones and regulation of cell division: mammalian cell cultures as an experimental approach. In: LITWACK, G., Ed, Biochemical Actions of Hormones. New York, Academic Press, Vol.3, p.1-21.

ARMELIN, M.C.S., 1986. Biologia Molecular da Transformação Maligna. São Paulo, USP, Departamento de Bioquímica, 79 p. 
BARNES, D. E G.SATO, 1980. Methods for growth of cultured cells in serum-free medium. Analytical Biochemistry, 102:255-270.

BERMAN, P.W., T.GREGORY, D.CRASE E L.A.LASKY, 1985. Protection from genital herpes simplex virus type 2 infection by vaccination with cloned type 1 glycoprotein D. Science, 277: 1490-1492.

BETTGER, W.J., S.T.BOYCE, B.J.WALTHALL E R.G.HAM; 1981.Rapid clonal growth and serial passage of human diploid fibroblasts in a lipid-enriched synthetic medium supplemented with epidermal growth factor, insulin and dexamethasone. Proceedings of the National Academy of Sciences (USA), 78 : $5588-5592$

BIRCH, J.R., P.W.THOMPSON, K.LAMBERT E R.BORASTON, 1985. The large-scale cultivation of hybridoma cells producing monocional antibodies. In:FEDER. J. e W.R.TOLBERT, Ed. LargeScale Mammalian Cell Culture. Orlando, Academic Press, p. $1-16$

BOTTENSTEIN, J.E., 1983. Defined media and studies of growth factors. In:GuRofF, G, Ed.Growth \& Maturation Factors . New York, John Wiley \& Sons, vol.1, p.249-266. 
BOTTENSTEIN, J.E. e G.H.SATO, 1979.Growth of rat neuroblastoma cell line in serum-free supplemented medium. Proceedings

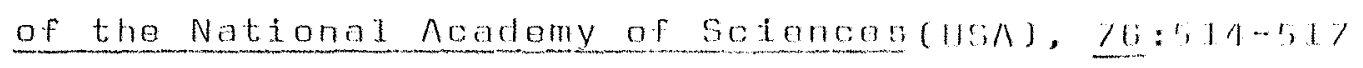

BOTTENSTEIN, J.E. e G.H.SATO, 1980.Fibronectin and polylysine requirement for proliferation of neuroblastoma cellsin defined medium. Experimental Cell Research, 129:361-366.

BOTTENSTEIN, J., I.HAYASHI, S.HUTCHINGS, H.MASUI, J.MATHER, D.B, MCCLURE, S.OHASA, A.RIZZINO, G.SATD, G. SERRERO, R.WOLFE e R.WU, 1979. The growth of cells in serumufree hormone supplemented media.In:JAKOBY, W.B. e I.H.PASTAN, Ed.Methods in Enzymology. New York. Academic Press, vol.58, p.94-109.

BURROWS, M.T., 1910.The cultivation of tissues of the chick embryo outside the body. Journal American Medical Association. 55:2057-2058.

BUYNACK, E.B. E M.R.HILLEMAN, 1966.Live attenuated mumps virus vaccine. 1-Vaccine development. Procegdings of the society for Experimenta1 Biology and Medicine, 123:768-774. 
.80.

BUYNACK, E.B., M.R.HILLEMAN, R.E.WEIBEL E J,STOKES, 1968, ,Live attenuated rubella virus vaccines prepared from duck embryo cell culture. Journal American Medical Association, 204:103108

CAPSTICK, P.B., A.J.GARLAND, R.C,MASTERS E W.G.CHAPMAN, 1966. Some functional and morphological alterations occurring during and after the adaptation of BHK-21 clone 13 cells to suspension culture. Experimental Cell Research. 44:119-128.

CAPSTICK, P.B., R.C.TELLING, W.G.CHAPMAN E D.L.STEWART, 1962. Growth of a cloned strain of hamster kidney cells in suspended cultures and their susceptibility to the virus of foot-and-mouth disease. Nature, 195:1163-1166.

CARREL, A., 1913. Artificial activation of the growth "In vitro" of connective tissues. The Journal of Experimental Medicine. $17: 14-19$.

CARREL. A., 1923. A method for the physiological study of tissues in vitro. The Journal of Experimental Medicine, 38:407-418.

CARREL, A.e M.T.BURROWS, 1910.Cultivation of adult tissues and organs autside of the body.Journal American Medical Association, 55:1379-1381. 
CARTWRIGHT, S.F., T.W.F.PAY E W.M.HENDERSON, 1957.Multiplication of the virus of foot-and-mouth disease in culture.journal of General Microbiology. 16:730-748.

CARTWRIGHT, T., 1987. Isolation and purification of products from animal cells. Trends in Biotechnology, 5:25-30.

CASTRO, M.P., 1964.Comportamento do vírus aftoso em cultura de células: smgceptibilidade da linhagem de células suinas IB-RS-2. Arquivos do Instituto Biológico, 31:63-78.

CHERINGTON, P.V., 1984.Regulation of fibroblast growth by multiple growth factors in serum-free media. In : MATHER, J.P., Ed.Mammalian cell culture. The use of serum-free hormonesupplemented media. New York, Plenum Press, p.17-52.

COHEN, S., 1962. Isolation of a mouse submaxillary gland protein accelerating incisor eruption and eyelid opening in the new-born animal. The Journal of Biological Chemistry, 237: $1555-1562$.

CORIELL, L.L.,1973. Detection, elimination and prevention of bacteria and fungi in tissue cultures. In: KRUSE, JR., P.F. e M.K.PATTERSON, JR., Ed.Tissue Culture: Methods and Applications. New York. Academic Press, p.718-721. 
DOEL, T.R., 1985.Prospects for improved foot and mouth disease vaccines. vaccine, $\underline{3}: 35-36$.

DULAK, N.C. \& H.M. TEMIN, 1973.A partlally purified polypeptide fraction from rat liver cell conditioned medium with multiplication-stimulating activity from embryo fibroblasts. Journal of Cellular Phys1ology. 81:153-160.

DULBECCO, R., 1952. Production of plaques in monolayer tissue cultures by single particles of an animal virus.Proceedings of the National Academy of Sciences (USA), 38:747-752

DULBECCO, R. \& G. FREEMAN, 1959.Plaque production by the polyoma virus. virology, $\underline{8}$ :396-397.

EAGLE, H., 1955a.Nutrition needs of mammalian cells in tissue culture. Science, 122:501-504.

EAGLE, H., 1955b. The specific amino acid requirements of a

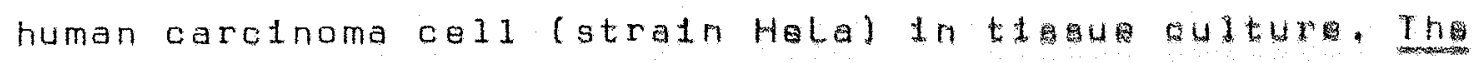
Journal of Experimental Medicine, 102:37-48.

EAGLE, H., 1959. Amino acid metabolism in mammalian cell cultures. Science, 130:432-437. 
EAGLE, H., 1971. Búffer combinations for mammalian cell culture. Science, 174:500-503.

EAGLE, H., 1973. The effect of environmental pH on the growth of normal and malignant celis. Journal of Lellular Physiology, $\underline{82: 1-8 .}$

EAGLE, H., V.I.OYAMA, M.LEVY e A.E.FREEMAN, 1957.myo-Inositol as an essential growth factor for normal and malignant human cells in tissue culture. The Journal of Biological Chemistry, 226:191-206.

EBELING, A.H., 1913.The permanent Iife of connective tissue outside of the organism. The Journal of Experimental Medicine, $17: 273-285$

ENDERS, J.F., T.H.WELLER E F.C.ROBBINS, 1949.Cultivation of the Lansing strain of poliomyelitis virus in cultures of various human embryonic tissues. Science, 109:85-87.

FISHER, H.W., T.T.PUCK e G.SAT0,1958.Molecular growth requirements of single mammalian cells: The action of fetuin in promoting cell attachment to glass.Proceedings of the Notional Academy of Sciences (USA), 44:4-10. 
FRENKEL, H.S., 1947.La culture du virus de la fievre aphteuse sur l'epithelium de la langue des bovides. Bulletin/Office International des Epizootios, 28:155-162.

FROESCH, E.R., J.ZAPF, E.RINDERKNECHT, B.MORELL, E.SCHOENLE e R.E.HUMBEL, 1979. Insulinlike growth factor (IGF-NSILA): structure, function and physiology. In:SATO, G.H. e R.ROSS, Ed. Hormones and Cell Culture. Cold Spring Harbor Conferences on Cell Proliferation. New York, Cold Spring Harbor Laboratory Press, vol.6, p.61-77.

GEY, G.0.. 1933. An improved technique for massive tissue culture. American Journal Cancer, 17:752-756.

GOSPODAROWICZ, D., 1974.Localisation of a fibroblast growth factor and its effect alone and with hydrocortisone on 3 T3 cell growth. Nature, 249:123-127.

GOSPODAROWICZ, D., K.L.JDNES E G.H.SATO, 1974.PUIIfication of a growth factor for ovarian cells from bovine pituitary glands. Proceedings of the National Academy of Sciences (USA), 71:2295-2299.

GRIFFITHS, J.B., 1985a.Cell biology:experimental aspects.In: SPIER, R.E. e J.B.GRIFFITHS, Ed.AnimaI Cell Biotechnology. orlando, Academic Press, vol.1, p.49-83. 
GRIFFITHS, J.B., 1985b.CeII products: an overview. In:SPIER, R.E. E J.B.GRIFFITHS, Ed.Animal CeIl Biotechnology. Orlando, Academic Press, vol.2, p.3-12.

GRIFFITHS, J.B. 1986 a. Can cell culture medium costs be reduced? Strategies and possibilities. Trends in Biotechnology, 4: 268272 .

GRIFFITHS, J.B., 1986 b.Scaling-up of animal cell cultures.In: FRESHNEY, R.I., Ed. Animal Cell Culture:A Practical Approach. oxford, IRL Press, p. 33-69.

GUILBERT, L.J. a N.N.ISCOVE, 1976. Partial replacement of serum by selenite, transferrin, albumin and lecithin in haemopoietic cel1 cultures. Nature, 263:594-595.

HALL, K. e K.UTHNE, 1971. Some biological properties of purified sulfation factor (SF) from human plasma. Acta Medica Scandinavica, 190:137-143.

HAM, R.G., 1963. An improved nutrient solution for diploid Chinese hamster and human cell lines. Experimental Cell Research, 29:515-526.

HAM, R.G., 1965.Clonal growth of mammalian cells in a chemically defined, synthetic medium. Proceedings of the National Academy of Sciences (USA), 53:288-293. 
.86.

HAM, R.G., 1982. Importance of the basal nutrient medium in the design of hormonaliy defined media. In:SATO, G.H. A.B.PARDEE e D.A.SIRBASKU, Fd. Growth of Cells in Hormonally Defined Media.Cold Spring Harbor Conferences on Cell Proliferatión. New York, Cold Spring Harbor Laboratory Press,vol.9,p.27-35.

HAM, R.G. e W.L.MCKEEHAN, 1979. Media and growth requirements. In: JACOBY, W.B.e I.H.PASTAN, Ed.Methods in Enzymology. New York, Academic Press, vol.58, p.44-93.

HARRIS, H. E J.F. WATKINS, 1965.Hybrid cells derived from mouse and man:Artificial heterokaryons of mammalian cells from different species. Nature, 205:640-646.

HARRISON, R.G., 1907.0bservations on the living developing nerve fibre. Proceedings of the Society for Experimental Biology and Medicine. 4 :140-143.

HAYASHI, I. e G.SATO, 1976. Replacement of serum by hormones permits growth of cells in a defined medium. Nature, 259:132-134.

HAYASHI, I., J.LARNER E G.SATO, 1978.HOrmonal growth control of cells in culture. In Vitro, 14:23-30. 
HAYFLICK, L., 1973.Screoning tissue cultures for mycoplasma infections.In:KRUSE, JR.,P.F. e M.K.PATTERSON, JR., Ed. T1ssue Culture: Methods and Applications. New York, Academic Press, p.722-728.

HIGUCHI, K.; 1973.Cultivation of animal cells in chemically defined media, a review. Advances in Applied Micrabiology. 16:111-136.

HILLEMAN, M.R., 1958. Efficacy of and indications for the use of adenovirus vaccine. American Journal Public Health, 48: $153-158$.

HILLEMAN, M.R., E.B.BUYNACK, R.E.WEIBEL, J,STOKES, J.E.WHITMAN e M.B.LeAGUS, 1968. Development and evaluation of the Moraten measles virus vaccine. Journal American Medical Association, $\underline{206}: 587-589$.

HOLLEY, R.W., 1974. Serum factors and growth control. In:CLARKSON, B. e R. BASERGA, Ed.Control of Proliferation in Animal Cells. Cold Spring Harbor Conferences on Cell Proliferation. New York, Cold Spring Harbor Laboratory Press, vol.1, $.13-18$.

HOLLEY, R.W. E J.A.KIERNAN, 1974. Control of the initiation of DNA synthesis in 3T3 cells: 10 -molecular-weight nutrients. Proceedings of the National Academy of Sciences (USA), 71:2942 - 
.88 .

HOLMES, R., 1967. Preparation from human serum of an alphaone protein wich Induces the 1 mmediate growth of unadapted cells in vitro. The Journal of Cell Blology, 32:297-308.

HÖÖK, M., K.RUBIN, A.OLDBERG, B, B̈BRINK e A.VAHERI, 1977. Cold-insoluble globulin mediates the adhesion of rat liver cells to plastic petri dishes. Blochemical and Biophysical Research Communications, 79:726-733.

HUTCHINGS, S.E. e G:H.SATO, 1978. Growth and maintenance of Hela celis in serum-free medium supplemented with hormones. Proceedings of the National Academy of Sciences (USA), 75 : $901-904$

ISCOVE, N.N, e F.MELCHERS, 1978. Complete replacement of serum by albumin, transferrin and soybean lipid in cultures of lipopolysaccharide-reactive $B$ Iymphocytes. The Journal of Experimental Medicine, 147:923-933.

JARVIS, A.P. E T.A.GRDINA, 1983.Production of Blologicals from microencapsulated living cells. Biotechniques, 1:2227. 
KARKARE, S.B., P.G.PHILLIPS, D.H.BURKE E R.C.DEAN, JR.,1985. Continuous production of monoclonal antibodies by chemostatic and immobilized hybridoma culture.In :FEDER, J. e W.R.TOLBERT, Ed.Large-Scale Mammalian Cell Culture.Orlando, Aoademic Press, p.127-149.

KATSUTA, H. e T.TAKAOKA, 1973. Cultivation of celis in protein and lipid-free synthetic media.In:PRESCOTT,D.M., Ed.Methods in Cell Biology. New York. Acodemic Press, vol.6. p.1-42.

KEAY, L., 1975. Autoclavable low cost serum-free cell culture media. The growth of $L$ celis and BHK cells on peptones. Biotechnology Bioengineering, 17:745-764.

KNAZEK, R.A., P.M.GUILLINO, P.O.KOHLER E R.L.DEDRICK, 1972. Cell culture on artificial capillaries:an approach to tissue growth in vitro. Science, 178:65-66.

KOHLER, G e C.MILSTEIN, 1975. Continuous cultures of fused cells secreting antibody of predefined specificity. Nature, 256: $495-497$.

KOHLER, N. e A.LIPTON, 1974.Platelets as a source of fibroblast growth-promoting activity. Experimental Cell Research, 87: $297-301$ 
KU, K., M.J.KUO, J.DELENTE, B.S.WILDE e J.FEDER, 1981. Development of a hollow-fibre system for large scale culture of mammalian cells. Biotechnology Bioenginegring. 23:79-95.

LAMBERT, K.J. e J.R.BIRCH, 1985.Cell growth media. In:SPIER, R.E. e J.B.GRIFFITHS, Ed. Animal Cell Biotechnology.Orlando, Academic Press, vol.1, p.85-122.

LEOF, E.B., W.WHARTON, J.J.VAN WYCK E W.J.PLEDGER, 1982 .Epidermal growth factor (EGF) and somatomedin C regulate G1 progression in competent BALB/C-3T3 cells. Experimental Cell Research, $141: 107-115$

LEVI-MONTALCINI, R. e P.U.ANGELETTI, 1968, Nerve growth factor. Physiological Reviews, 48:534-550

LEWIS, W.H. e M.R.LEWIS, 1912. The cultivation of chick tissues in media of known chemical constitution. The Aratomical Record, $\underline{6}: 207-211$.

LYNN, J.D. e R.T.ACTON, 1974.0esign of a large-scale-mammalian cell, suspension culture facility. Biotechnology Bioengineering, $17: 659-673$ 
MACIAG, T., B.KELLY, J.CERUNDOLO, S.ILSLEY, P.R.KELLEY, J. GAUDREAU e R.FORAND, 1980. Hormonal requirements of baby hamster kidney celis in culture.Cel1 Blology International Reports, $4: 43-50$.

MACPHERSON, I., 1963.Characteristics of a hamster celi clone transformed by polyoma virus.Journal of National Cancer Institute, 30:795-815.

MACPHERSON, I. E M.STOKER, 1962.POlyoma transformation of hamster coll clones-an investigation of genetic factors affecting cell competence. Virology, 16:147-151.

MAITLAND, H.B. e M.C.MAITLAND, 1928.CuItivation of vaccinia virus without tissue culture. Lancet, 215:596-597.

MANUAL GIBCo (Grand Island Biological Company), 1974. Madison.

MATHER, J.P. E G.H.SATU, 1978.Hormones and growth factors in cell culture: problems and perspectives. In:FEDEROFF, S. e L.HERTZ, Ed.Cell, tissue and organ cultures in neurobiology. New York, Academic Press,p.619-630.

MATHER, J.P. E G.H.SATO, 1979.The growth of mouse melanoma cells in hormone-supplemented serum-free medium.Experimental CRII Research, 120:191-200. 
MoGARRITY, G.J., 1979.Detection of contamination. In: JACOBY, W.B. E I.H.PASTAN, Ed.Methods in Enzymology. New York, Academic Press, vol.58, p.18-28.

MCKEEHAN, W.L., K.A.MCKEEHAN, S.L.HAMMOND E R.G.HAM, 1977 . Improved medium for clonal growth of human diploid fibroblasts at low concentrations of serum protein. InVitro, 13:399-416.

MoLIMANS, W.F., 1979.Mass culture of mamalian cells. In: JACOBY, W.B. e I.H.PASTAN,Ed. Methods in Enzymology, New York, Academic Press, vol.58, p.194-211.

MEDAWAR, P.B., 1941. Sheets of pure epithelium from human skin. Nature, 148:783.

MEIGNIER, B.,1979.CeII culture on beads used for the industrial production of foot-ard-mouth disease virus. Developments of Biological Standardization, 42:141-145.

MEIGNIER; B., A.MANGEOT, H.FAVRE, 1981.Foot and mouth disease virus production on microcarrier grown cells. Qevelopments of Biological standardization, 46:249-256.

MIZRAHI, A., 19.77.Primatone RL in mammalian cell culture media. Biotechnology Bioengineering, 19:1557-1561. 
MIZRAHI, A., 1986a.Production of biologicals from animal cells - an overview.Process Biochemistry, 21:108-112.

MIZRAHI, A., 1986b.Biologicals from animal cells in culture. Biotechnology, 4: $123-127$.

MIZRAHI, A. e A.AVIHOO,1976. A simple and cheap medium for BHK cells in suspended cultures.Journal of Biological Standardization, $4: 51-56$.

MORGAN, J.F., H.J.MORTON E R.C.PARKER, 1950.Nutrition of animal cells in tissue culture.I. Initial studies on a synthetic medium. Proceedings of the society for Experimental Biology and Medicine, 73:1-8.

MORTON, H.J. \& J.F.MORGAN, 1973.Sample preparations of media. A. Vertebrate CeIIs.In:KRUSE, JR., P.F. e M.K. PATTERSON. JR., Ed. Tissue Culture:Methods and Applications. New York, Academic Press, p.686-692.

MOSCONA, H. E A.MOSCONA, 1952. The dissoclation and aggregation of cells from organ rudiments of the early chick embryo. Journal of Anatomy, 86:287.

MOWATT, G.W. B W.G.CHAPMAN, 1962.Growth of foot-and-mouth disease virus in a fibroblastic cell line derived from hamster kidneys. Nature, 194:253-255. 
OKADA, Y. e F.MURAYAMA, 1965.Multinucleated giant cell formation by fusion between cells of two different strains. Experimental Cell Research, 40:154-158.

PARKER, F.JR. e R.N.NYE, 1925.Studies on filterable viruses. I.Cultivation of vaccine virus. American Journal of Pathology. $1: 325-335$

PATTERSON, M.K.JR., 1979. Measurement of growth and viability of cells in culture. In: JAcoBY, W.B. e I.H.PASTAN,Ed. Methods in Enzymology. New York, Academic Press, vol.58, p.141-152.

PATTY, R.E., H.L.BACHRACH E W.R.HESS, 1960.Growth of footand-mouth disease virus in bovine kidney cell suspensions. American Journal in Veterinary Research, 21:144-149.

PHILLIPS, A.W., G.D.BALL, K.H.FANTES, N.B.FINTER E M.D.JOHNSTON, 1985. Experience in the cultivation of mammalian cells on the 80001 scale.In:FEDER, J. e W.R.TOLBERT, Ed. LargeScale Mammalian Cell Culture. Orlando. Academic Press,p.8795.

PLEDGER, R.A., 1961.Formation and release of foot-and-mouth disease virus from bovine calf kidney cell cultures. Virology, 13:365-367. 
PLEQGer, W.J., C.D.STILES, H.N.ANTONIAdES E C.D.SCHER, 1977. Induction of DNA synthesis in BaIb/c-3T3 cells by serum components : reevalution of the commitment processiproceedings of the National Academy of Sciences(USA), 74:4481-4485.

PUCK, T.T. B P.I.MARCUS, 1955. A rapid method for viable cell titration and clone production with HeLa cells in tissue culture: the use of $x$-frradtated cells to supply candt tonfing factors. Proceedings of the National Academy of Sciences (USA), 41: $432-437$.

PUMPER, R.W., 1973.Purification and standardization of water for tissue culture. In:KRUSE, JR., P.F. e M,K.PATTERSON,JR., Ed. Tissue Culture:Methods and Applications, New York, Academic Press, p.674-677.

RADLETT,P.J., R.C.TELLING, C.J.STONE E J.P.WHITESIDE, 1971. Impnovements in the growth of BHK-21 cells in submerged culture. Applied Microbiology, 22:534-537.

RADLETT, R.J., R.C.TELLING, J.P.WHITESIDE E M.A.MASKELL, 1972. The supply of oxygen to submerged cultures of BHK-21 cells. Biotechnology Bioengineering, 14:437-445. 
RATAFIA, M., 1987a. Issues in mammalian cell culture production. Pharmaceutical Technology, 11:48-56.

RATAFIA, M., 1987b.Mammalian cell culture:worldwide activities and markets. Biotechnology, 5:692-694,

RINALDINI, L.M., 1954. A quantitative method for growing animal cells in vitro. Nature, 173:1134-1135.

RINDERKNECHT, E. E R.E.HUMBEL, 19.76, Polypeptides with nonsuppressible insulin-like and cell-growth promoting activities in human serum:isolation, chemical characterization and some biological properties of forms I and II. Proceedings of the National Academy of Sctences (USA), 23:2365-2365.

RIZZINO, A., H.RIZZINO E G.SATO, 1979,Defined media and the determination of nutritional and hormonal requirements of mammalian cells in culture, Nutrition Reviews, 37: 369-378.

ROCKWELL, G.A., G.H.SATO E D.B.MCCLURE, 1980, The growth requirements of SV40 virus-transformed Balb/c-3T3 cells in serum-free monolayer culture.Journal of Cellular Physiology, $103: 323-331$. 
ROSS, R., J.GLOMSET, B.KARIYA e L.HARKER, 1974. A plateletdependent serum factor that stimulates the proliferation of arterial smooth musole cells in vitro.proceedings of the National Academy of Sciences (USA), 71:1207-1210.

ROUS, P. e F.S.JONES, 1916. A method for obtaining suspensions of living cells from the fixed tissues for the plating out of individual cells. The Journal of Experimental Medicine, $23: 549-555$.

RUDLAND, P.S., H.DURBIN, D.CLINGAN E L.JIMENEZ DE ASUA,1977. Iron salts and transferrin are specifically required for cell division of cultured $3 T 3$ celis. Blochemical and Biophysical Research Communications, 75:556-562.

SANFORD, K.K.. W.R.EARLE e G.D.LTKELY, 1948.The growth" in vitro" of single isolated tissue cells.Journal of the National Cancer Institute, $9: 229-246$.

SATO, G., 1975. The role of serum in cell culture.In:LITWAK, G., Ed.Biochemical Action of Hormones. New York. Academic Press, VoI.3, p.391-396.

SCHEIRER, W. 1987. Laboratory management of animal cel1 culture processes. Trends in Biotechnology, $\underline{5}: 261-265$, 
SCHERER, W.F., J.T.SYVERTON E G.O.GEY, 1953.Studies on the propagation in vitro of poliomyelitis viruses. VI - Viral multiplication in a stable strain of human malignant epithelial cells (strain HeLa) derived from an epidermoid carcinoma of the cervix. The Journal of Experimental Medicine: 97: $695-710$

SELLERS, R.F., 1955.Growth and titration of the viruses of foot-and-mouth disease and vesicular stomatitis in kidney monolayer tissue cultures. Nature, 176:547-549.

SHIPLEY, G.D. e R.G.HAM, 1983.Multiplication of Swiss 3T3 cells in a serum-free medium. Experimental Cell Research, $146: 249-260$.

SIMMS, H.S. e N.P.STILLMAN, 1937. Substances affecting adult tissue in vitro.I - The stimulating action of trypsin on fresh adult tissues. The Journal of General Physiology, 20: $603-619$.

SPIER, R.E., 1980.Recent developments in the large scale cultivation of animal cells in monolayers. Advances in Biochemical Engineering, 14:119-162.

SPIER, R.E., 1982. Animal cell technology; an overview. Journal Chemical Technology Biotechnology, 23:304-312. 
SPIER, R.E., 1983.Production of veterinary vaccines. In:MIZRAHI. A. e A.L.VAN WEZEL, Ed. Advances in Biotechnological Processes. New York, Alan R.Liss Inc., vol, 2, p.33-59.

SPIER, R., 1988. Animal cells in culture :moving into the exponential phase. Trends in Biotechnology, $\underline{6}: 2-6$.

SPIER, R.E. E F.HORAUD, 1985.The biotechnological future of animal celis in culture.In:SPTER, R.E. e J.B.GRIFFITHS.Ed. Animal Cell Biotechnology.orlando. Academic Press, vol.2, p. $431-458$.

SPIER, R.E. e J.P.WHITESIDE, 1976a.The production of foot and mouth disease virus from BHK 21 C13 cells grown on the surface of glass spheres. Biotechnology Bioengineering, 18:649-657.

SPIER, R.E. E J.P.WHITESIDE, 1976b.The production of foot-and mouth disease virus from BHK 21 C13 cells grown on the surface of DEAE-Sephadex A50 beads. Biotechnology Bioengineering, $18: 659-667$

SPORN, M.B. e G.J.TODARO, 1980.Autocrine secretion and malignant transformation of cells. The New England Journal of Medicine, $303: 878-880$. 
STEINHARDT, E., E.ISRAELI e R.A.LAMBERT, 1913.Studies on the cultivation of the virus of vaccinia. The Journal of Infectious Diseases, 13:294-300.

STILES, C.D., G.T.CAPONE, H.N.ANTONIADES, J.J.VAN WYCK E W.J. PLEQGER, 1979. Dual control of cell growth by somatomedins and platelet-derived growth factor. Proceedings of the National Academy of Sciences (USA), 76:1279-1283.

STOKER, M. e I.MACPHERSON, 1964.Syrian hamster fibroblast cell Iine BHK21 and its derivatives. Nature, 203:1355-1357.

TELLING, R.C., 1969.Foot and mouth disease vaccine. Process Biochemistry, $4: 49-52$.

TELLING, R.C. E P.J.RADLETT, 1971. Large scale cultivation of mammalian cells. Advances in Applied Microbiology, 13:91-119.

TELLING, R.C. e R.ELSWORTH, 1965.Submerged culture of hamster kidney cells in a stainless steel vessel. Blotechnology Bioengineering, 2 2:417-434.

TEMIN, H.M. e H. RUBIN, 1958. Characteristics of an assay for Rous sarcoma virus and Rous sarcoma cells in tissue culture. Virology, $\underline{6}: 669-688$. 
TOLBERT, W.R. e J.FEDER, 1983.Large scalecell culture technology. Annual Reports on Fermentation Processes, 6:35-74.

TOMEI, L.D. e C.J.ISSEL, 1975.Growth and immunogenicity of foot-and-mouth disease virus in baby hamster kidney cells adapted to and continuously grown in a serum-free chemically defined media. Biotechnology Bioengineering, 17:765-778.

VAN WEZEL, A.L. E C.A.M.VAN DER VELDEN-de GROOT, 1978. Large scale cultivation of animal cells in microcarrier culture. Process Biochemistry, 13:6-8.

VAN WYCK, J.J., K.HALL, J.L.VAN DER BRANDE E R.P.WEAVER, 1971. Further purification and characterization of sulfation factor and thymidine factor from acromegalic plasma. Journal of Clinical Endocrinology, 32:389-396.

WALTHALL, B.J. e R.G.HAM, 1981.Multiplication of human diploid fibroblasts in a synthetic medium supplemented with EGF, insulin and dexamethasone. Experimental CeII Research, 134: $303-311$.

WAYMOUTH, C., 1973.Determination and survey of osmolality in culture media.In:KRUSE, JR., P.F. E M.K.PATTERSON,JR., Ed. Tissue Culture:Methods and Applications, New York. Academic Press, p.703-709. 
WHITE, P.R., 1946.Cultivation of animal tissues "in vitro" in nutrients of precisely known constitution. Growth, 10:231-289.

WHITESIDE, J.P. e R.E.SPIER, 1981. The scale-up from 0.1 to 100 litres of a unit process system based on $3 \mathrm{~mm}$ diameter glass spheres for the production of four strains of FMoV from BHK monolayer cells. Biotechnology Bioengineering, 23:551-565.

WOOD, W.I., D.J.CAPON, C.S.SIMONSEN, D.L.EATON, J.GITSCHIER, B. KEYT, P.H.SEEBURG, D.H.SMITH, P.HOLLINGSHEAD, K.L. WION; E.DELWART, E.G.D.TUDDENHAM, G.A.VEHAR E R.M.LAWN,1984.Expression of active human factor VIII from recombinant DNA clones. Nature, 312:330-337.

WU, R. e G.H.SATO, 1978. Replacement of serum in cell culture by hormones : a study of hormonal regulation of cell growth and specific gene expression.Journal of Toxicology and Environmental Health, $4: 427-448$.

YAMADA, M. \& K.OLDEN, 1978.Fibronectins - Adhesive glycoproteins of cell surface and blood. Nature, 275:179-184.

YOUNGER, J.,1954. Monolayer tissue cultures, 1 - Preparation and standardisation of suspension of trypsin-dispersed monkey Kidney cells. Proceedings of the Society for Experimental Biology and Medicine, 85:202-205. 
.103.

ZWERNER, R.K., R.M.COX, J,D.LYNN E R.T.ACTON, 1981, FIVE years perspective of the large-scale growth of mammalian cells in suspension culture. Biotechnology Bioengineering, 23: $2717-2735$. 